\title{
Anhang 3 \\ Johannesevangelium (lykopolitanisch)
}

Kerstin Sänger-Böhm, Matthias H. O. Schulz 



\section{1-51 lac.}

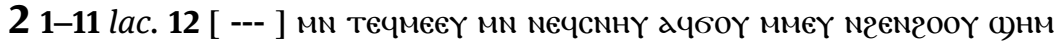

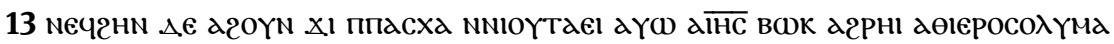

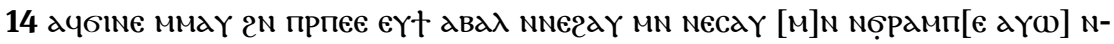

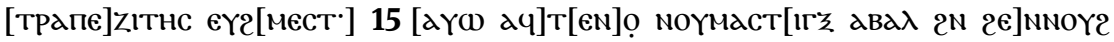

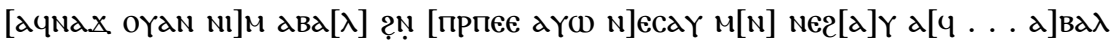

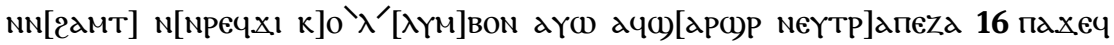

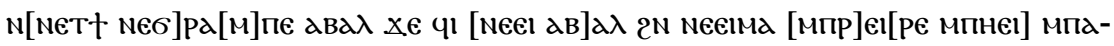

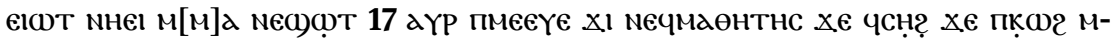

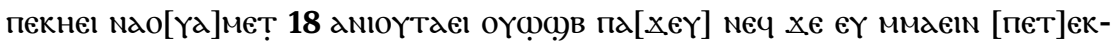

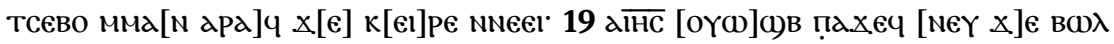

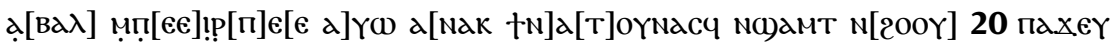

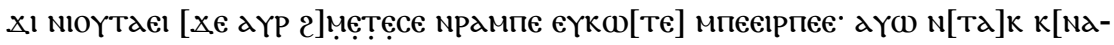

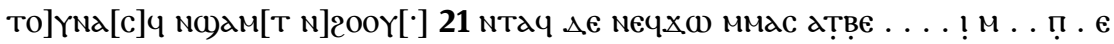

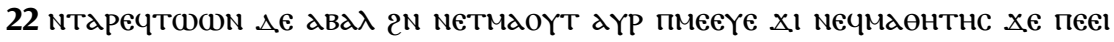
петчх

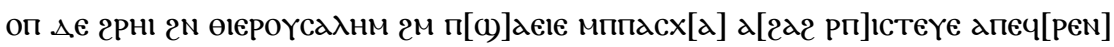

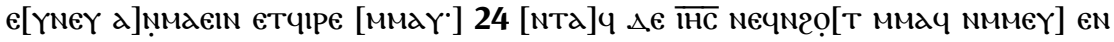

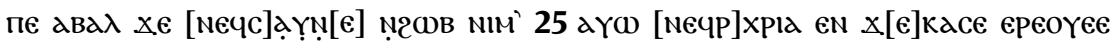

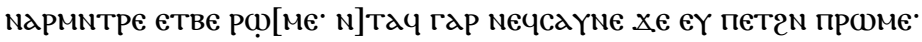

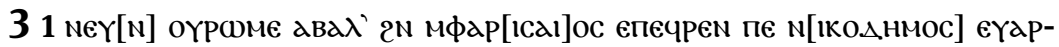

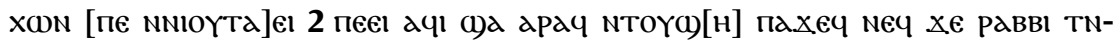

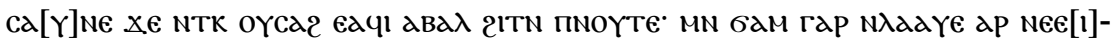

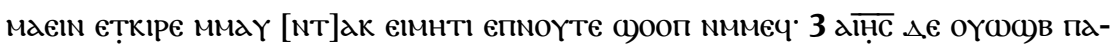

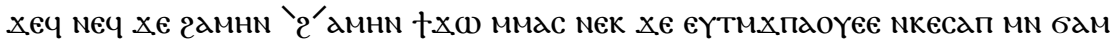

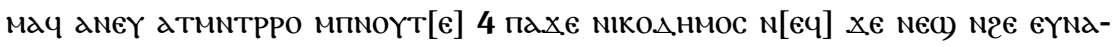

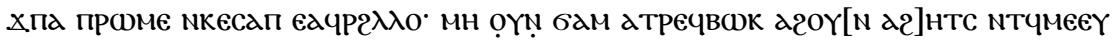

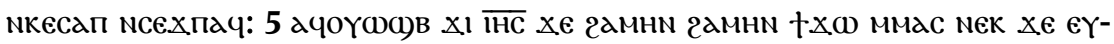

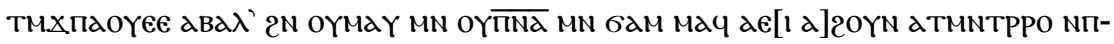

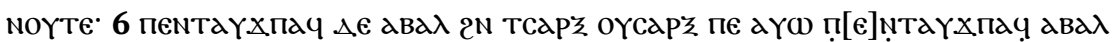

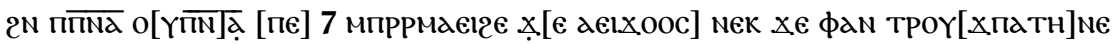

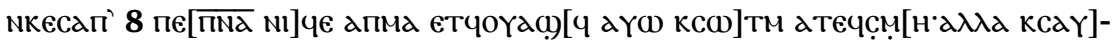

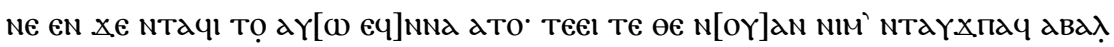

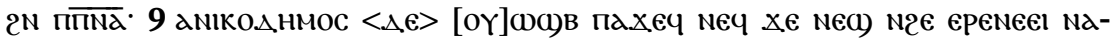

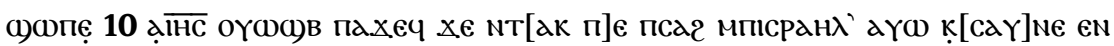

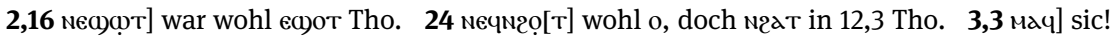

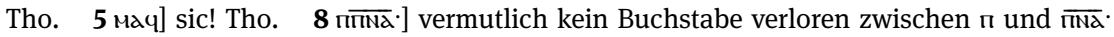

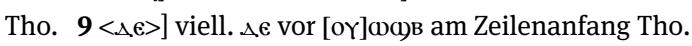




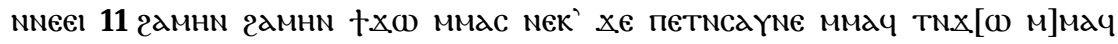

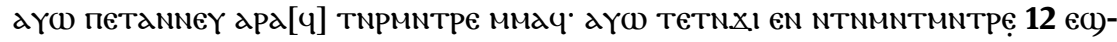

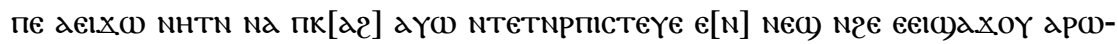

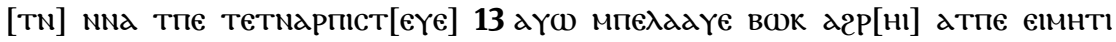

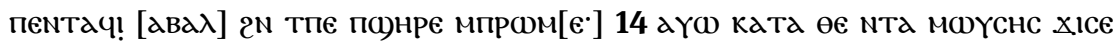

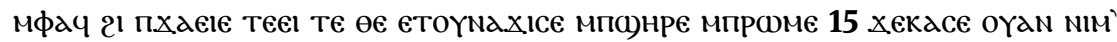

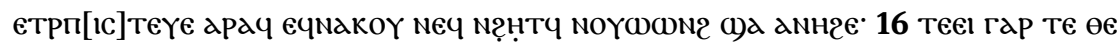

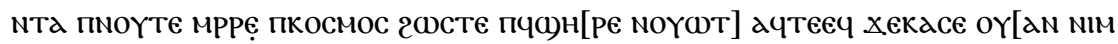

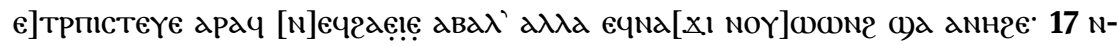

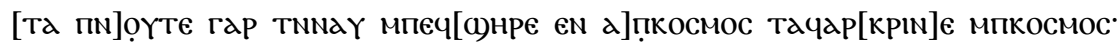

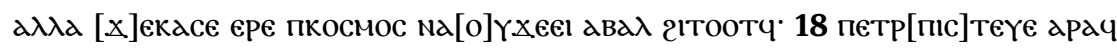

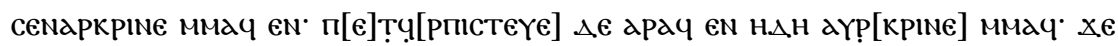

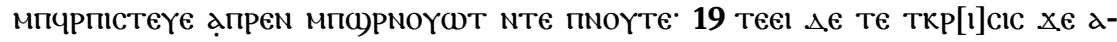

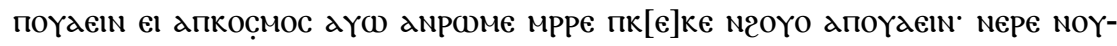

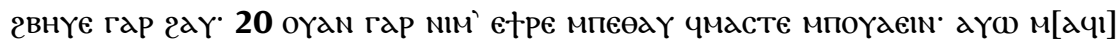

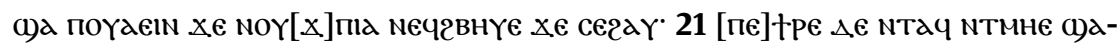
[Pєчl] aпоү'd' п]оүaein 22-36 lac.

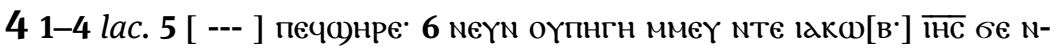

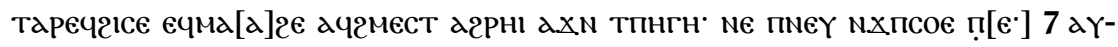

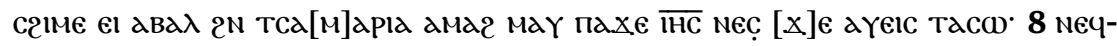

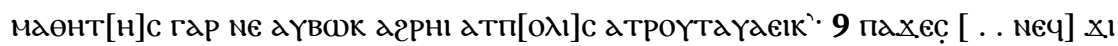

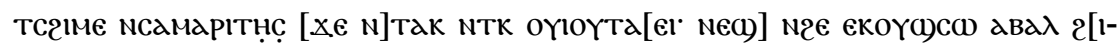

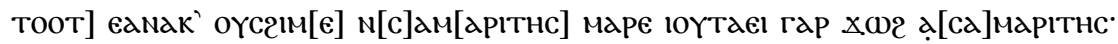

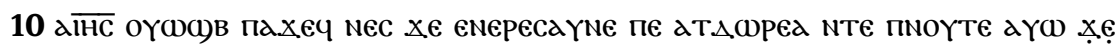

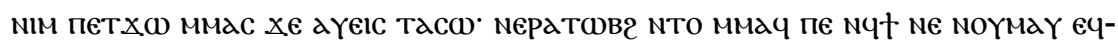

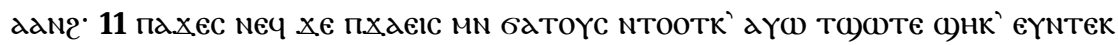

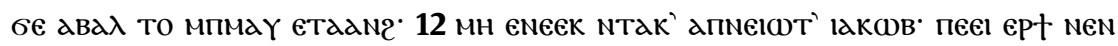

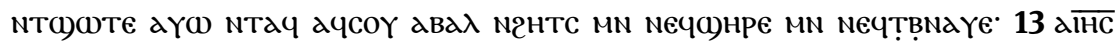

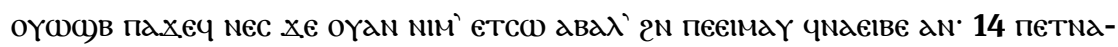

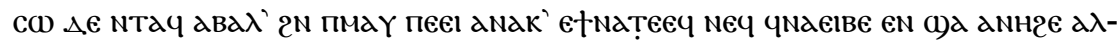

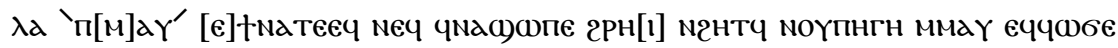

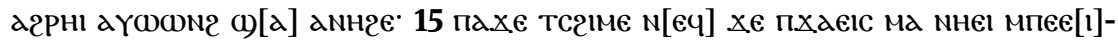

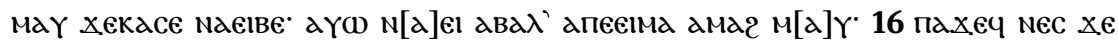

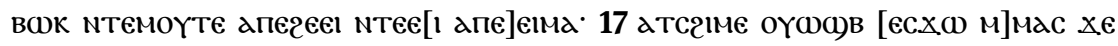

11 петамmeү] sic! Tho. 16 [м]ечгаe!e] nега]

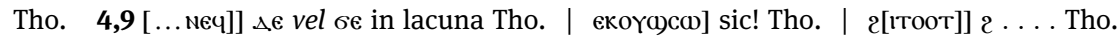
хw2] sic! Tho. 10 mmac] sic!, ne om. Tho. 12 ept] sic! Tho. 


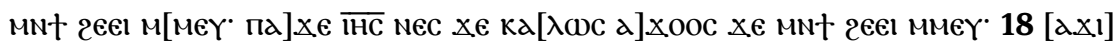

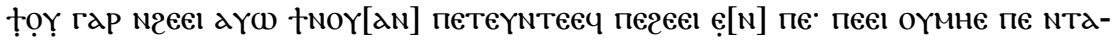

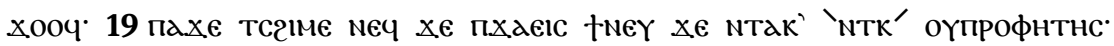

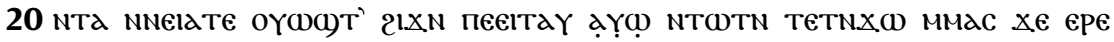

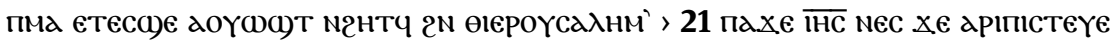

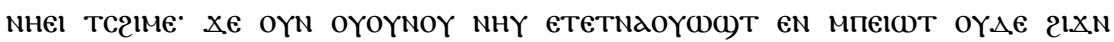

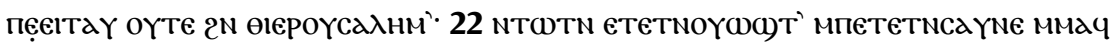

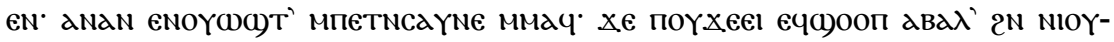

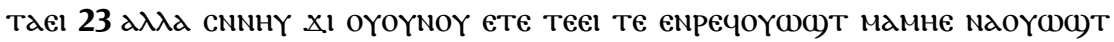

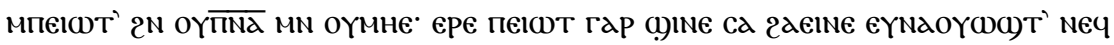

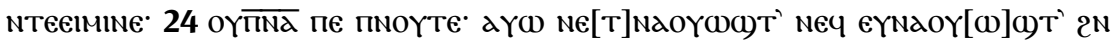

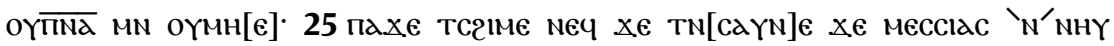

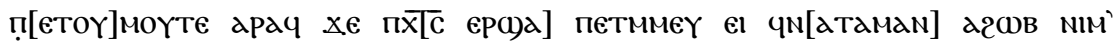

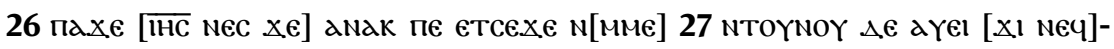

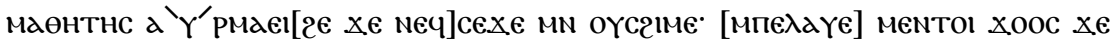

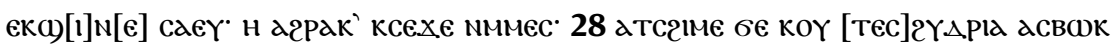

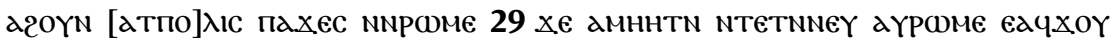

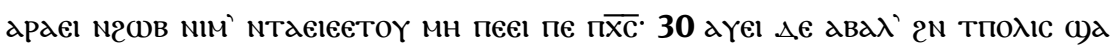

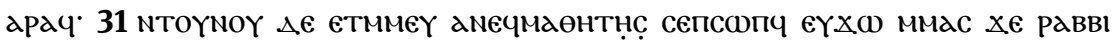

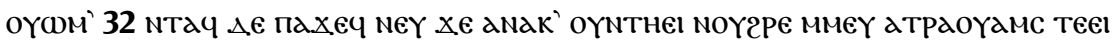

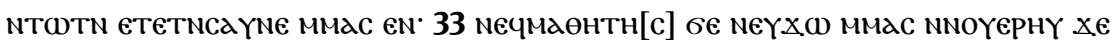

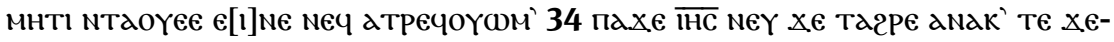

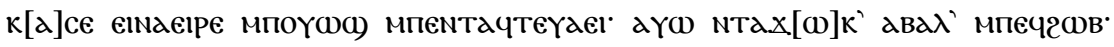

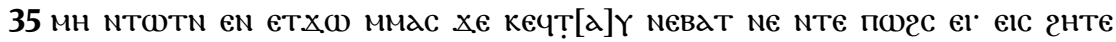

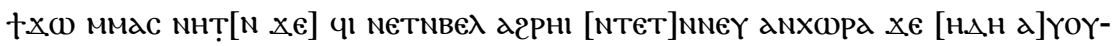

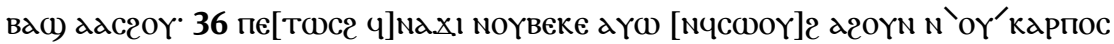

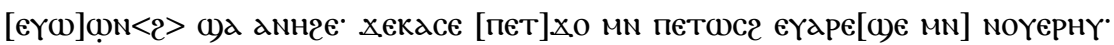

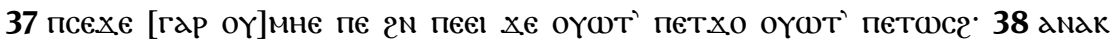

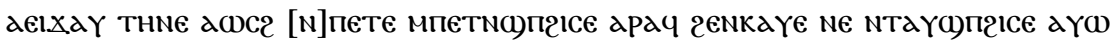

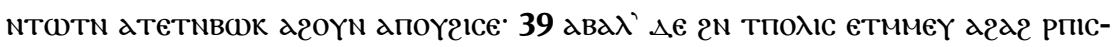

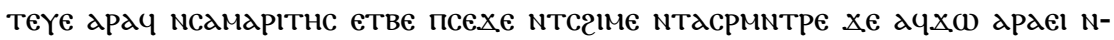

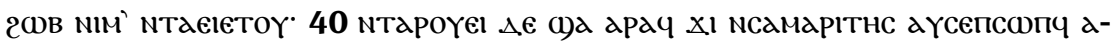

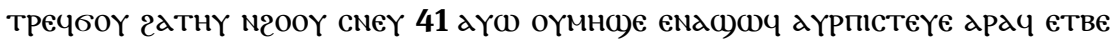

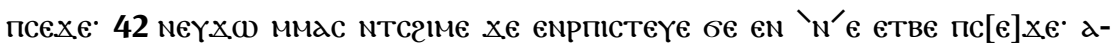

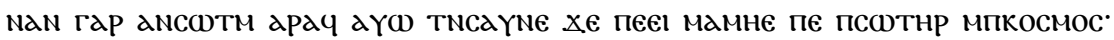

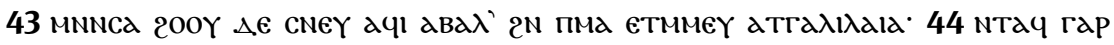

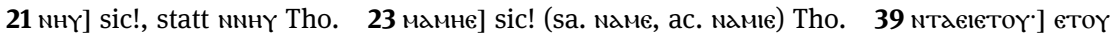
sic! Tho. 


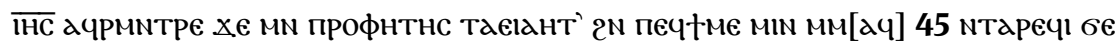

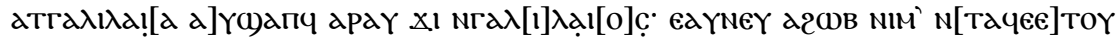

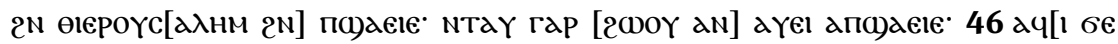

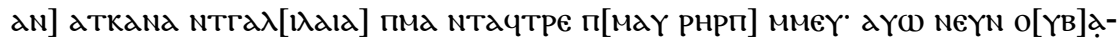

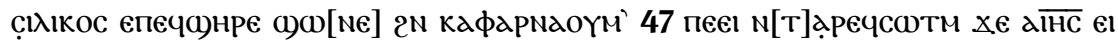

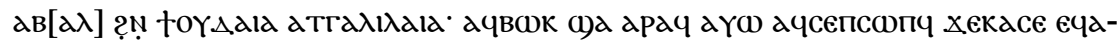

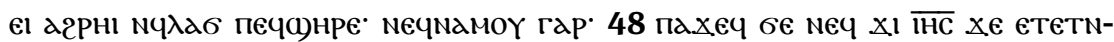

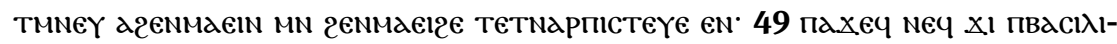

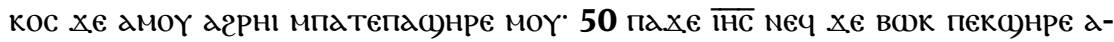

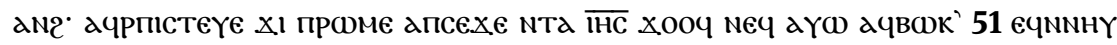

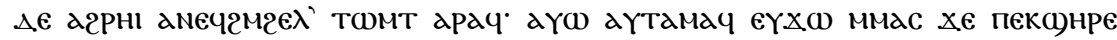

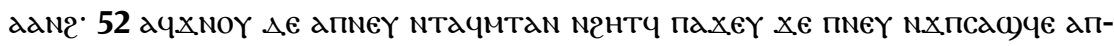

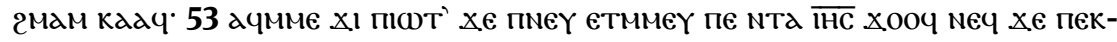

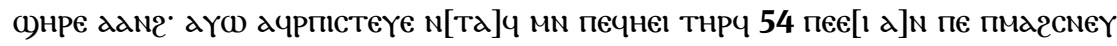

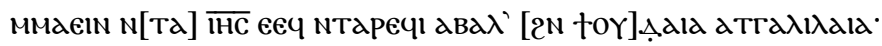

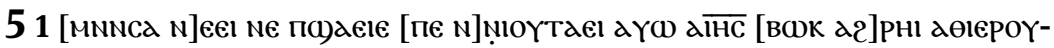

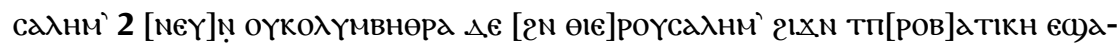

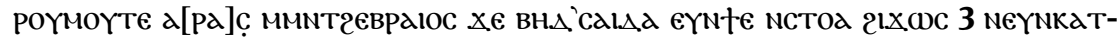

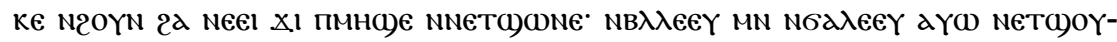

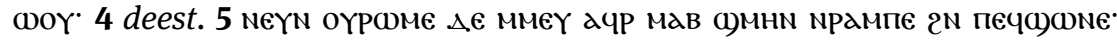

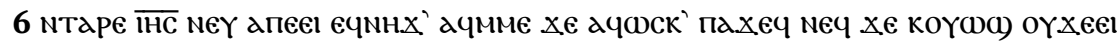

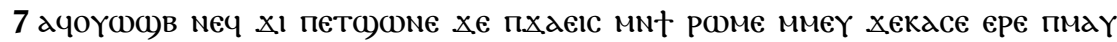

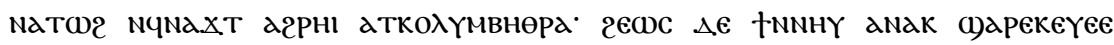

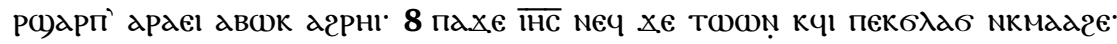

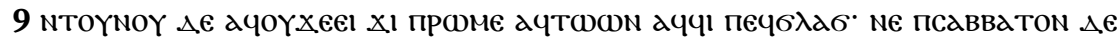

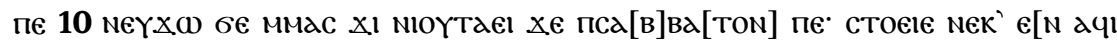

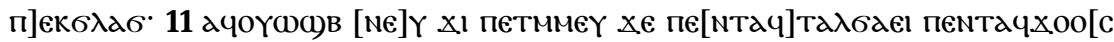

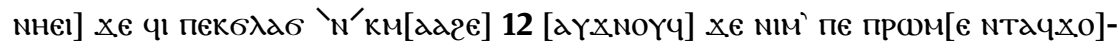

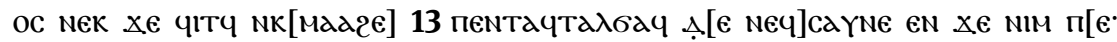
$\overline{\mathrm{lHC}}]$ гар Ne ачсегтч еү[NOYMH]

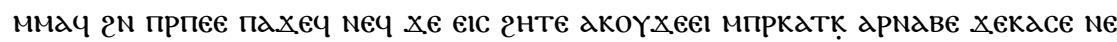

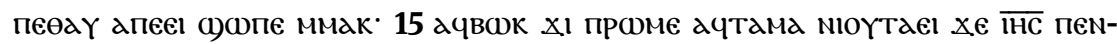

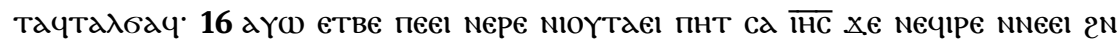

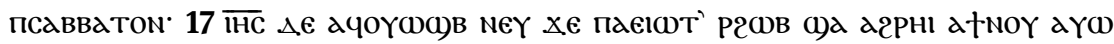

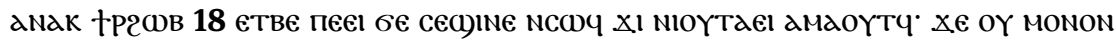

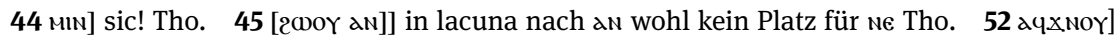

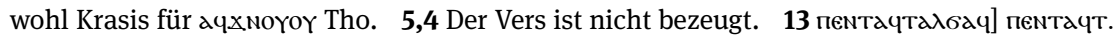
Fehler für пемтаүт. Tho. 


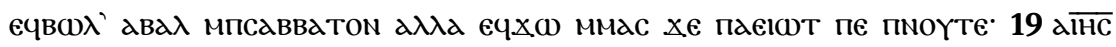

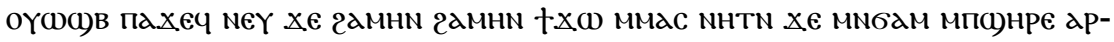

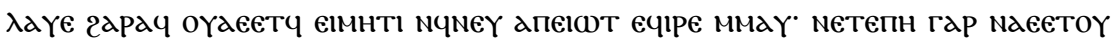

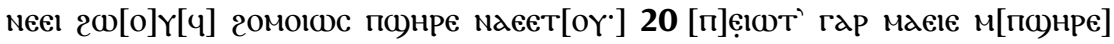

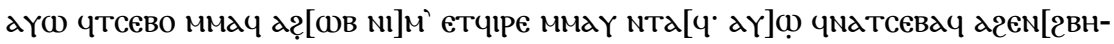

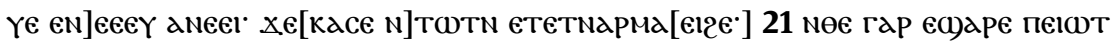

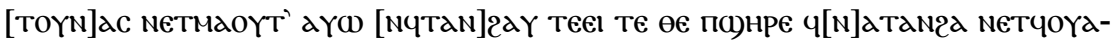

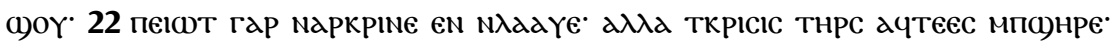

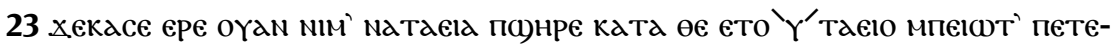

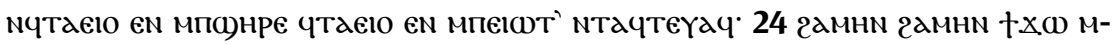

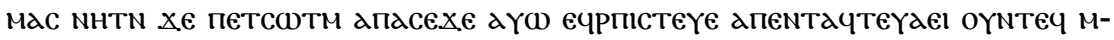
MEY MПDWN

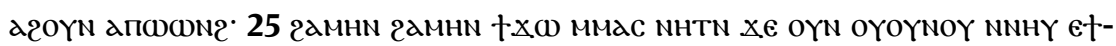

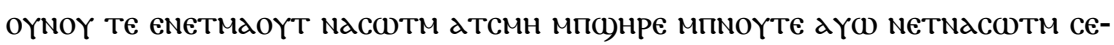

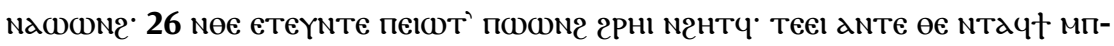

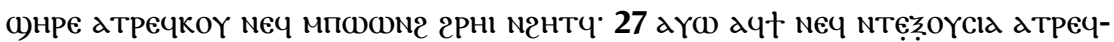

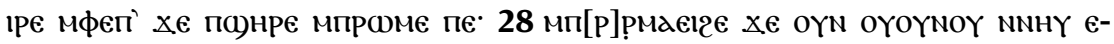

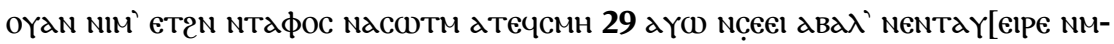

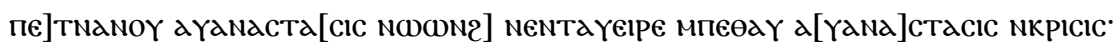

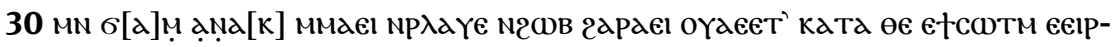

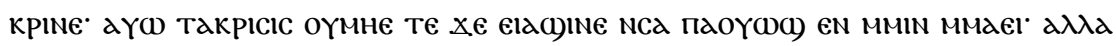

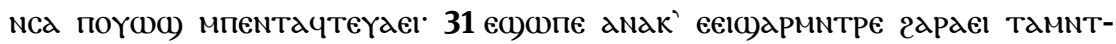

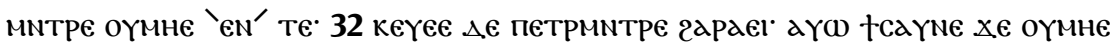

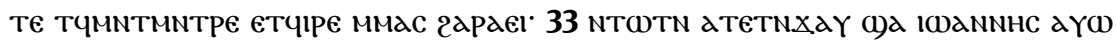

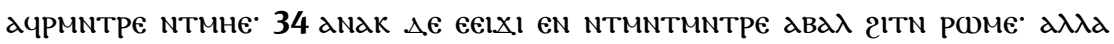

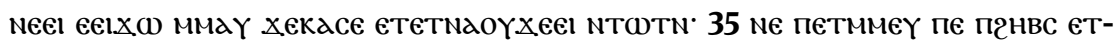

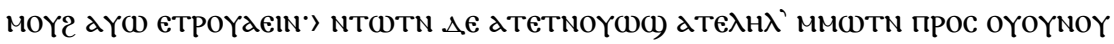

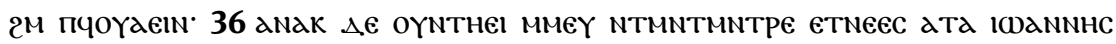

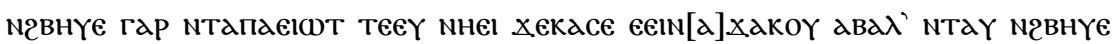

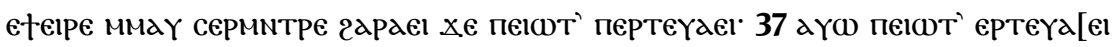

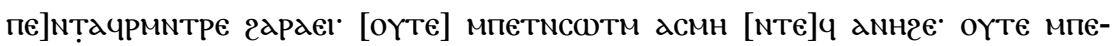

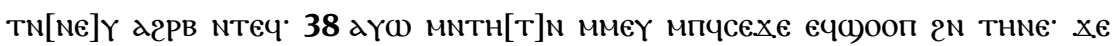

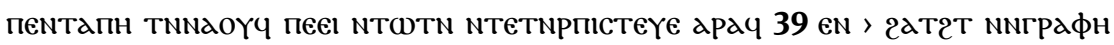

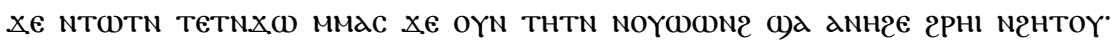

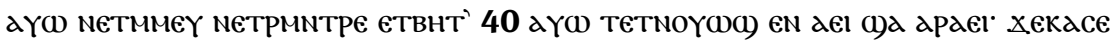

18 ппотте] Text nach ппотте оm. wegen Homoioteleutons; in sa., bo. und gr. vorhanden

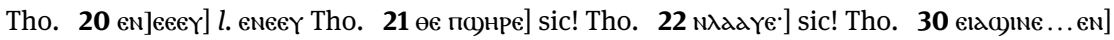
eıda)ıe . . e en ist ein Fehler, in diesem Dialekt mit Negation möglich sind eeıcine (eN) oder Neeic)ine Tho. 


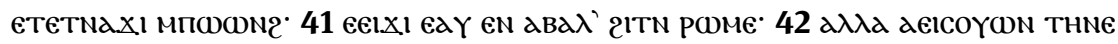

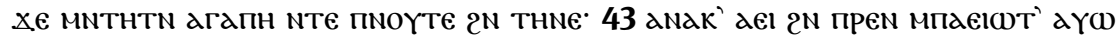

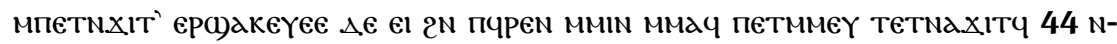

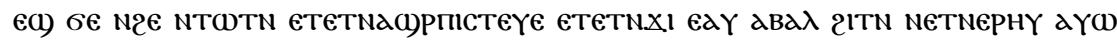

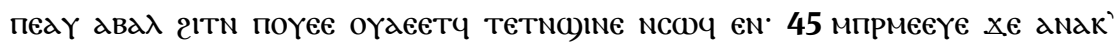

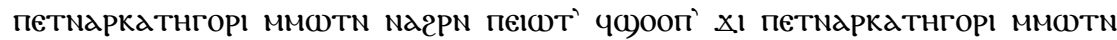

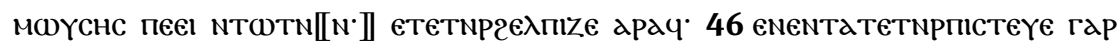

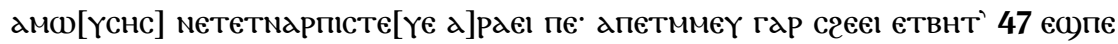
тєт[N]рпістеүє ' $\Delta \epsilon^{\prime}$ ' cexe

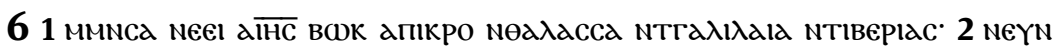
оүмно) еNaC)

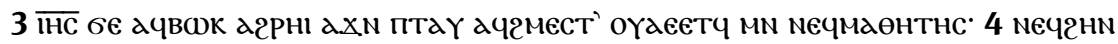

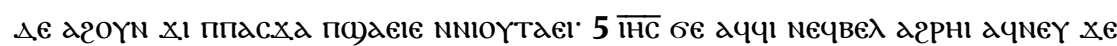

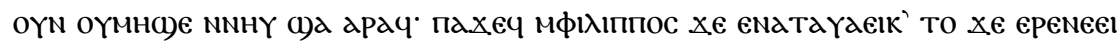

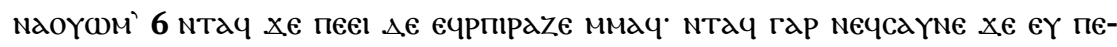

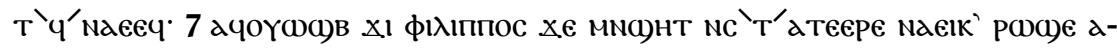

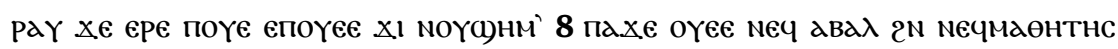

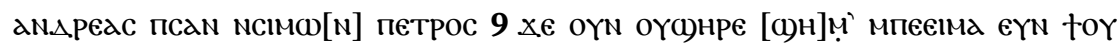

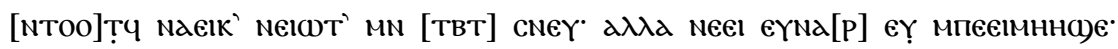

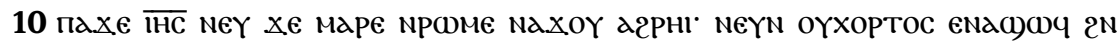

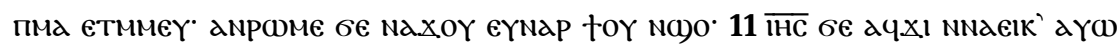

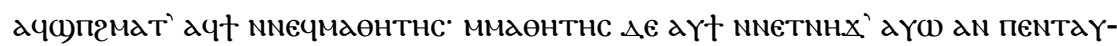

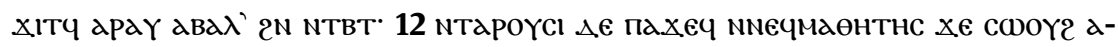

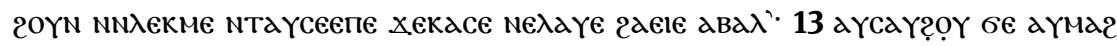

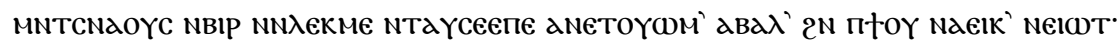

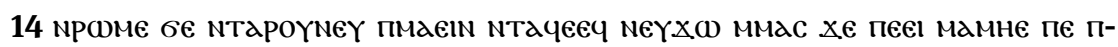

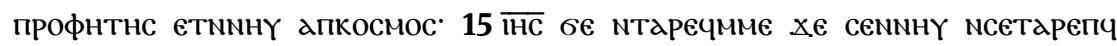

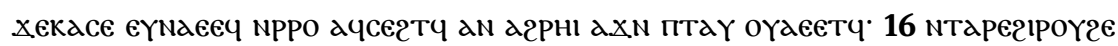

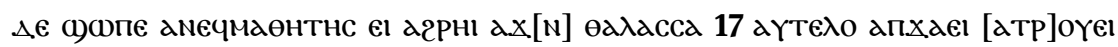

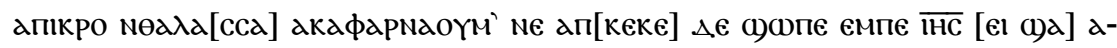

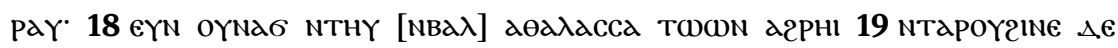

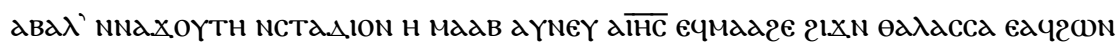

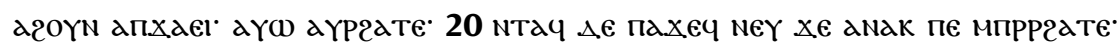

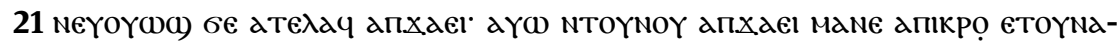

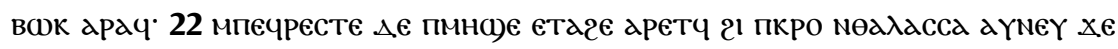

42 дгапн] sic! (ohne Artikel) Tho. 6,4 ппасха] sic! Tho. 9 мпеєімннс)е'] sic! Tho. 16 мтарегіроүє] sic! Tho. 22 пкро] sic!, l. пикро Tho. 


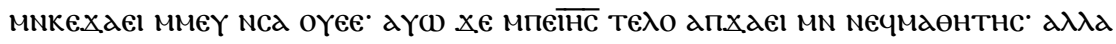

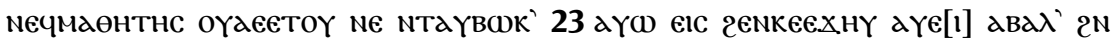

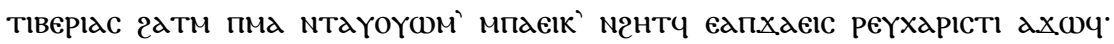

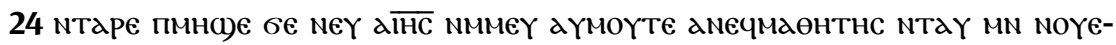

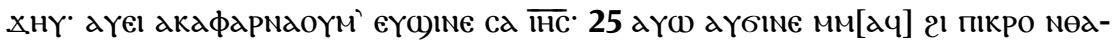

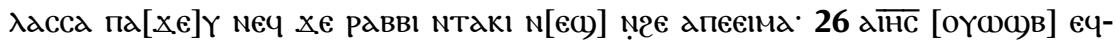

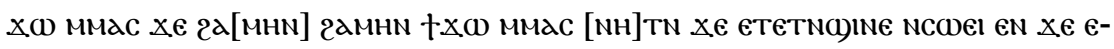

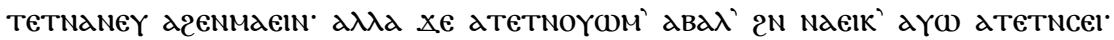

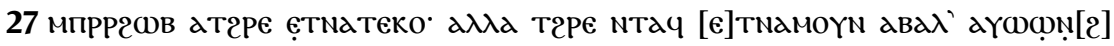

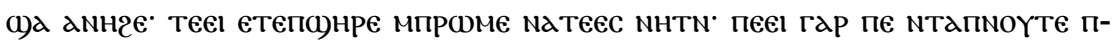

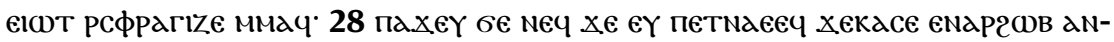

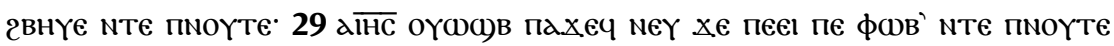

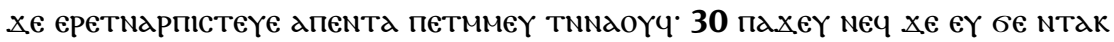

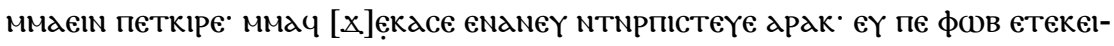

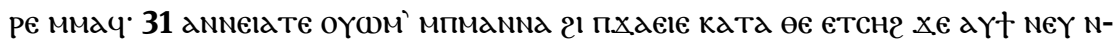

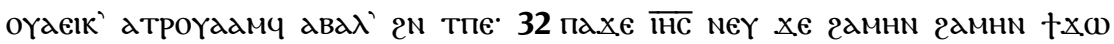

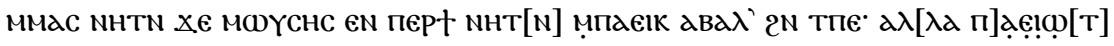

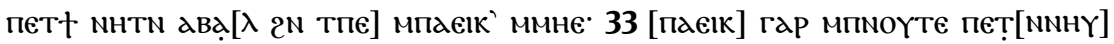

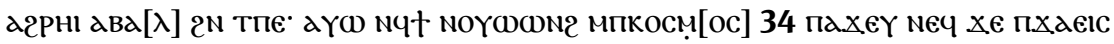

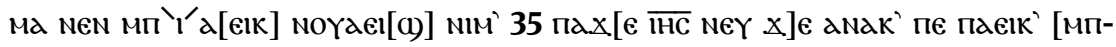

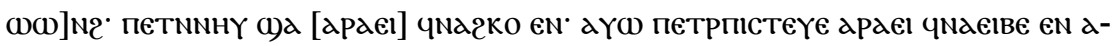

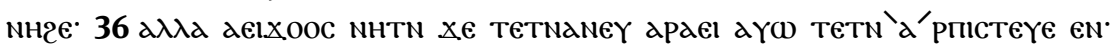

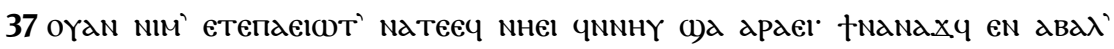

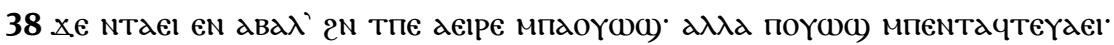

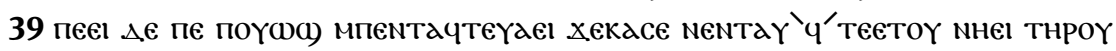

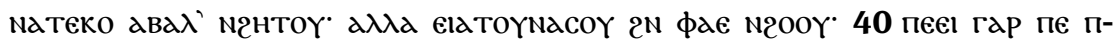

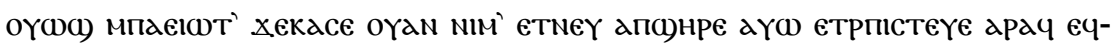

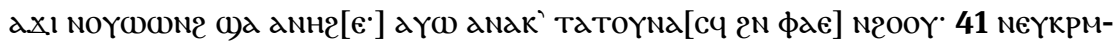

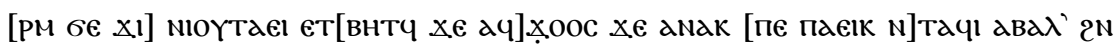

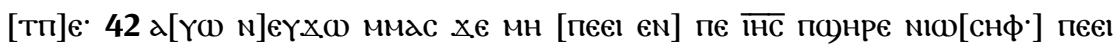

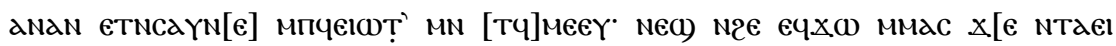

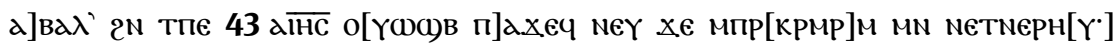

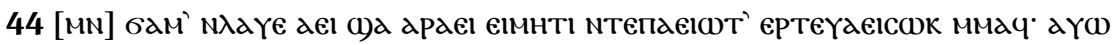

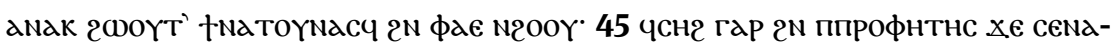

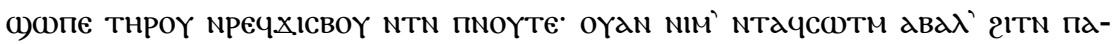

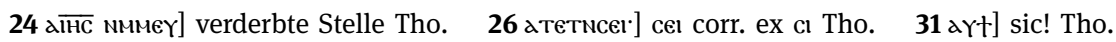

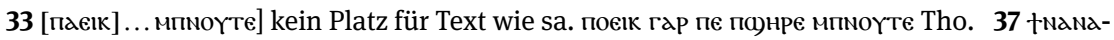

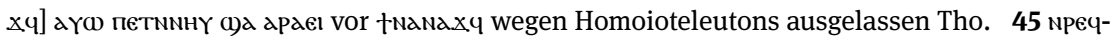
хıсвоү] sic!, своү statt свш Tho. 


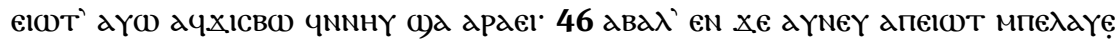

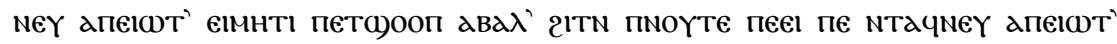

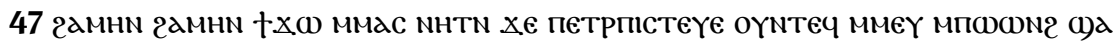

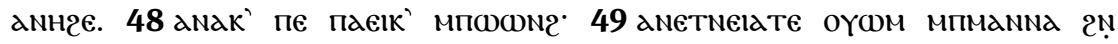

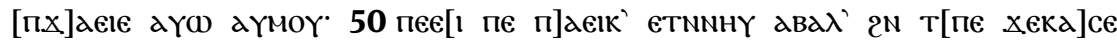

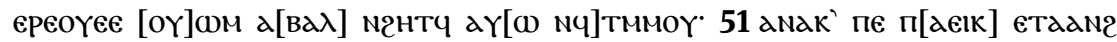

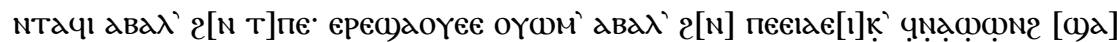

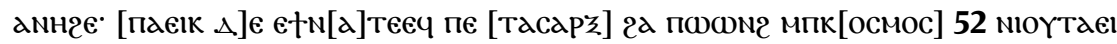

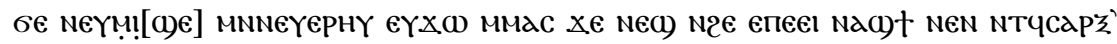

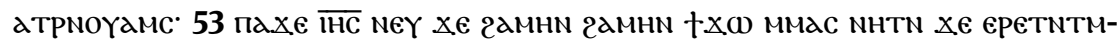

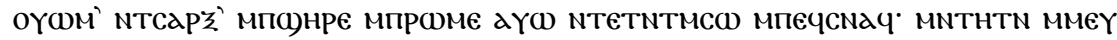

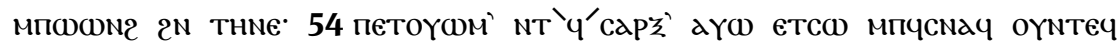

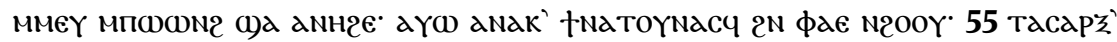

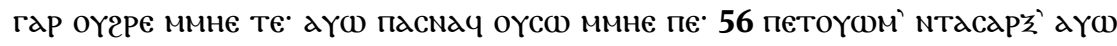

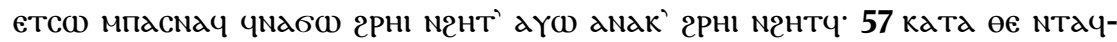

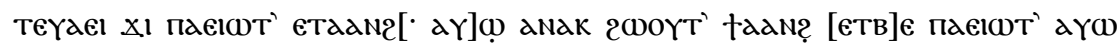

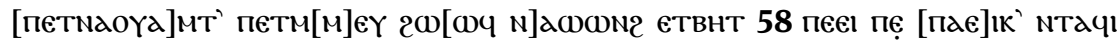

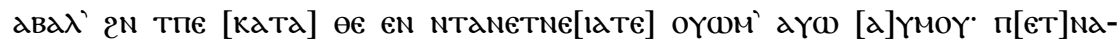

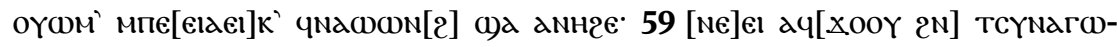

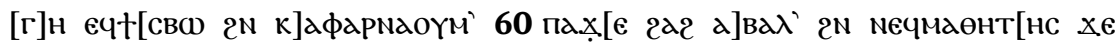

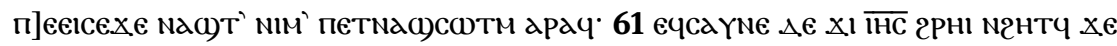

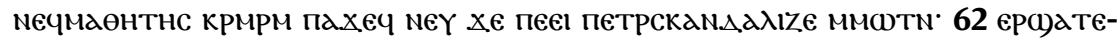

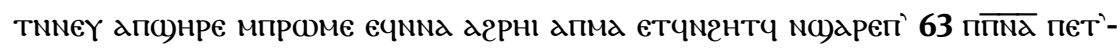

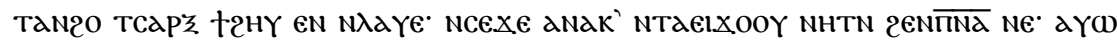

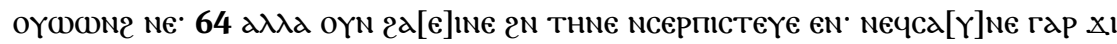

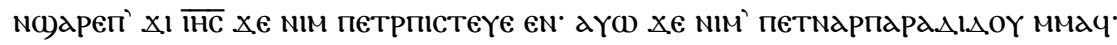

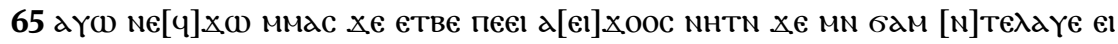

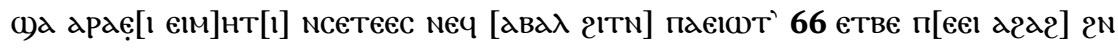

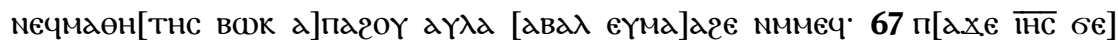

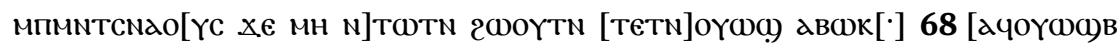

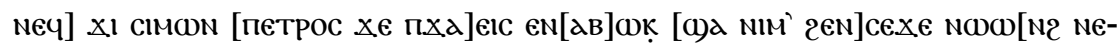

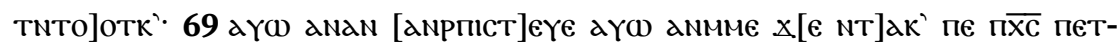

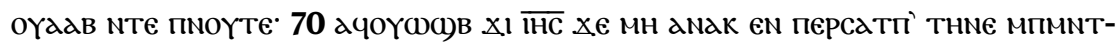

47 амнгє.] Punkt auf der Grundlinie, kein Hochpunkt wie sonst Tho. 50 пєе[1 пе] kein Platz für $\Delta €$ vor $\pi \in$ in der lacuna Tho. 51 [пдєাк $\Delta] \epsilon]$ in der lacuna nur Platz für 6 Buchstaben Tho.

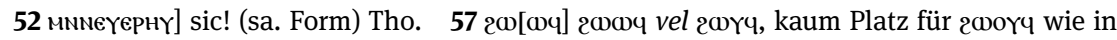
14,12 Tho. 58 [ката]] wohl kein Platz für mehr in der lacuna Tho. 59 ечt [свळ] [свळ vel

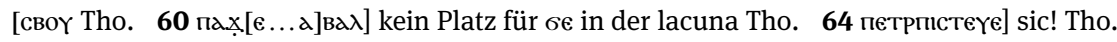

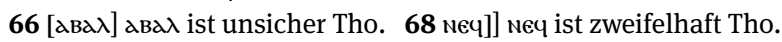




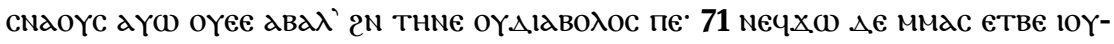

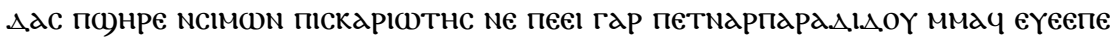

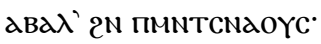

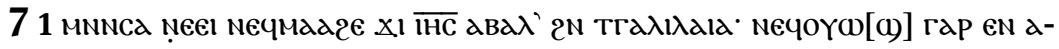

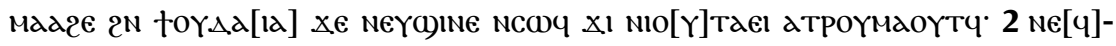

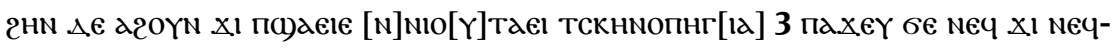
$\mathrm{CNH}[Y]$ X

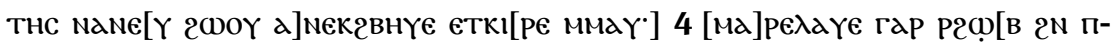

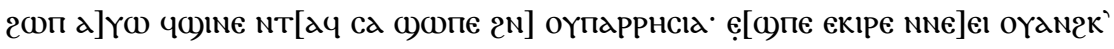

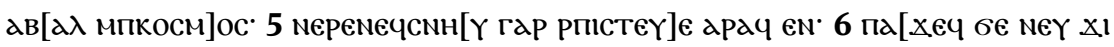

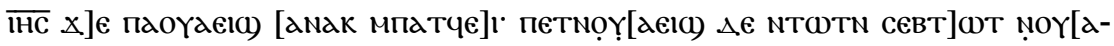

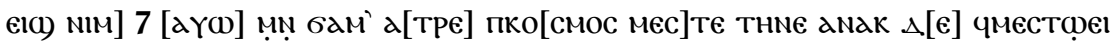

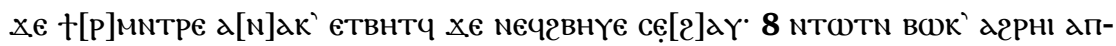

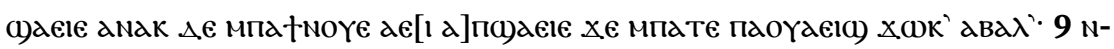

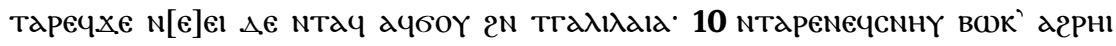

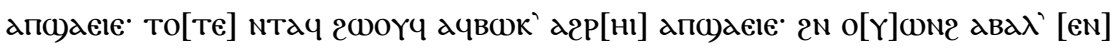

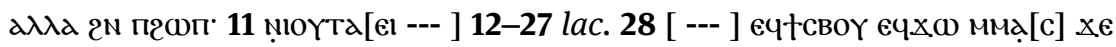

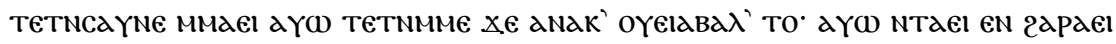

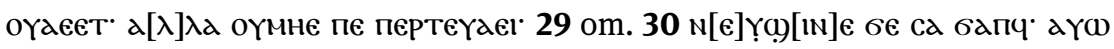

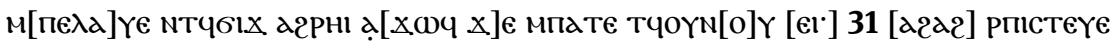

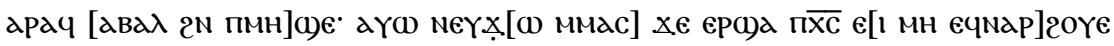

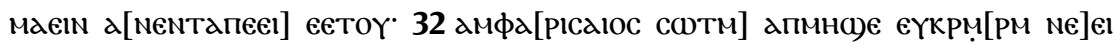

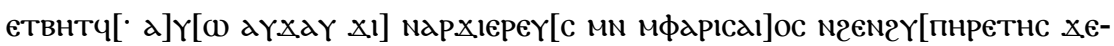

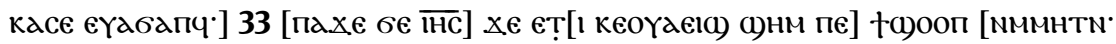

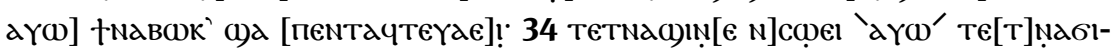

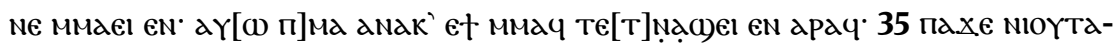

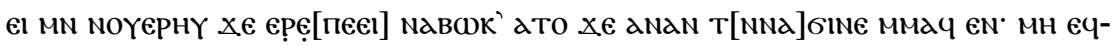

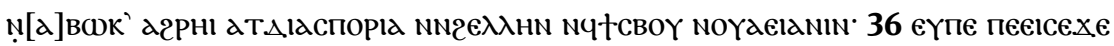

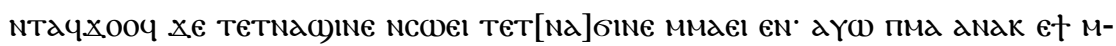

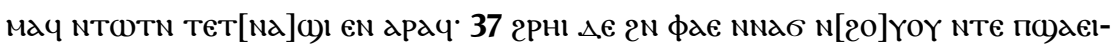

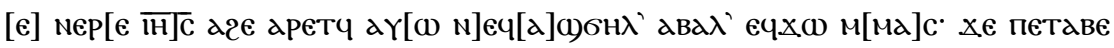

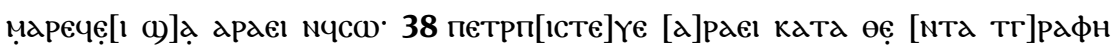

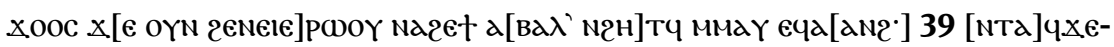

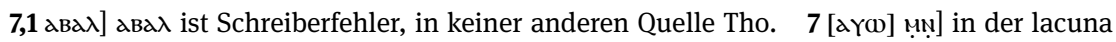
vor ụ̣ Raum für 3 Buchstaben, wohl aүo Tho. 10 nтаремечсnнү] wohl nichts danach am Zeilenende Tho. | о[ү]

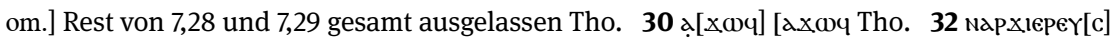

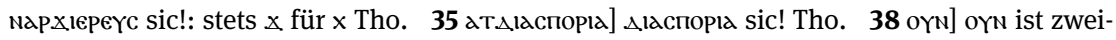
felhaft Tho. 


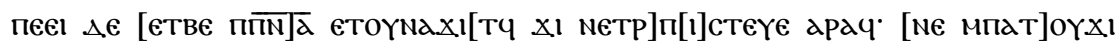

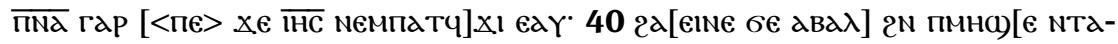

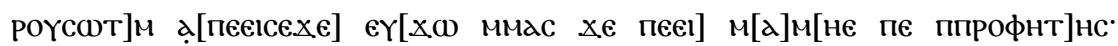

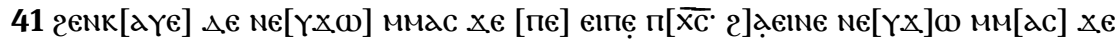

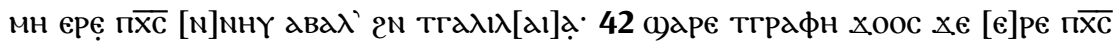

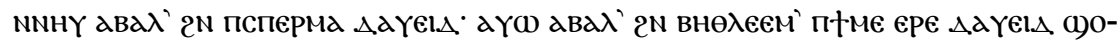

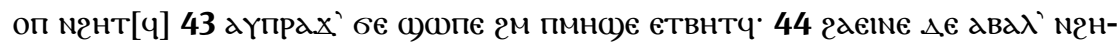

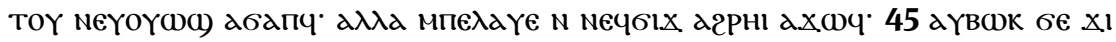

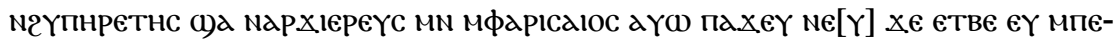

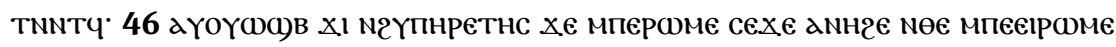

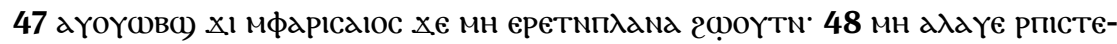

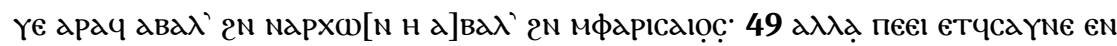

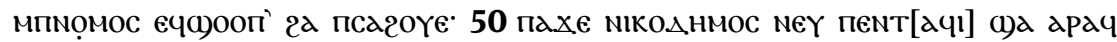

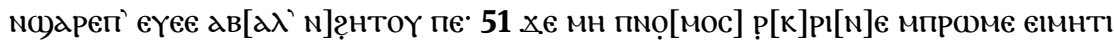

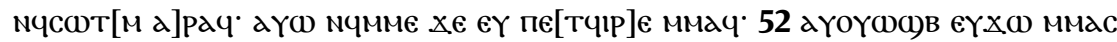

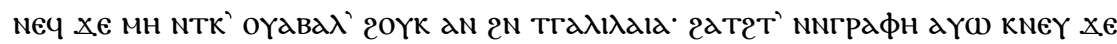

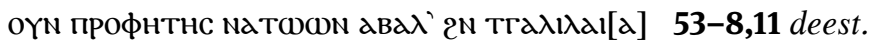

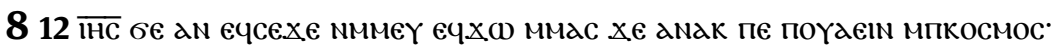

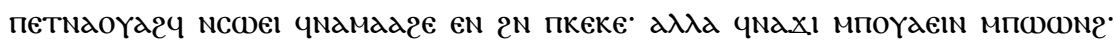

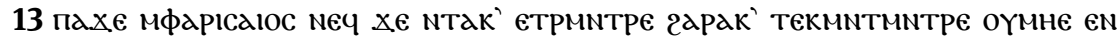

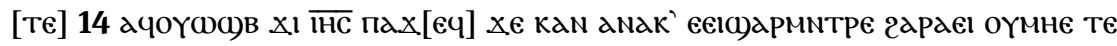

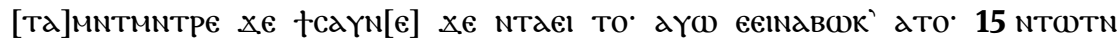

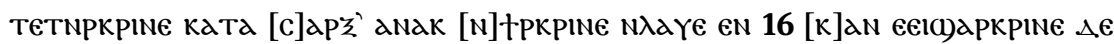

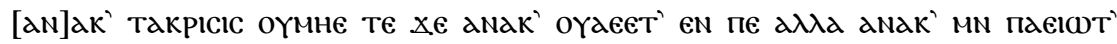

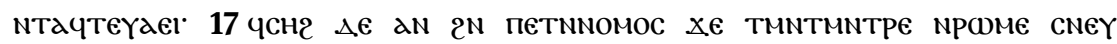

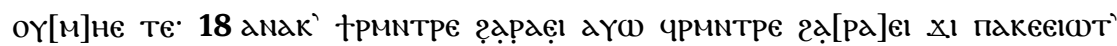

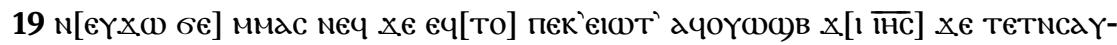

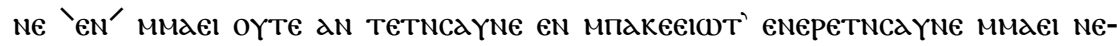

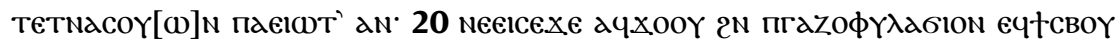

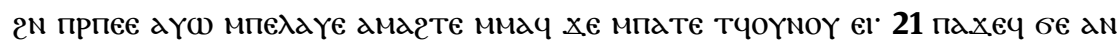

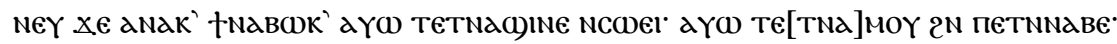

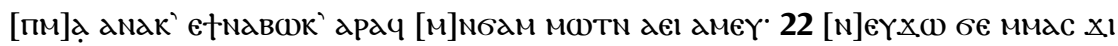

$39[<\pi \epsilon>]$ viell. sollte ein enklitisches пе nach гар eingefügt werden Tho. 40 бе] бe vel $\Delta \epsilon$

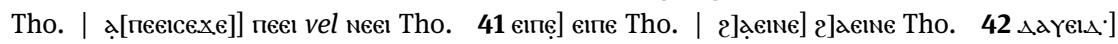

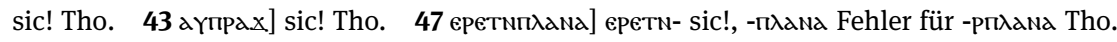

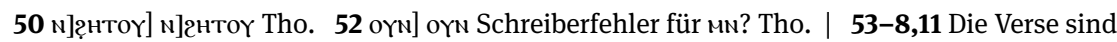
nicht überliefert. 8,12 eqcexe] l. aqcexe Tho. $14 \ldots$... a то ] Versende ausgelassen Tho.

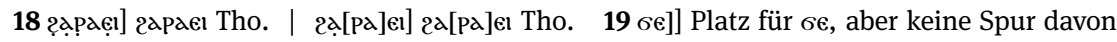
Tho. 21 мळTN] sic! Tho. 


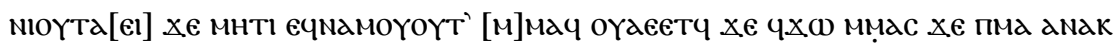

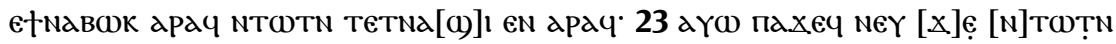

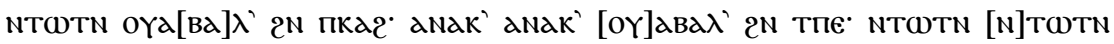

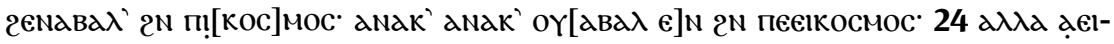

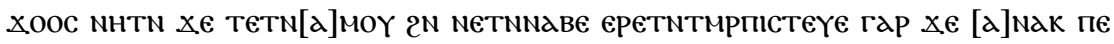

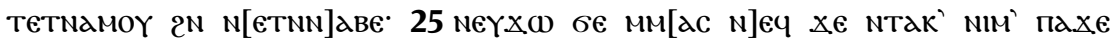

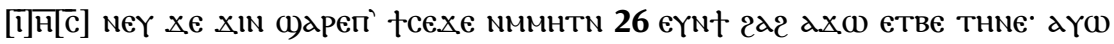

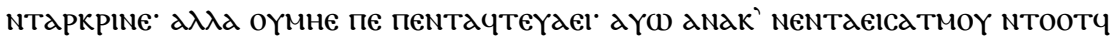

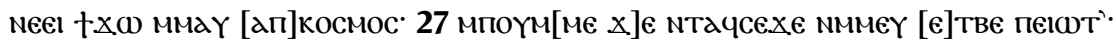

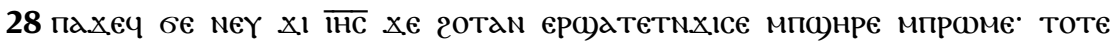

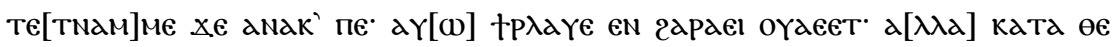

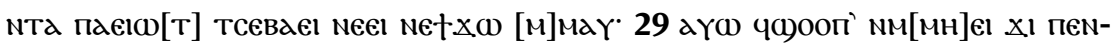

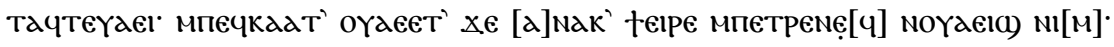

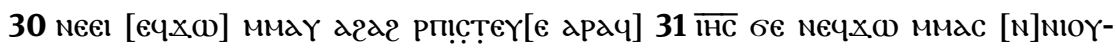

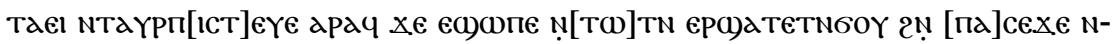

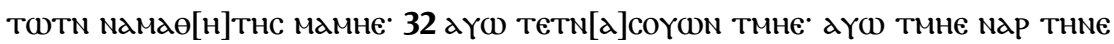

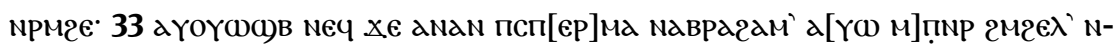

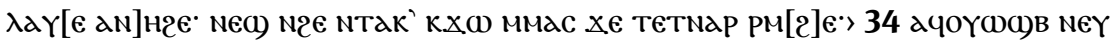

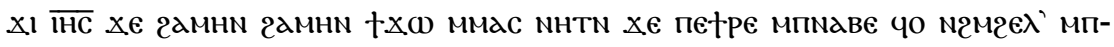

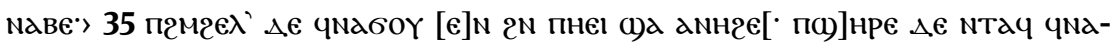

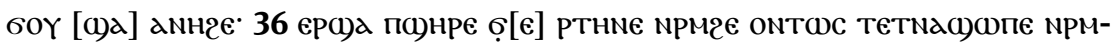

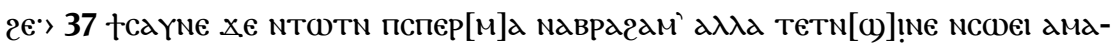

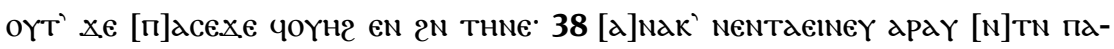

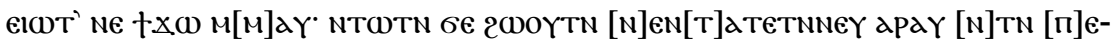

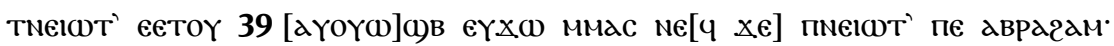

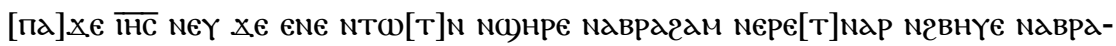

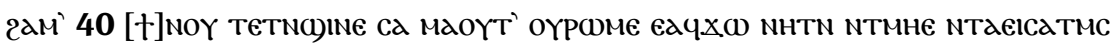

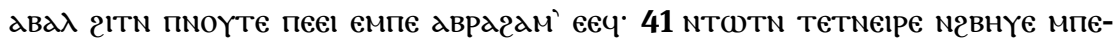

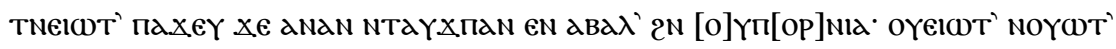

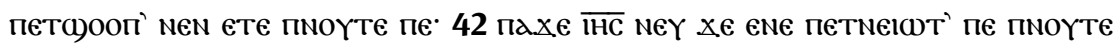

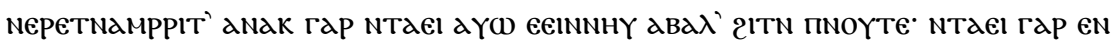

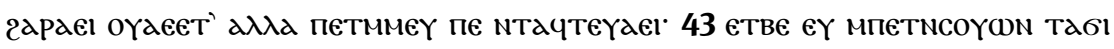

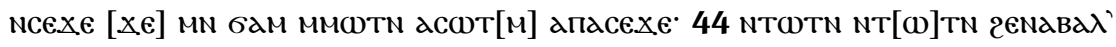

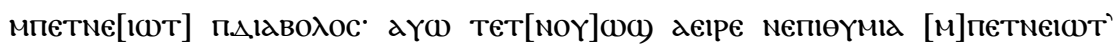

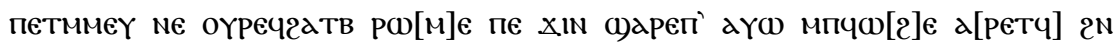
тмне $X[\epsilon]$ м̣̣ [MHє

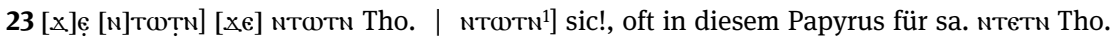
43 [хє]] am Zeilenende wohl nichts nach cexe Tho. 44 мṇ] мn Tho. 


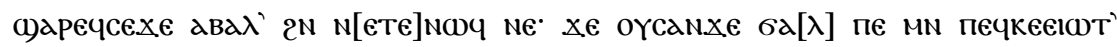

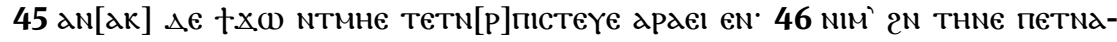

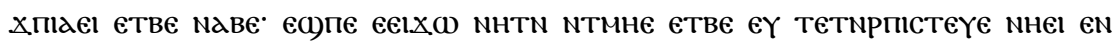

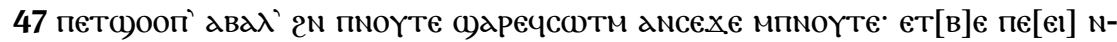

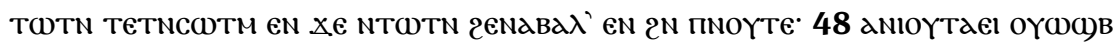

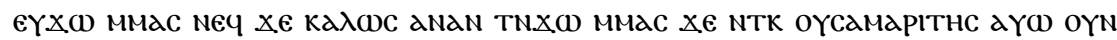

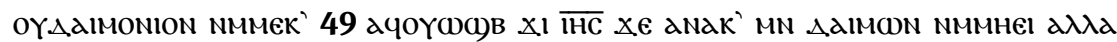

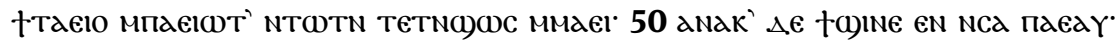

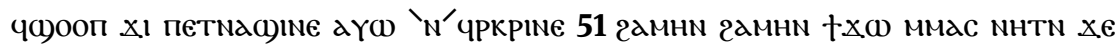

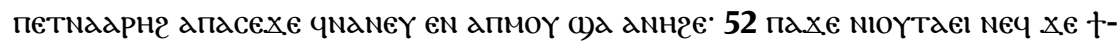

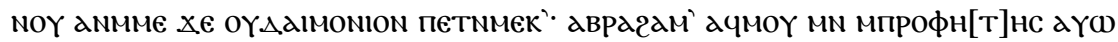

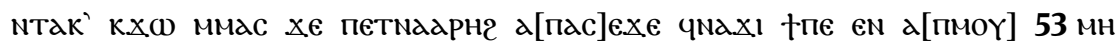

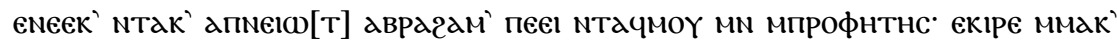

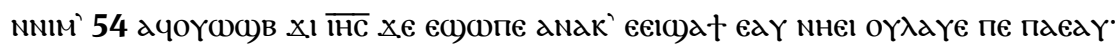

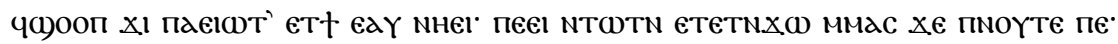

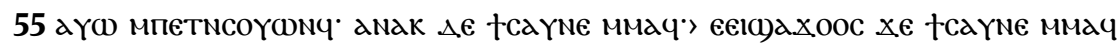
en †NaC)

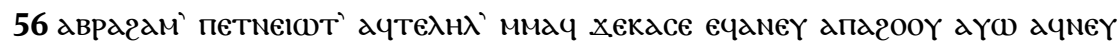

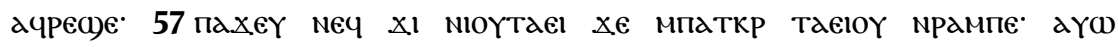

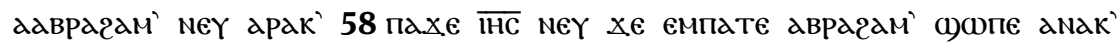

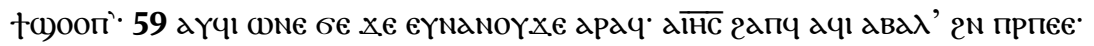

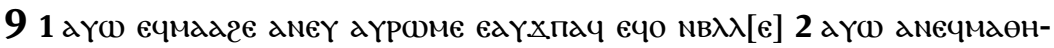

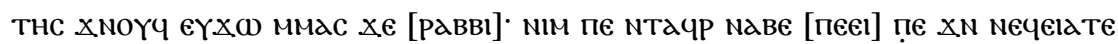

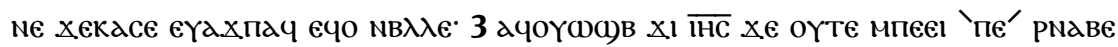

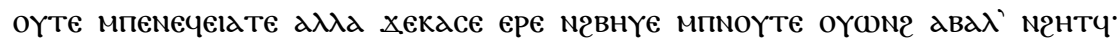
4 со)

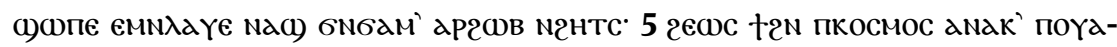

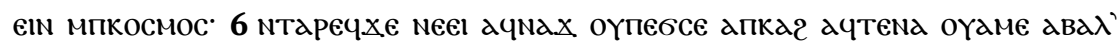

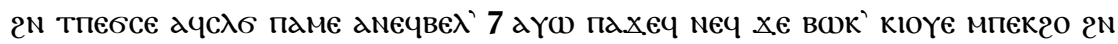

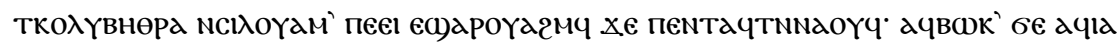

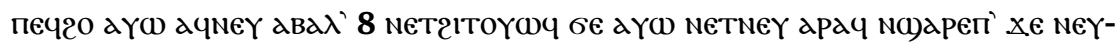

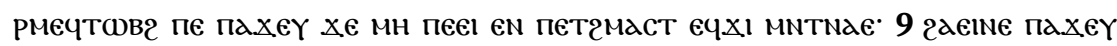

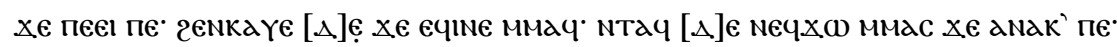

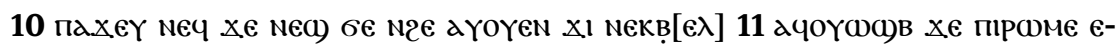

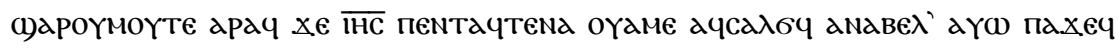

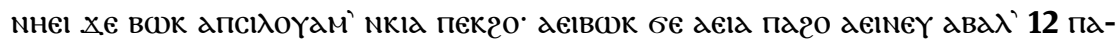

9,7 кіоүе] sic! Tho. | тколүвнөра] sic! Tho. | есдароүагмч] l. есрароүоүдгмч Tho. 8 петгмаст] sic! Tho. 


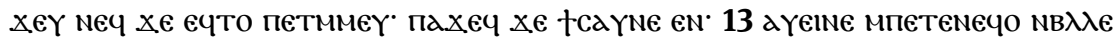

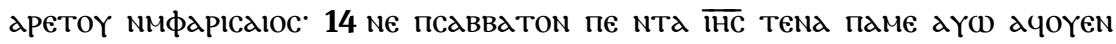

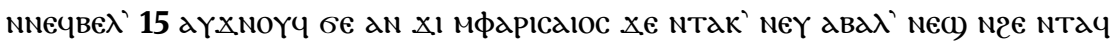

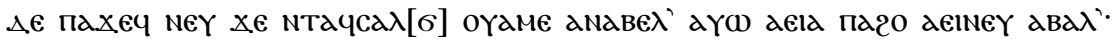

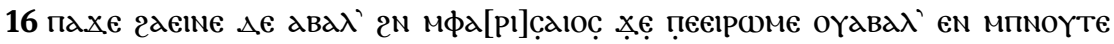

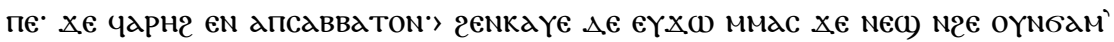

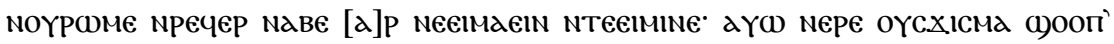

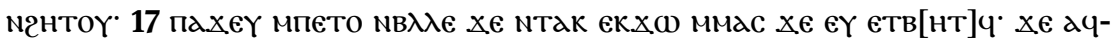

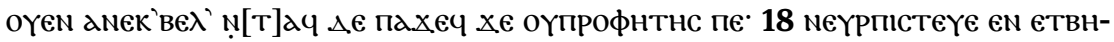

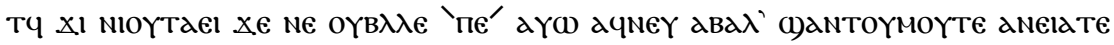

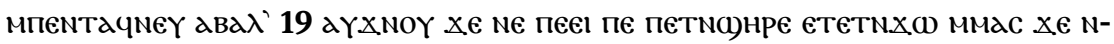

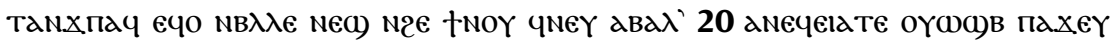

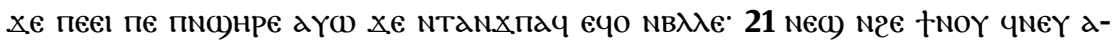

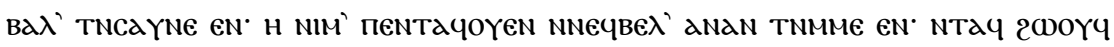

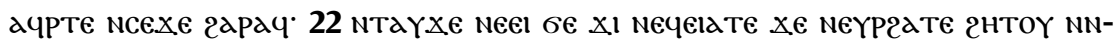

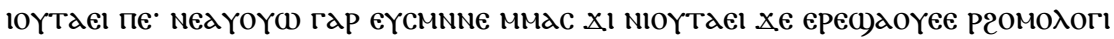

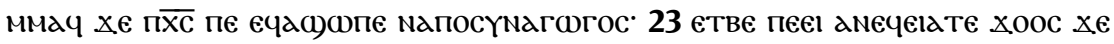

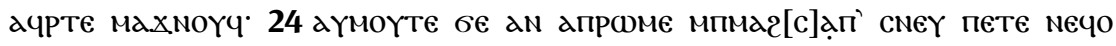

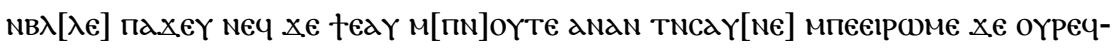

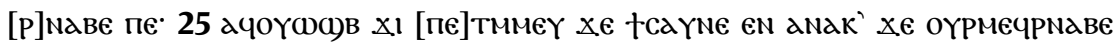

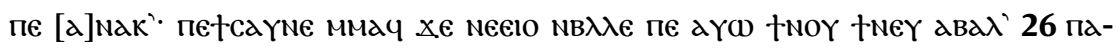

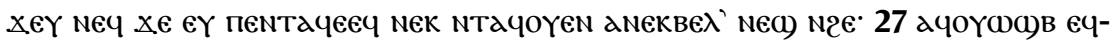

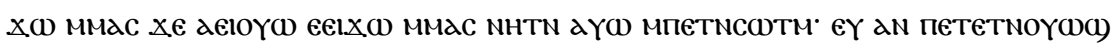

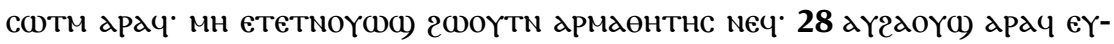

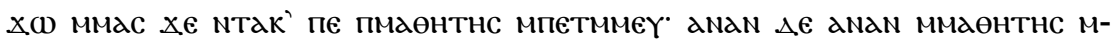

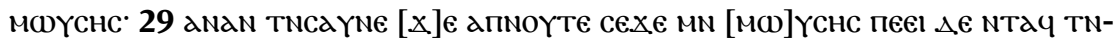

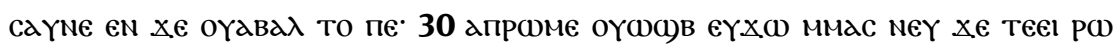

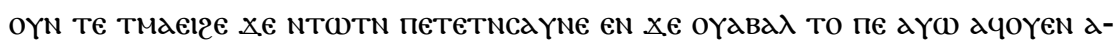

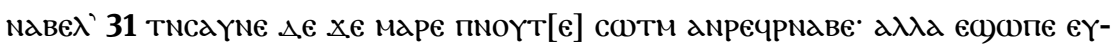

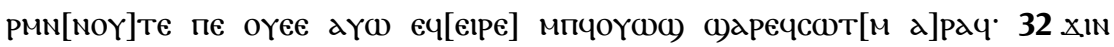

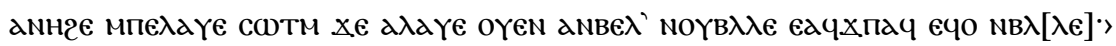

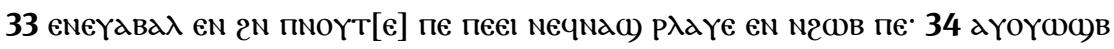

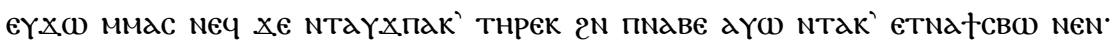

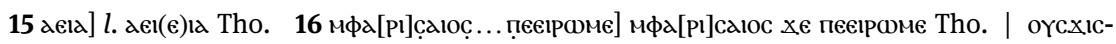
ma] sic! Tho. 19 aүхпоү] l. аүхмоүоү Tho. | ме] l. еме Tho. 22 меүргате гнтоү] distinkte Punkte über $\mathrm{e}$ in гате́ und zweitem (senkrechtem) Strich des н in әнтог (cod.), Bedeutung unklar Tho. | еүсмnne] sic! Tho. 24 мпмаг[с]ап] мпмаг[c]ап Tho. 25 оүрмечрнаве] о्үрмечрмаве Tho. | $[$ [а]мак.] davor oүa ausgelassen Tho. 32 едухпау] sic!, l. еаүхпау Tho. 34 тнрек] sic! Tho. 


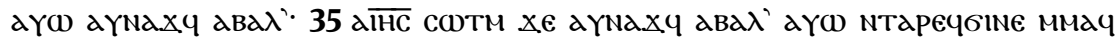
пахеч меч хе аріпістеүе апо)нре мпрбме 36 пахеч хе пхаєІс мім пє

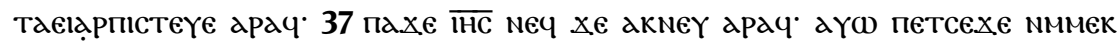

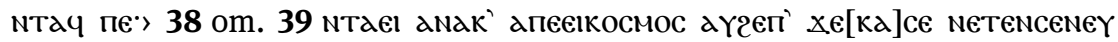

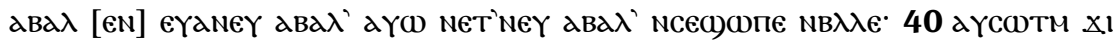

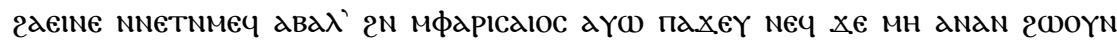

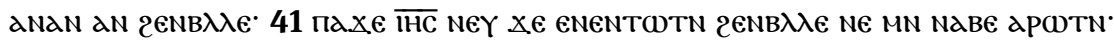

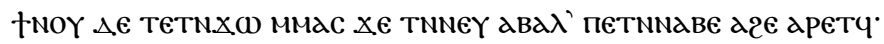

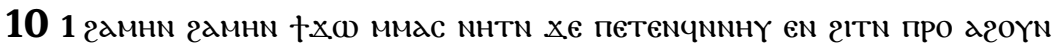

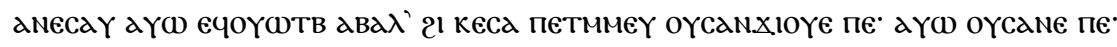

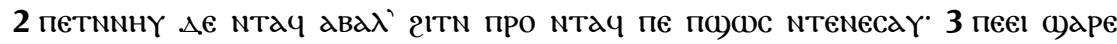

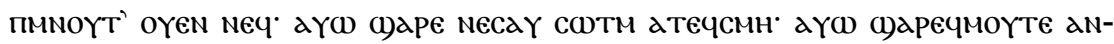

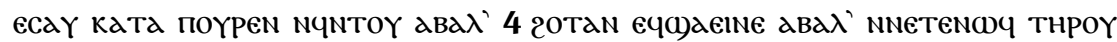

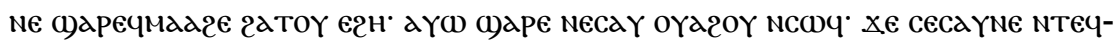

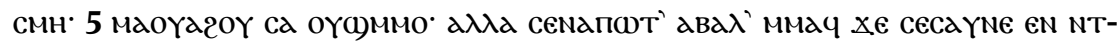

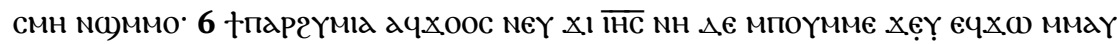

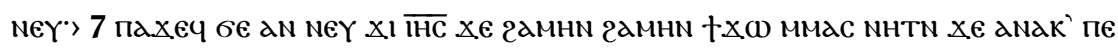

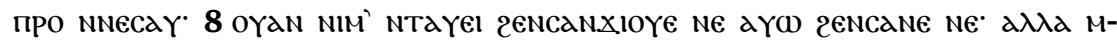

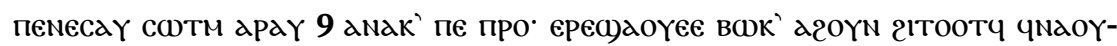

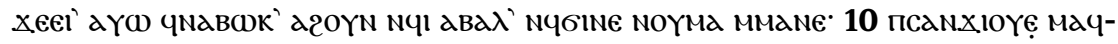

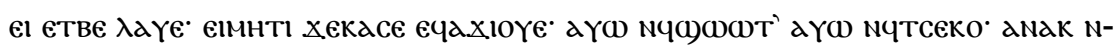

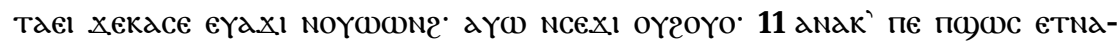

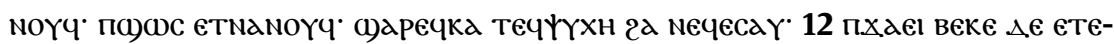

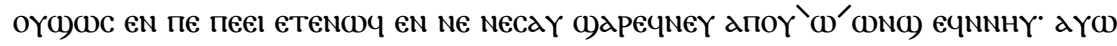

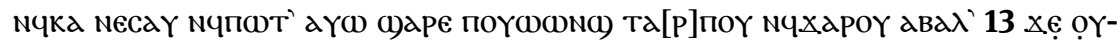

37 пє] ] се> (Anm.: „,e an interesting survival of the O. Eg. st.“) Tho.; Glosse im Buch: „,૯૯>> п JEA 13/83 - ÄZ 63/155“ 39 ntaєl] Beginn von 9,39 om.; l. nтגelel Tho. 40 nnєтnмeq] l. nneтмммеч Tho. | $\mathrm{aN}]$ dN ist stat. constr. zu andN, aber viel eher Fehler und zu tilgen Tho.

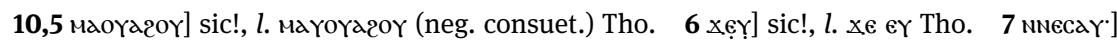

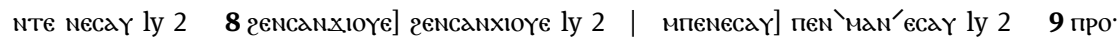

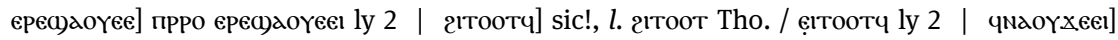

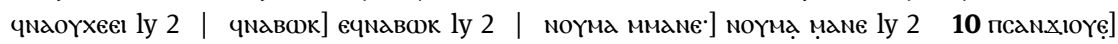

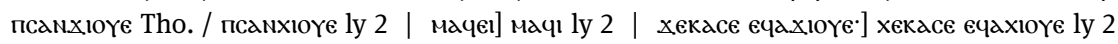

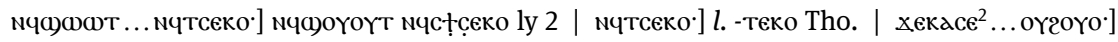

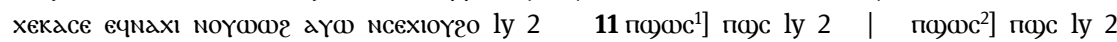

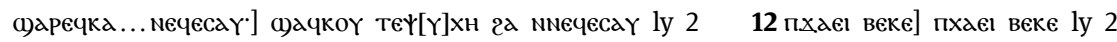

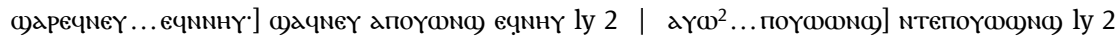

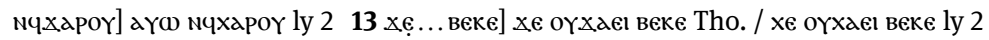




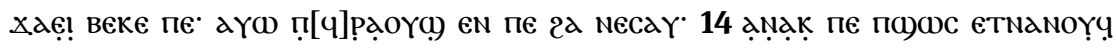

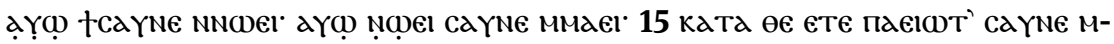

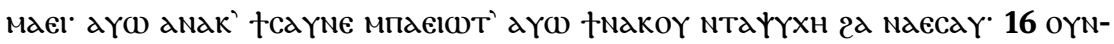

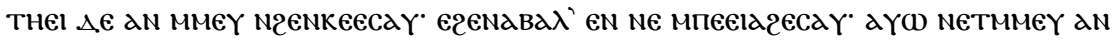

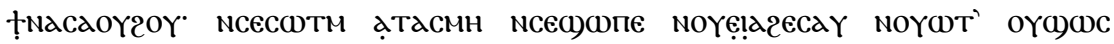

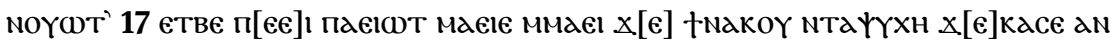

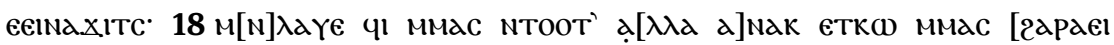

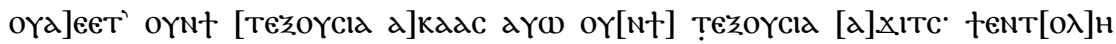

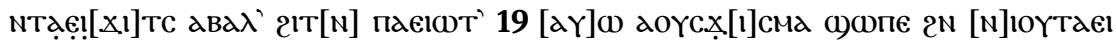

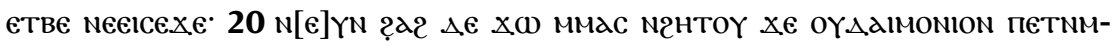

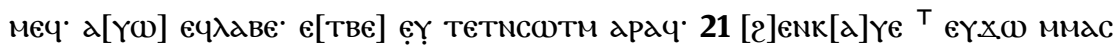

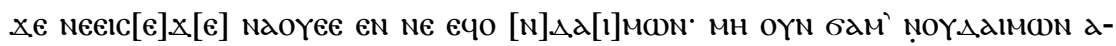

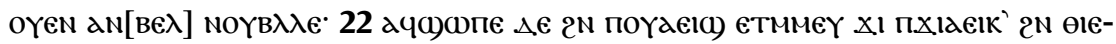

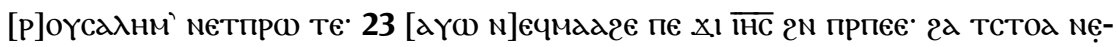

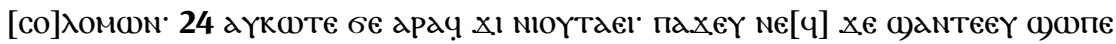

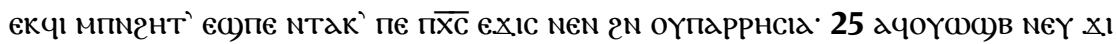

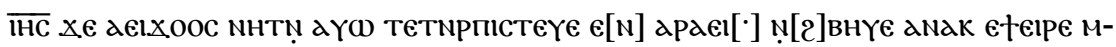

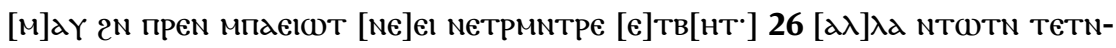

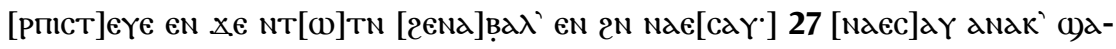

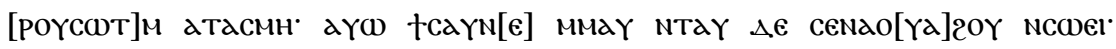

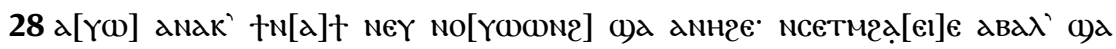

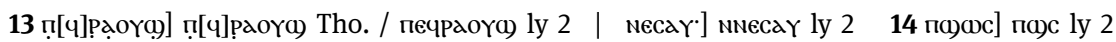

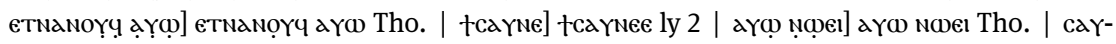

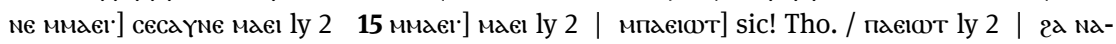

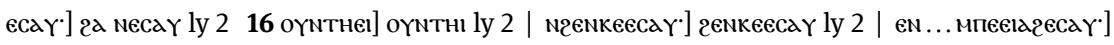

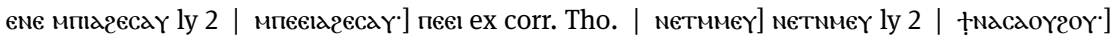
tnacd ' $\gamma^{\prime}$ '

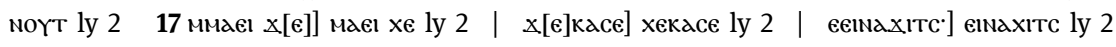

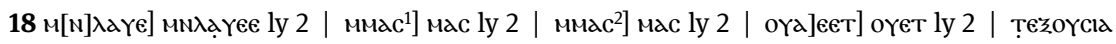

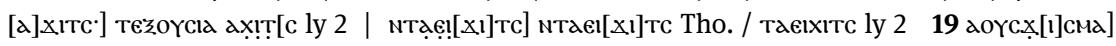

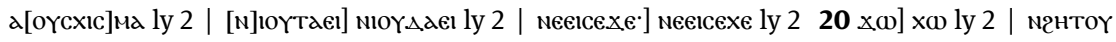

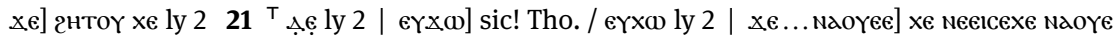

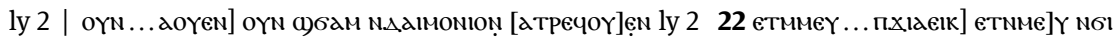

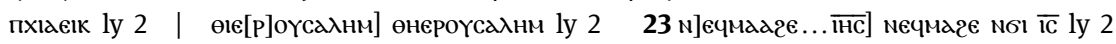

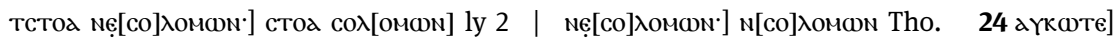

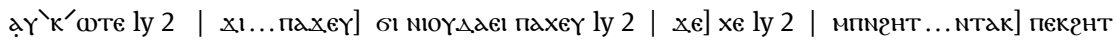

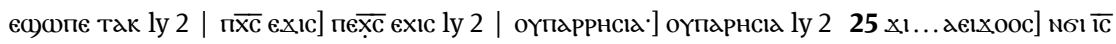

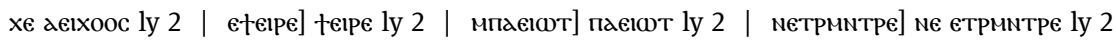

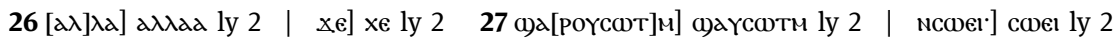

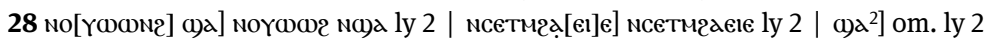




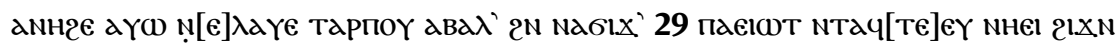

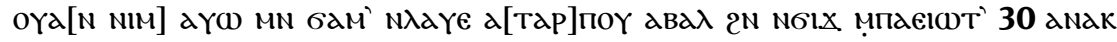

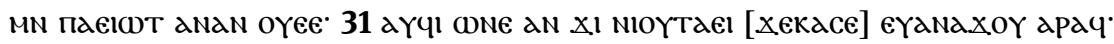

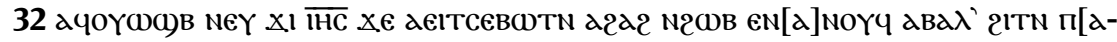

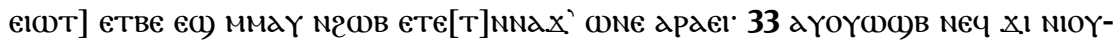

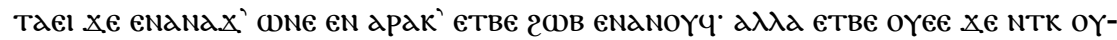

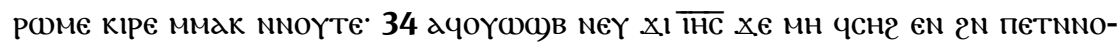

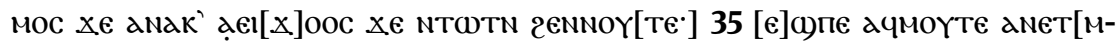

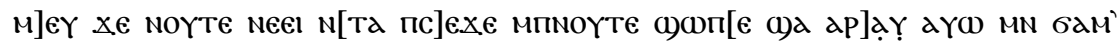

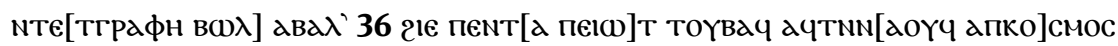

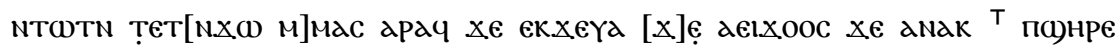

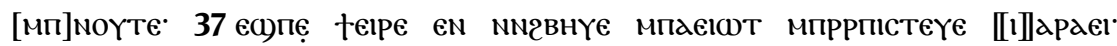

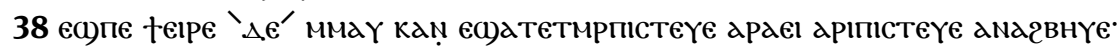

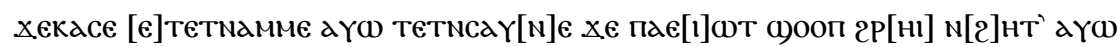

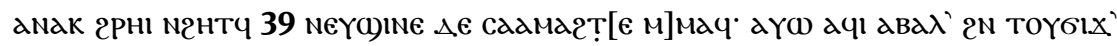

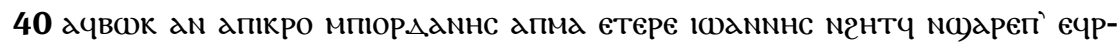

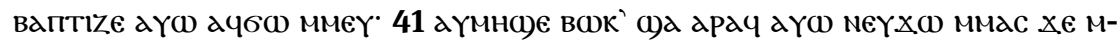

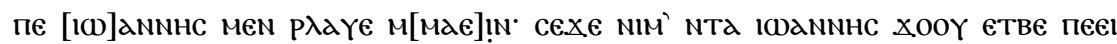
геNмне nе: 42 aүळ ага[2] рпістеүе арач.

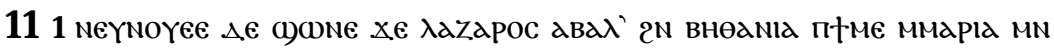

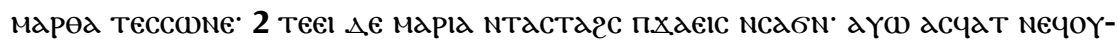

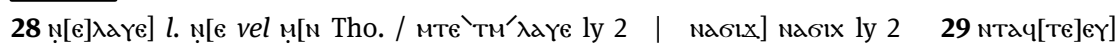

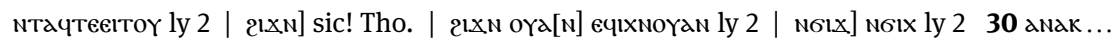

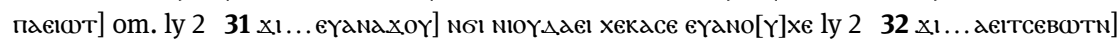

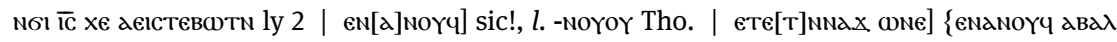

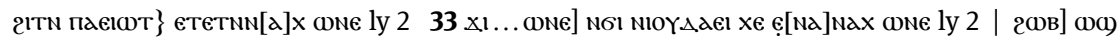

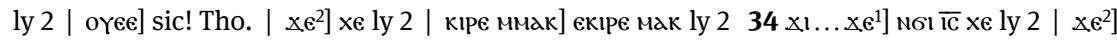

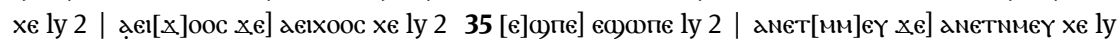

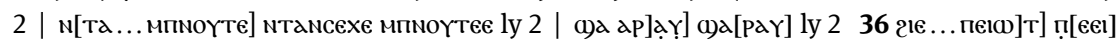

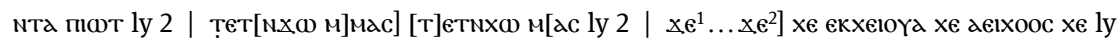

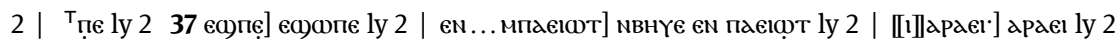

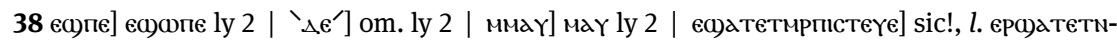

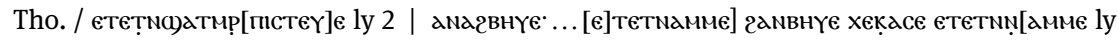

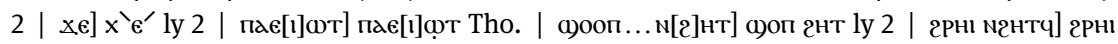

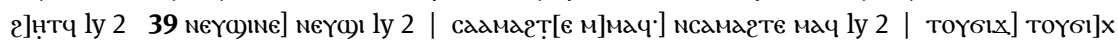

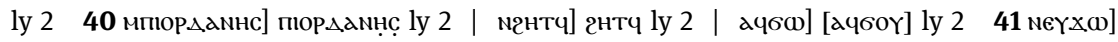

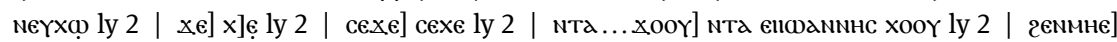

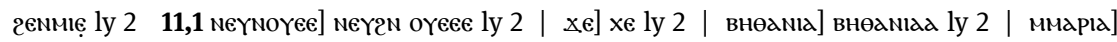

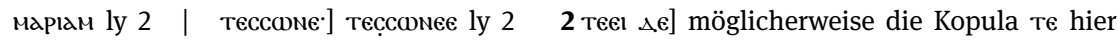

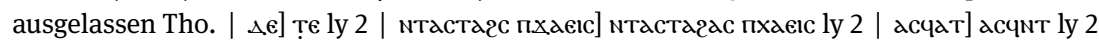




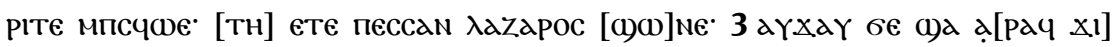

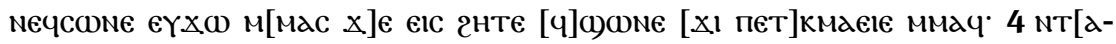

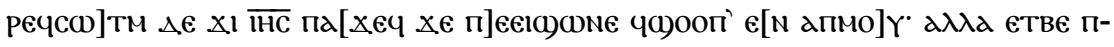

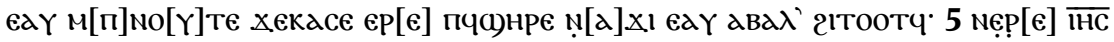

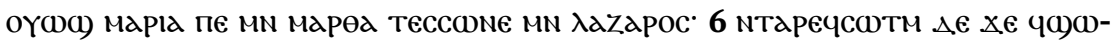

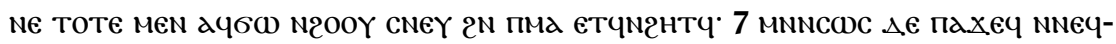

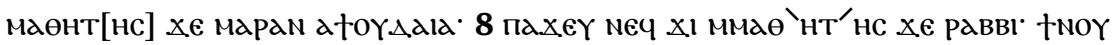

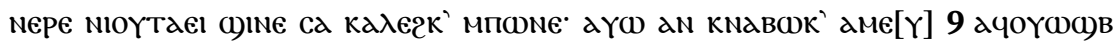

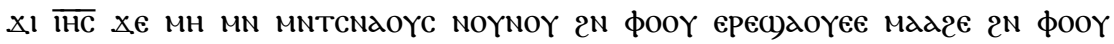

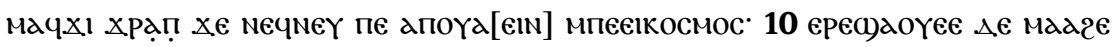

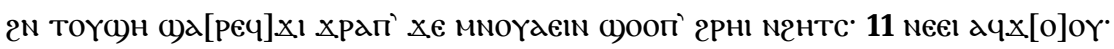

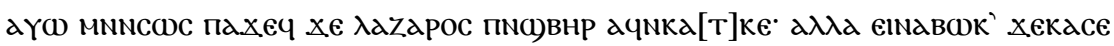

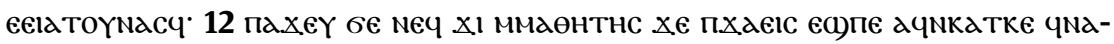

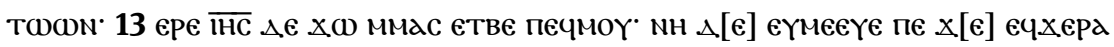

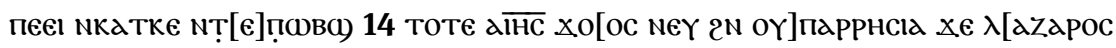

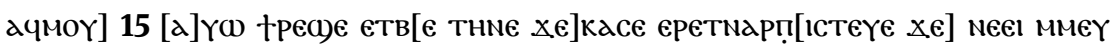

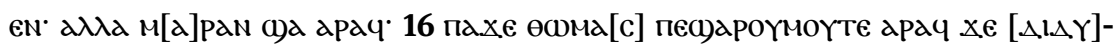

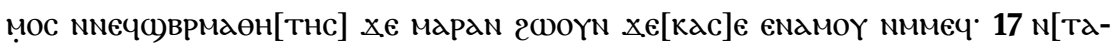
pe]

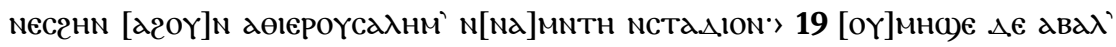

2 мпсчше ... пессан] мпесчоүе те[є]ı те песан ly 2 | [тн]] unsicher, Platz für 2 Buchstaben

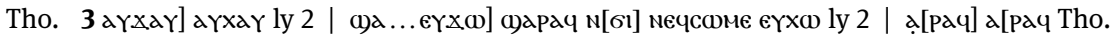

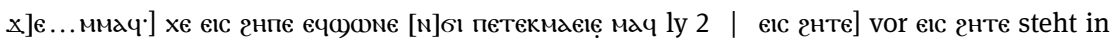

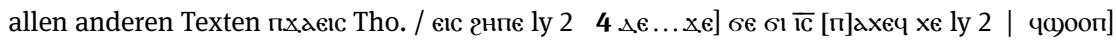

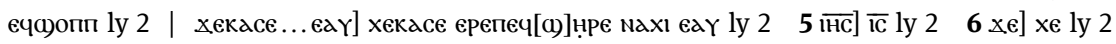

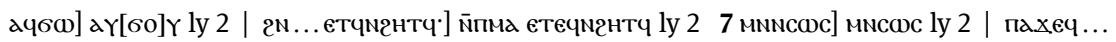

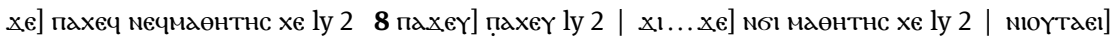

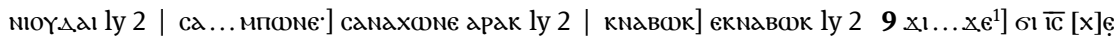

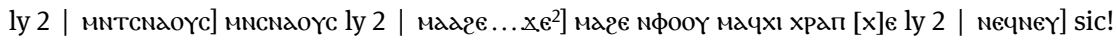

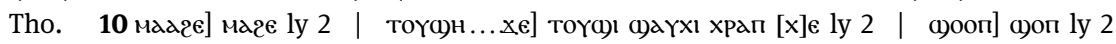

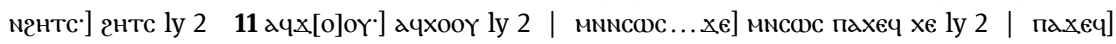

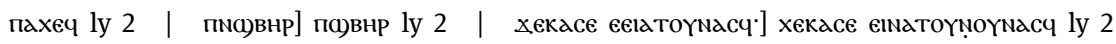

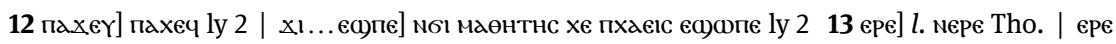
$\overline{\mathrm{IHC}}]$ ep€ $\overline{\mathrm{ic}}$ ly $2 \mid x \omega]$ xw ly $2 \mid \Delta[\epsilon]]$ s sollte wohl am Zeilenende hinzugefügt werden, um den Imperfekt меүмеєүе zu bilden Tho. | еүмеєүе...ечхерд] меүмеүе хе ечхе ly 2 | ечхерд] viell. noch 1 oder 2 Buchstaben danach am Zeilenende Tho. | пєеl] пєє legt nahe, dass єтвє vor мKגтKe ausgefallen ist (cf. bo. und gr.), aber viell. ist es (auch) korrupt für die sa. Lesung

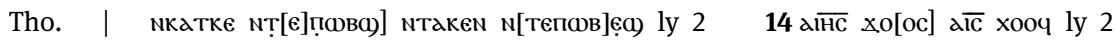

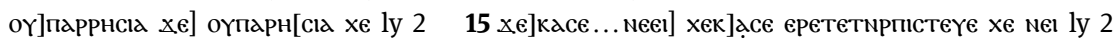

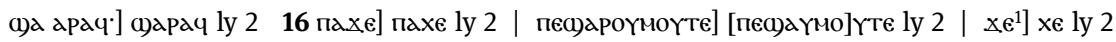
$\left.\left.x \epsilon^{2}\right] \mathrm{xe}\right]$ ly 2 | NАMав ly 2 


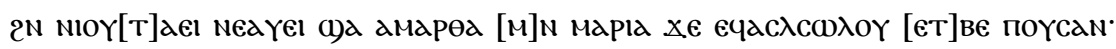

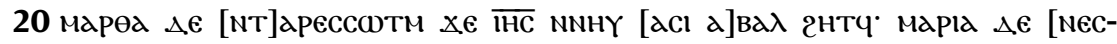

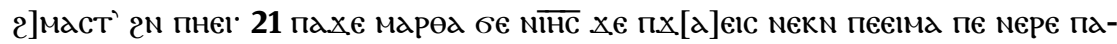

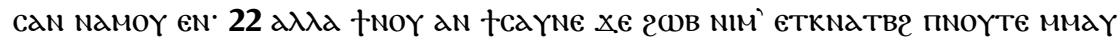

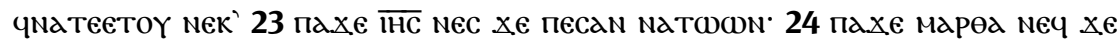

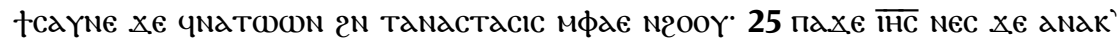

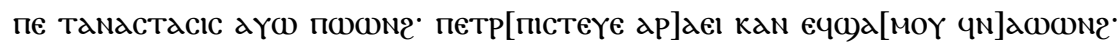

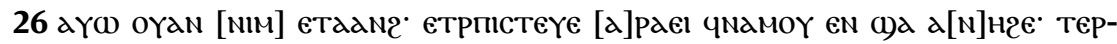

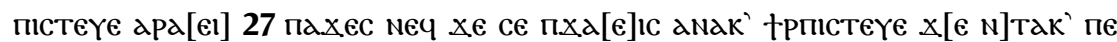

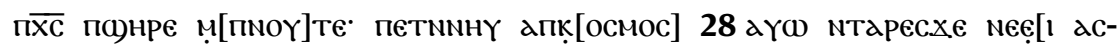

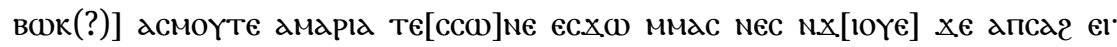

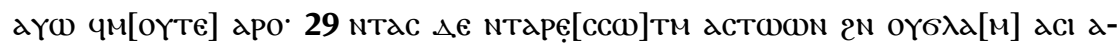

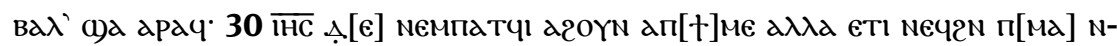

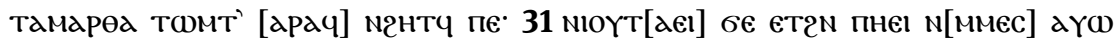

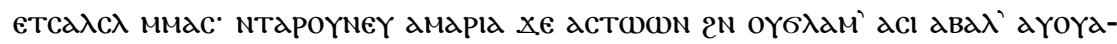

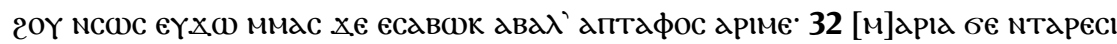

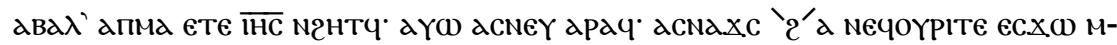

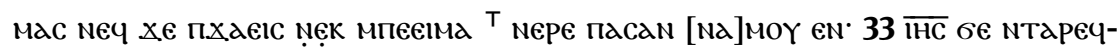

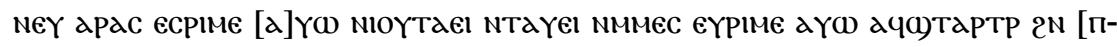

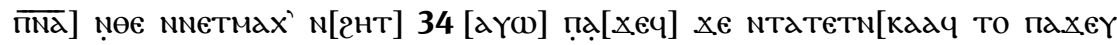

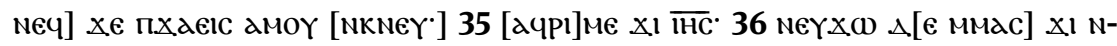

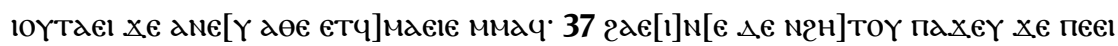

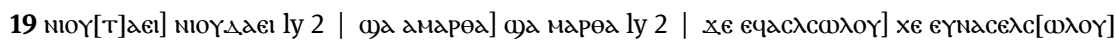
ly 220 хе... мннү] хе $\overline{\mathrm{ic}}$ мнү ly $2 \mid$ а]

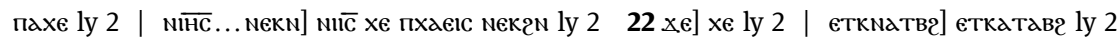

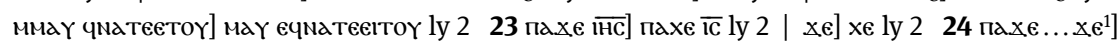

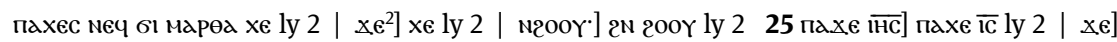

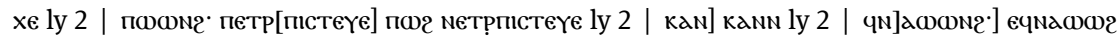

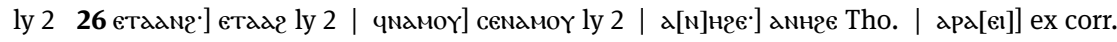

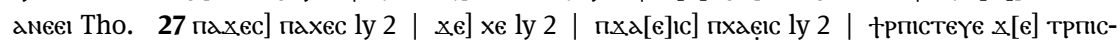

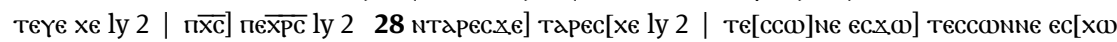

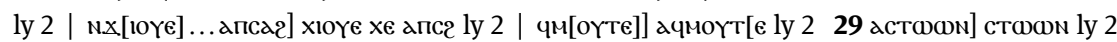

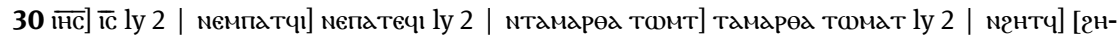

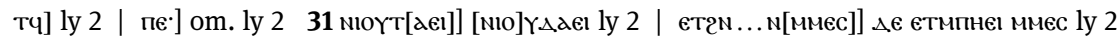

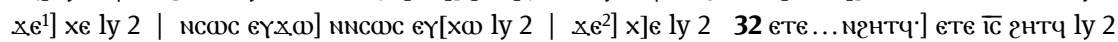

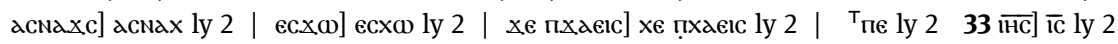

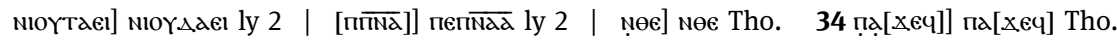

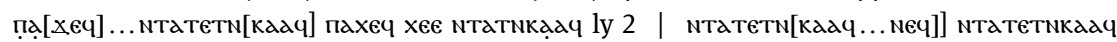
то пдхеч [nеq] Tho., aber nach nтатетN- lacuna | пахеү... пхдеı] пахеү хе пхдеıс ly 2

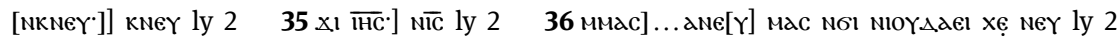

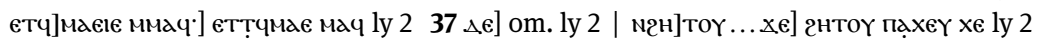




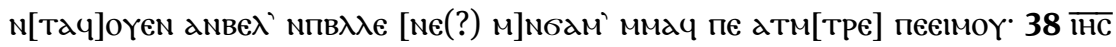

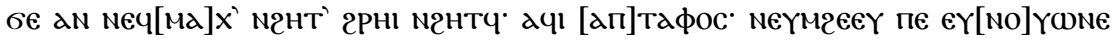

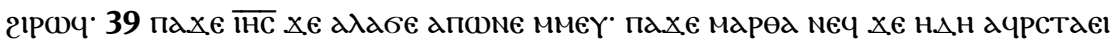

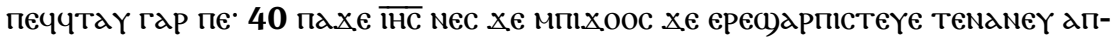

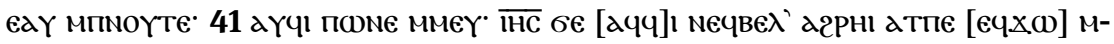

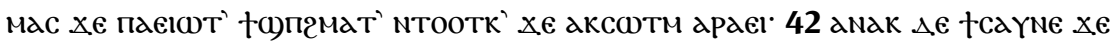

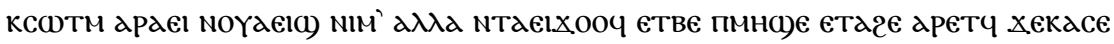

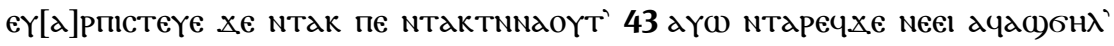

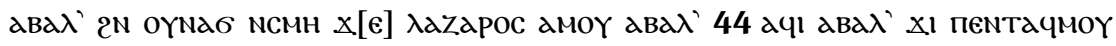

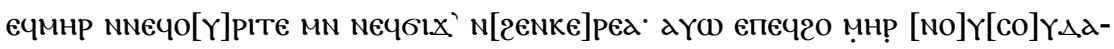

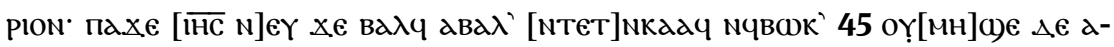

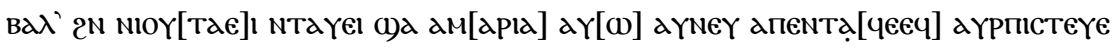

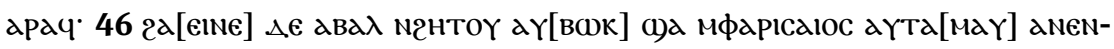

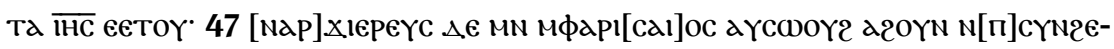

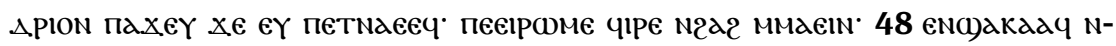

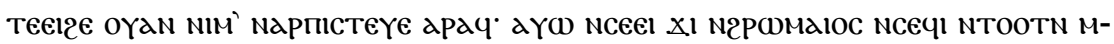

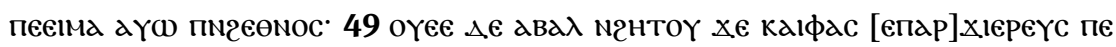

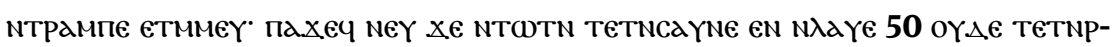

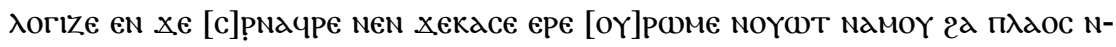

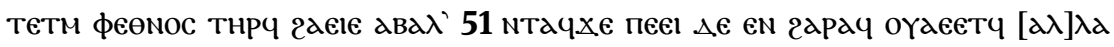
пархієрєүс пє мтрампє етммеү ечр[про]фнтєүє Хе мерє $\overline{\mathrm{iHC}}$ Nамо[Ү 2а]

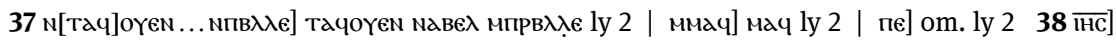

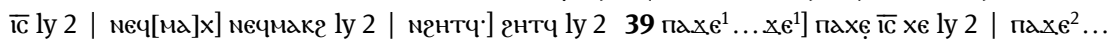

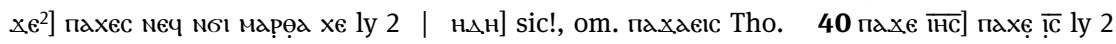
$\left.x \epsilon^{1} \ldots x \epsilon^{2}\right]$ xє мпххос $x \in$ ly 2 | мпхоос] danach Zeilenende und keine weitere Schriftspur

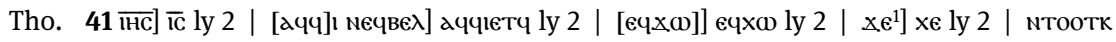
xe] тоотк xe ly 242 xe $e^{1}$ xe ly 2 | noүaeic)] noүac) ly 2 | nTaeixooy] sic! Tho. / Taeixooy ly

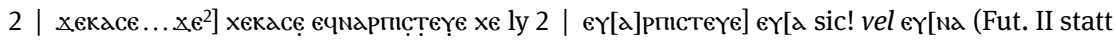

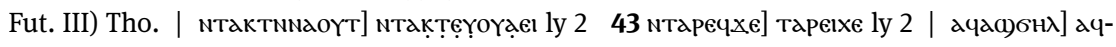

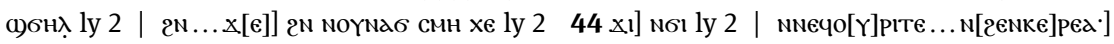

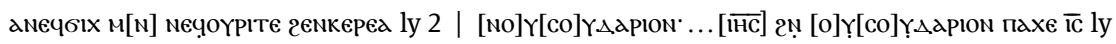

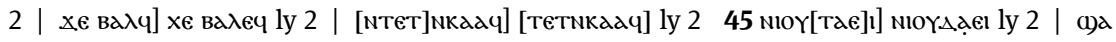

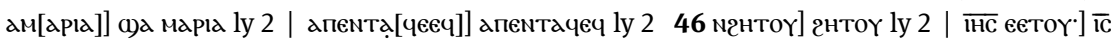

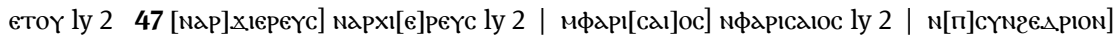

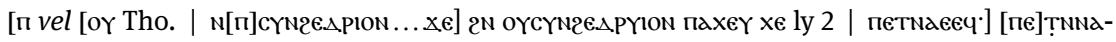

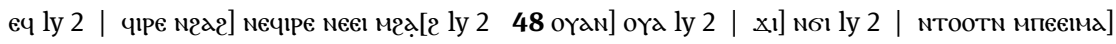

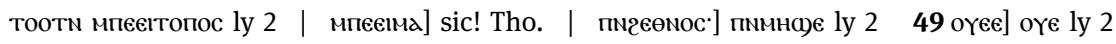

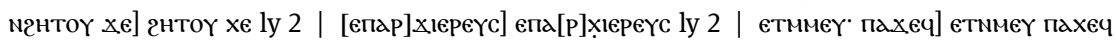

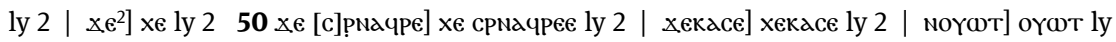

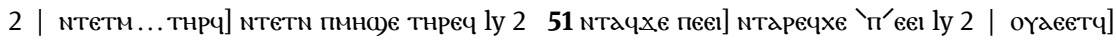

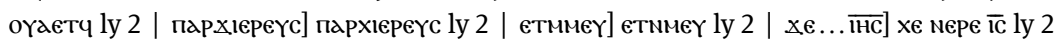




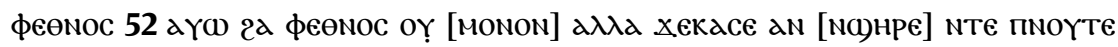

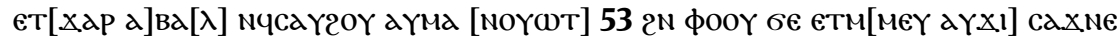

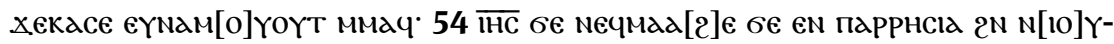

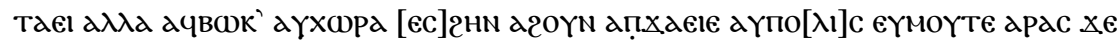

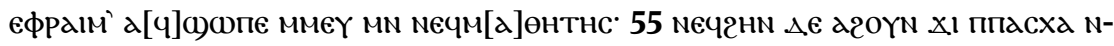

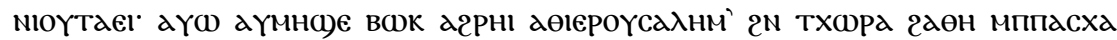

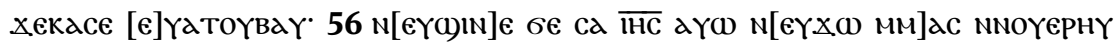

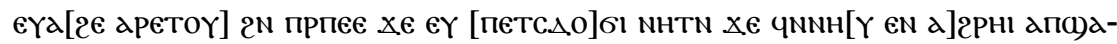

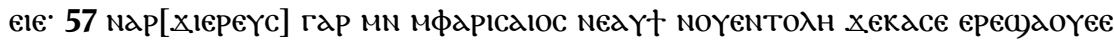
мме Хе ечто єчатамаY Хекасе еүNaGaпч.

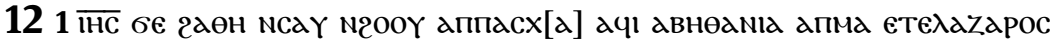

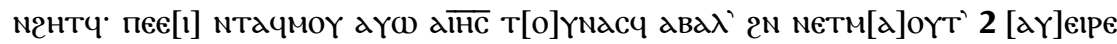

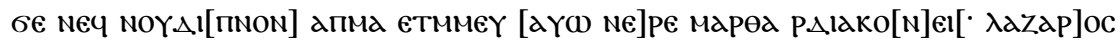

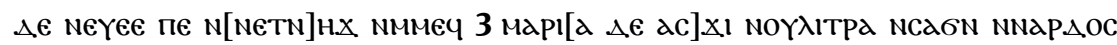

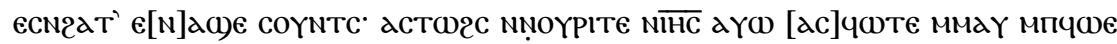

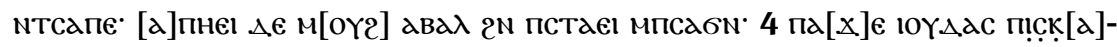

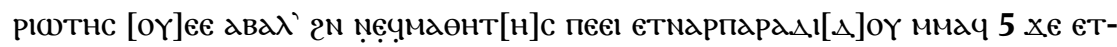

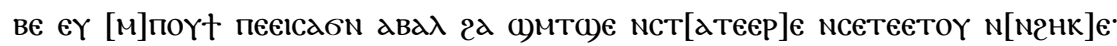

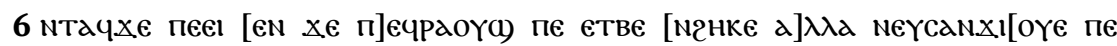

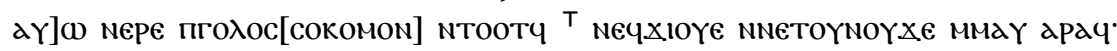

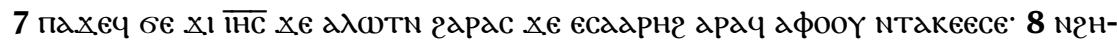

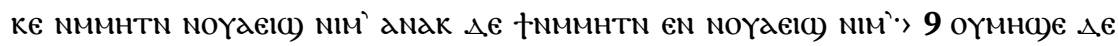

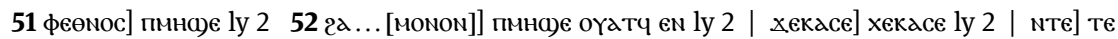

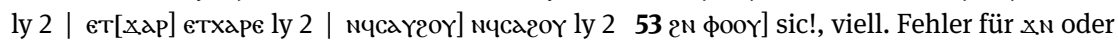

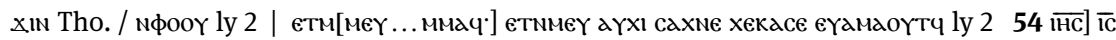

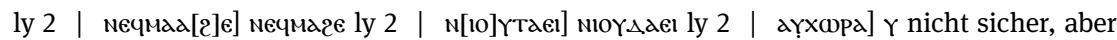
möglich, cf. bo. Tho. $\mid$ [єс]2нн] ec], da ist ein Rest des 2. Buchstabens, der aber nicht $\mathrm{T}$ sein

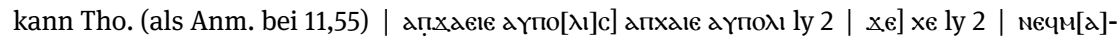

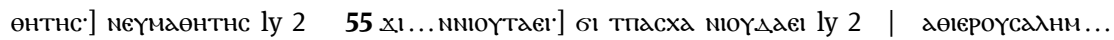
тхора] дөєероүсоднм тхора ly 2 | мппасха... [e]үатоүваү.] мтпасха хекасе еү ly 2 (sic!)

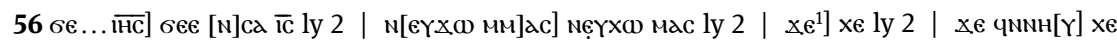

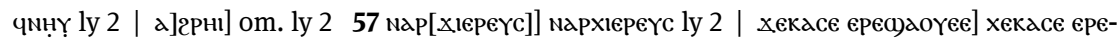

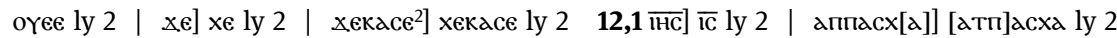

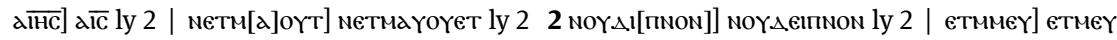

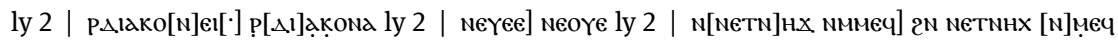

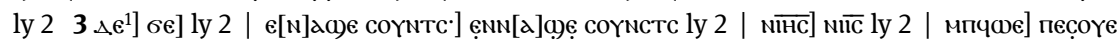

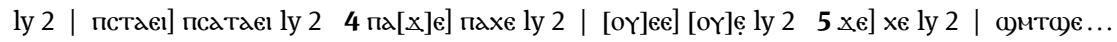

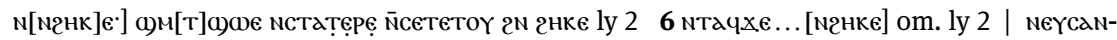

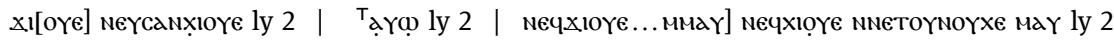

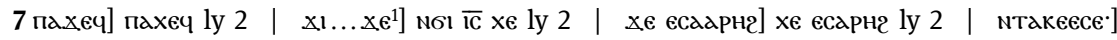

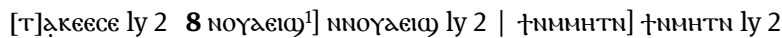




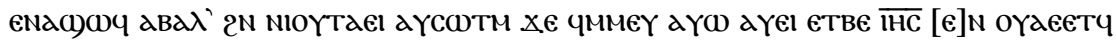

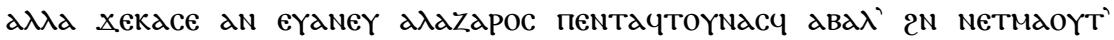

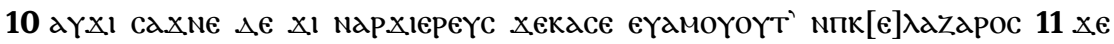

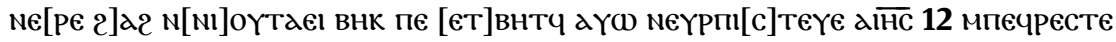

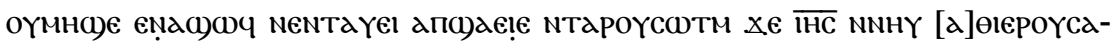

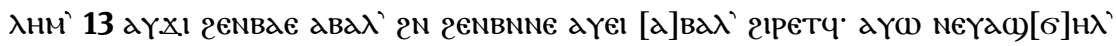

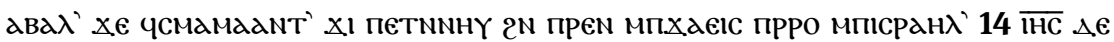

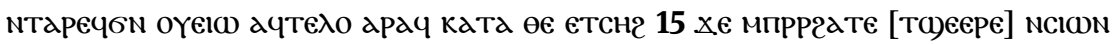

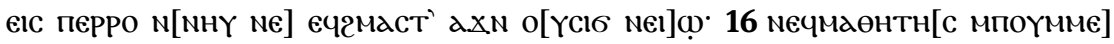

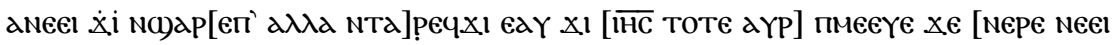

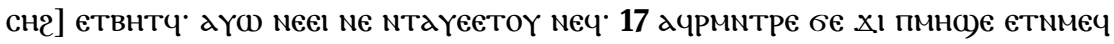

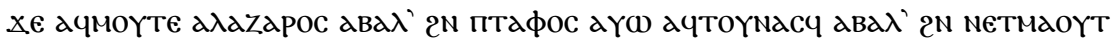

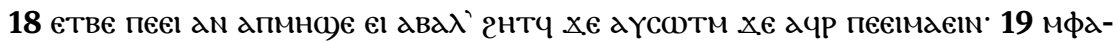

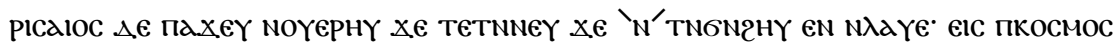

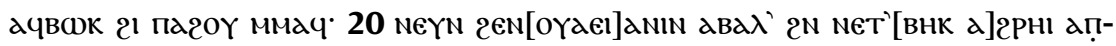

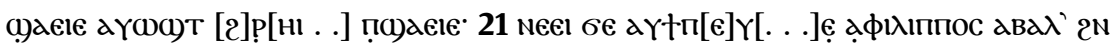

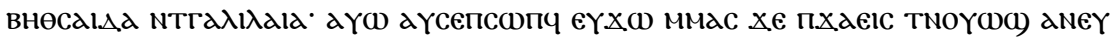

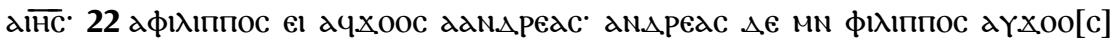

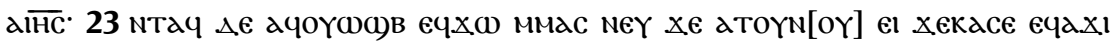

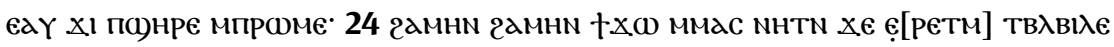

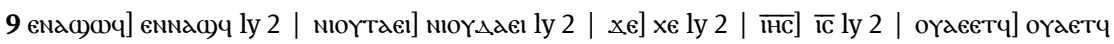
ly 2 | хекасе] хекасе ly 2 | an] om. ly 2 | метмаоүт] метмаүоүет ly $2 \quad 10$ aүхı са.хне] xl

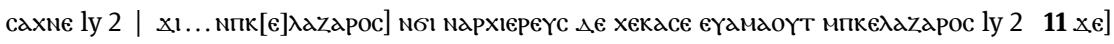

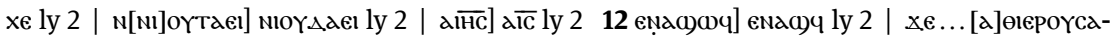

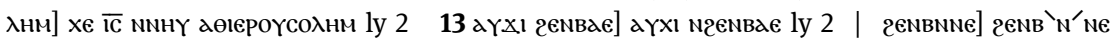

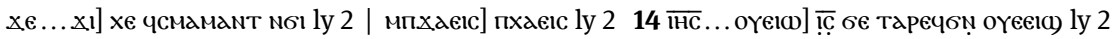

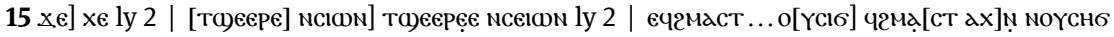
ly $2 \mid$ o[Үcı一] die Form cıб ist unischer, die sa. Form wäre снб Tho. 16 غ̇i] die Punkte mar-

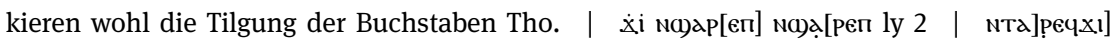

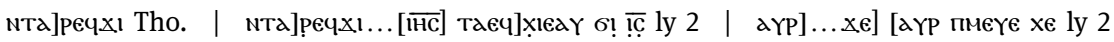

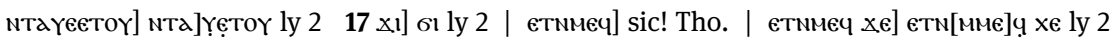

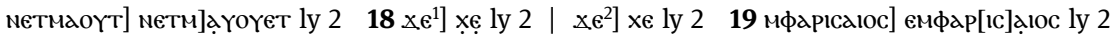

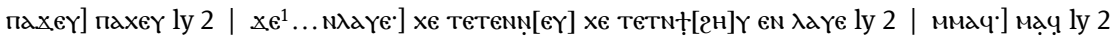

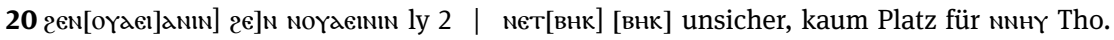

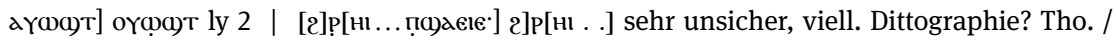

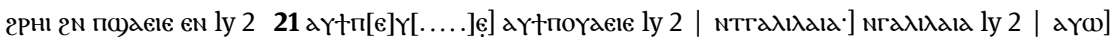

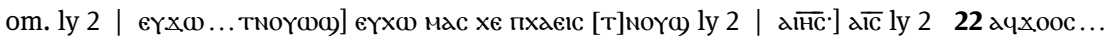

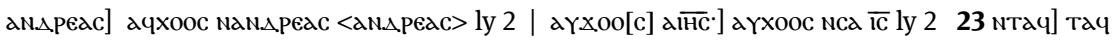
ly 2 | ачоүшов ечхю] [ачо]үळв ечхо ly 2 |

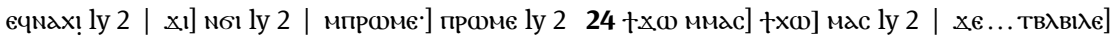

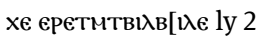




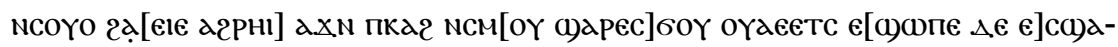

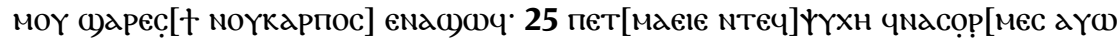

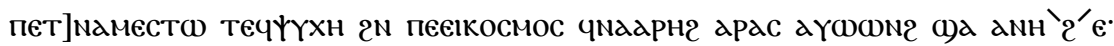

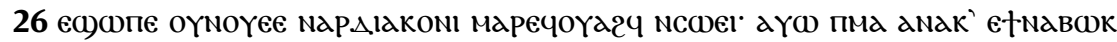

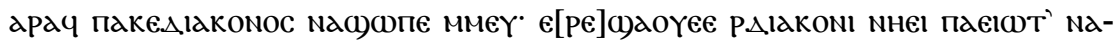

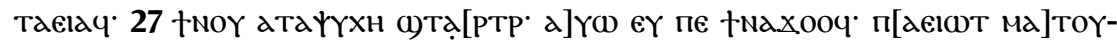

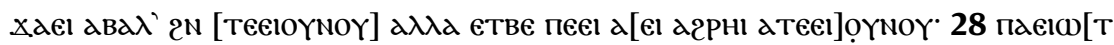

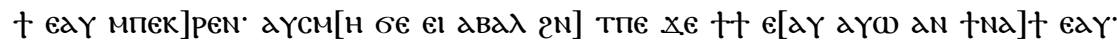

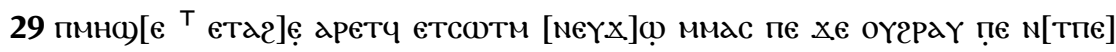

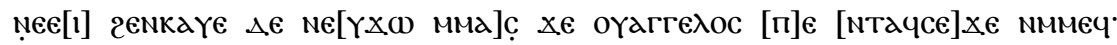

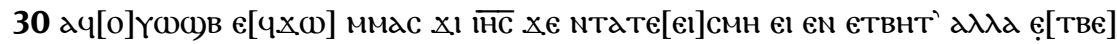

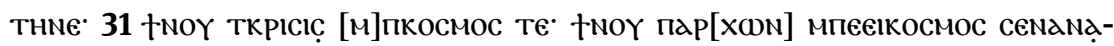

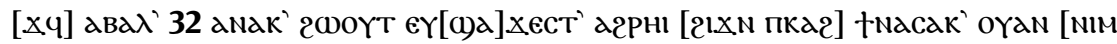

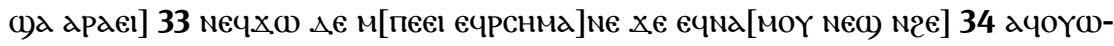

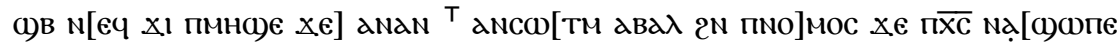

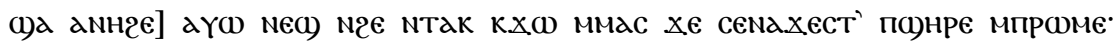

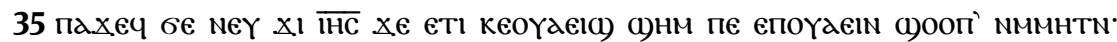

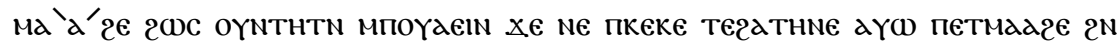

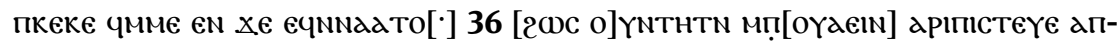

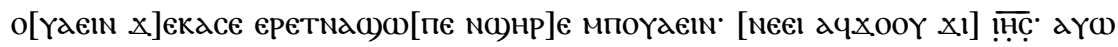

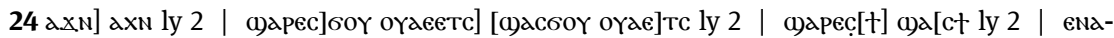

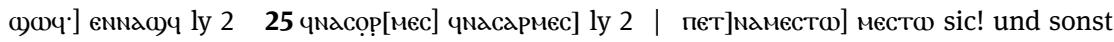

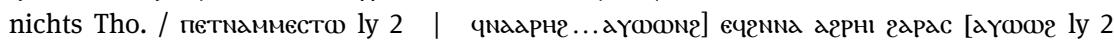

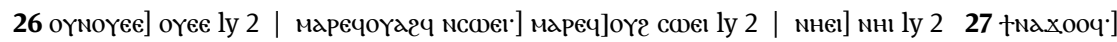

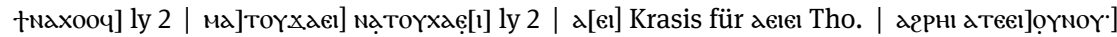

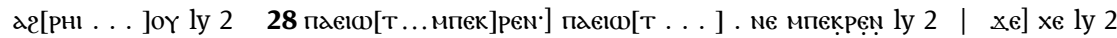
$29^{\top} \Delta \epsilon$ ly 2 | [неүх]

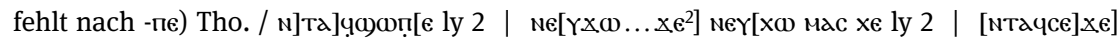

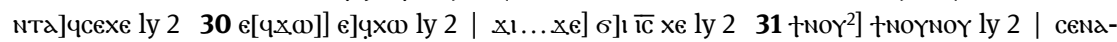

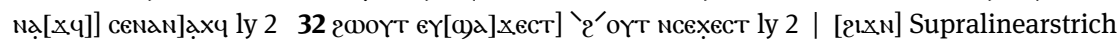
noch sichtbar mit Platz für 2 Buchstaben Tho. / axw ly 2 | +Nacak oүan] nTancak oүoүan ly

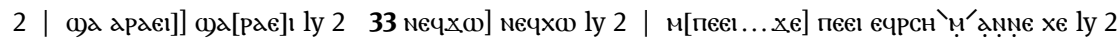

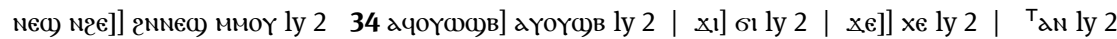

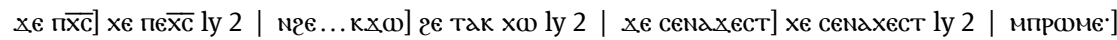
Versende ausgelassen wegen Homoioteleutons Tho. / проме ly 2 (Versende ebenfalls

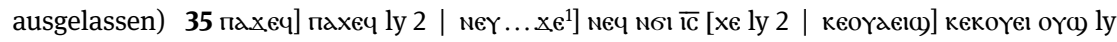

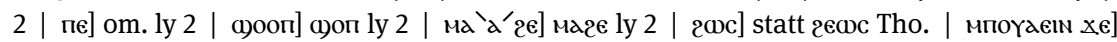

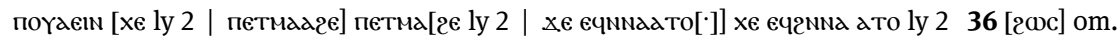

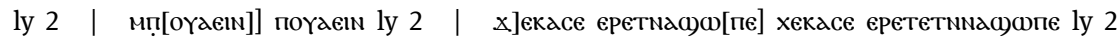

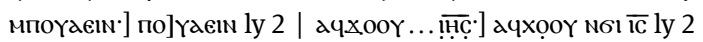




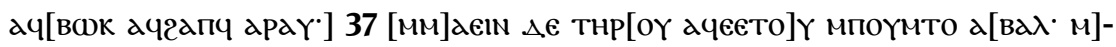

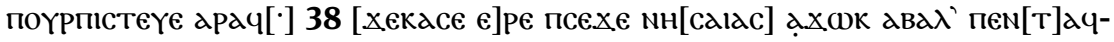

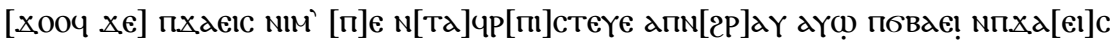
NTачб

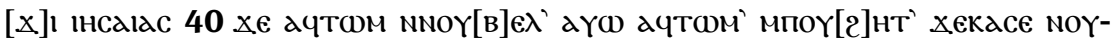

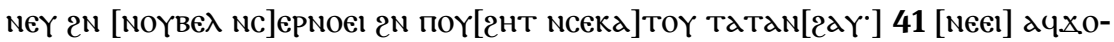

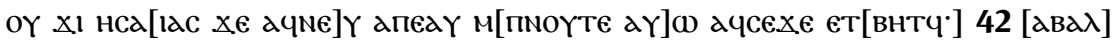

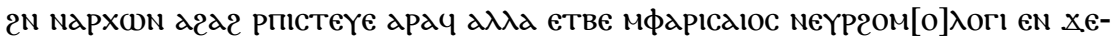

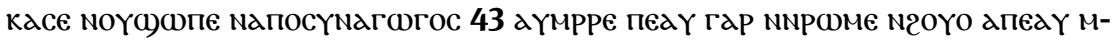

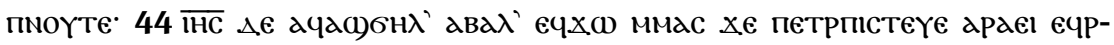

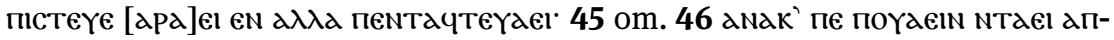

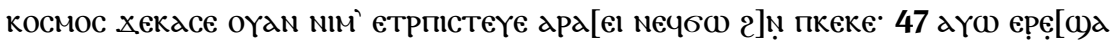
oүe]

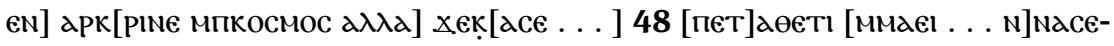

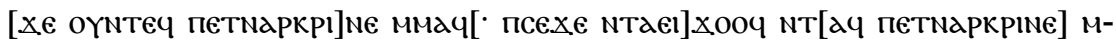

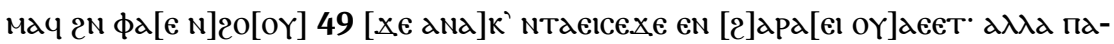

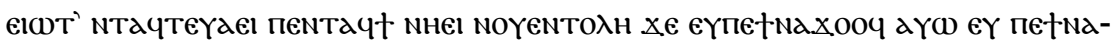

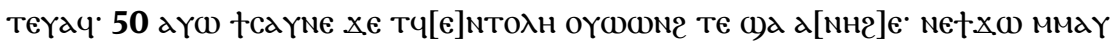

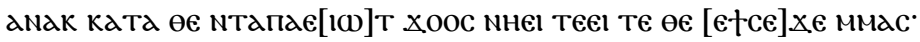

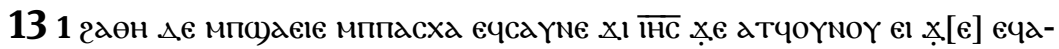

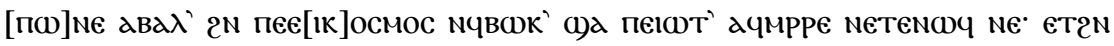

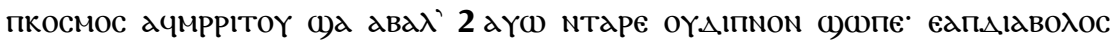

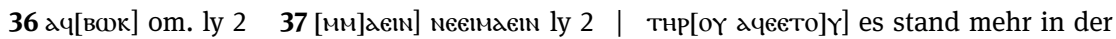
lacuna, viell. noch neeı vor ачеєтоҮ Tho. | ачеєто]Ү мпоүмто] м̣тач[єто]Ү мпоүмпто ly 2

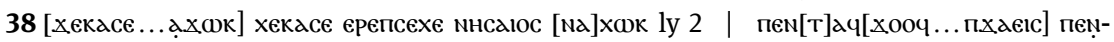

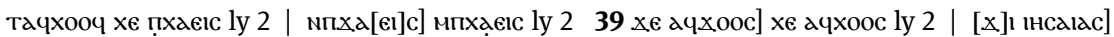

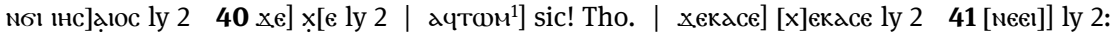

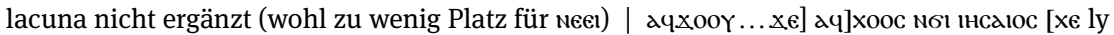

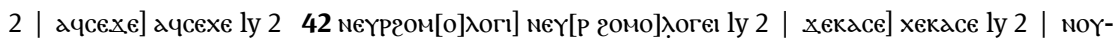

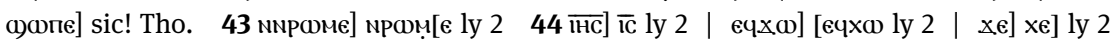

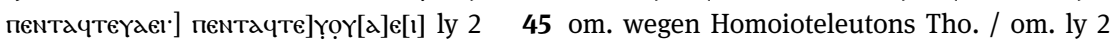

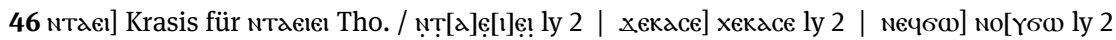
47 оүе]е] оүеєе ly 2 | а[масехе мчарнг]] anacẹ[хе мчтмарнг ly 2 | мчарнг]] vermutlich kein

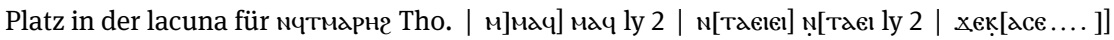

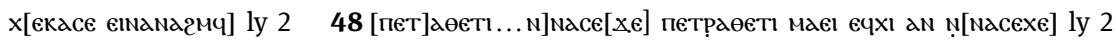

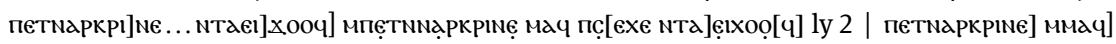

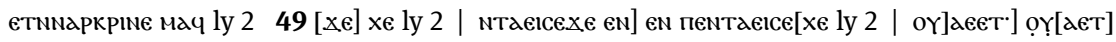

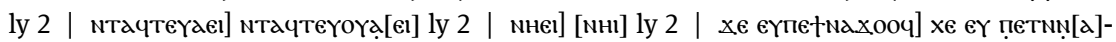

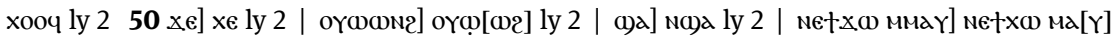

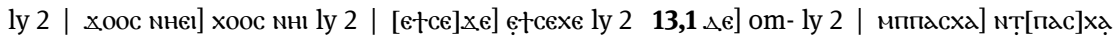

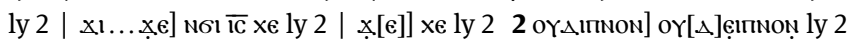




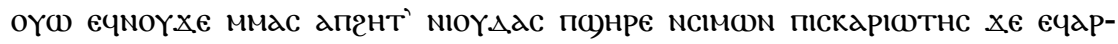

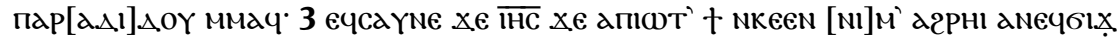

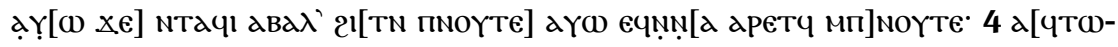

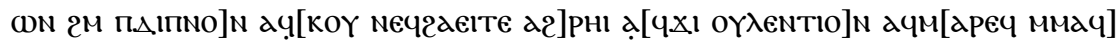

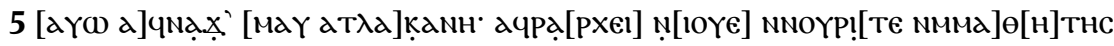

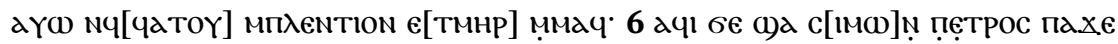

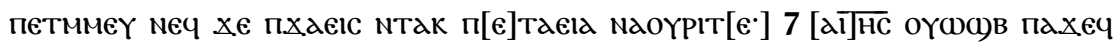

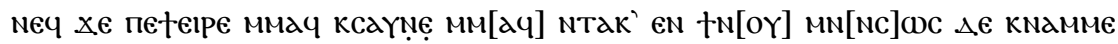

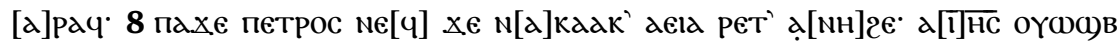

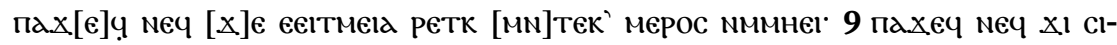

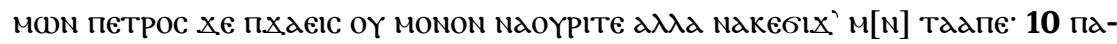
$x \in \overline{\mathrm{IHC}}$ Neq $x \in[\Pi \in \mathrm{N}] \mathrm{Ta}$.

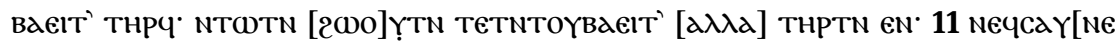

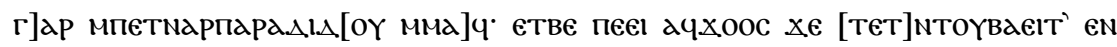

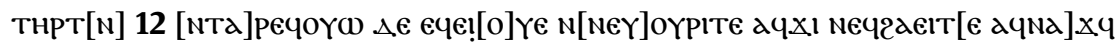

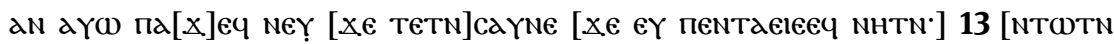

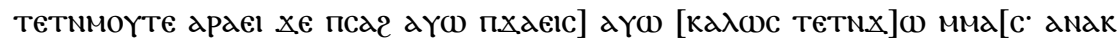
гар пє] 14 [є]

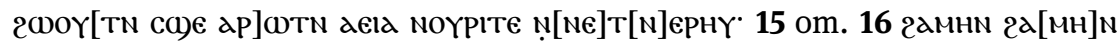

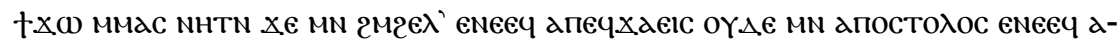

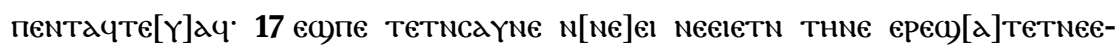

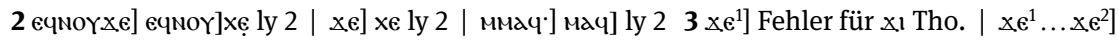

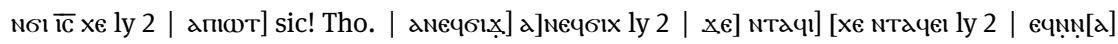

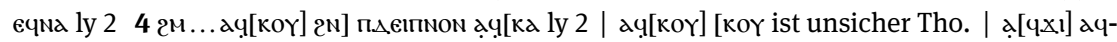
x! ly 2 | ммач]] мач] ly 25 a] lacuna kaum Platz für eюүe Tho. | ммма]е[н]тнс] ммечмдөнтبнс ly 2 | мч[чатоү]] мчатоү ly

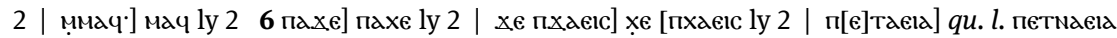

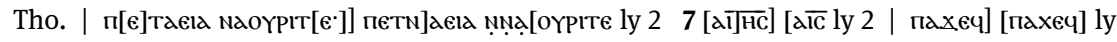

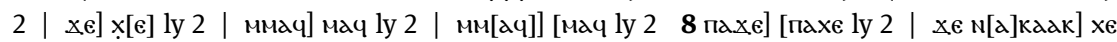

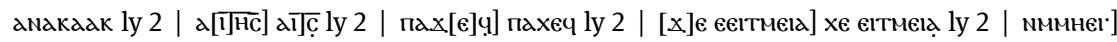

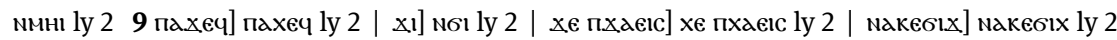

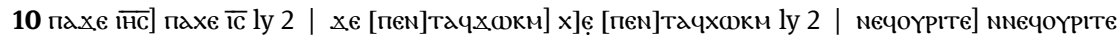

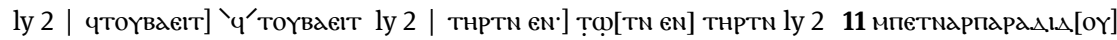

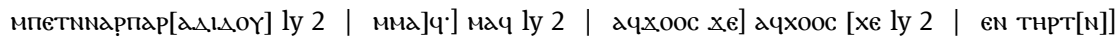

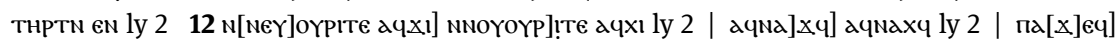

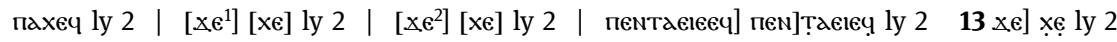

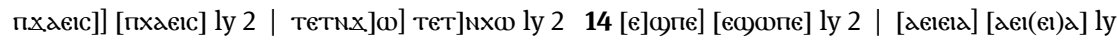

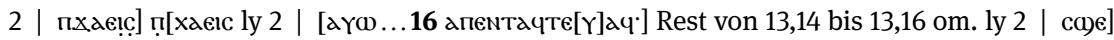

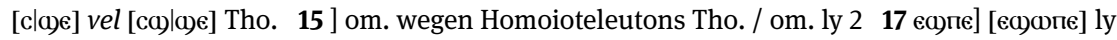

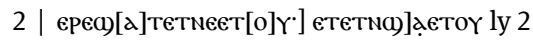




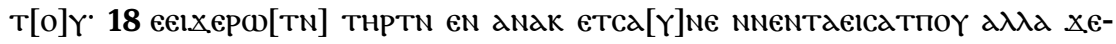

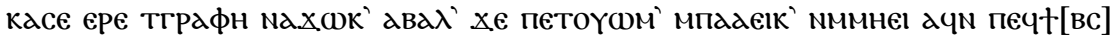

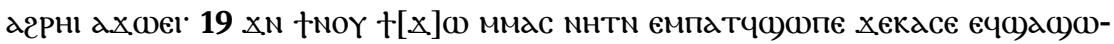

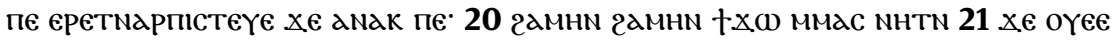

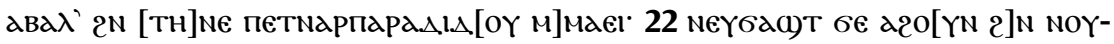

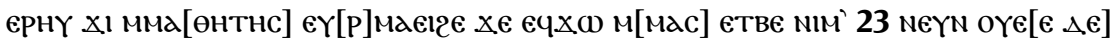

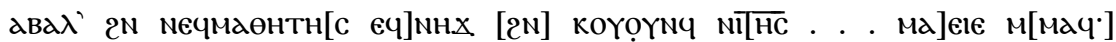

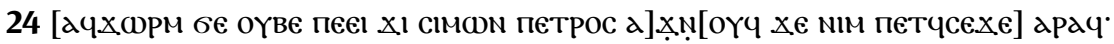

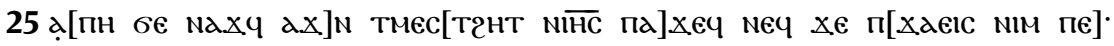

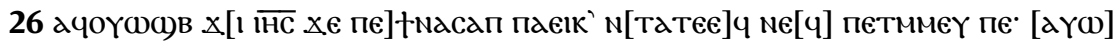

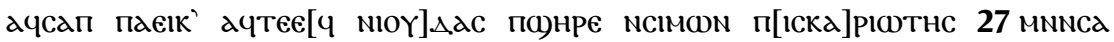

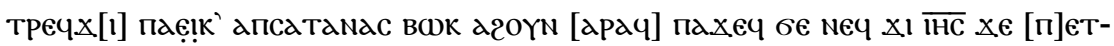

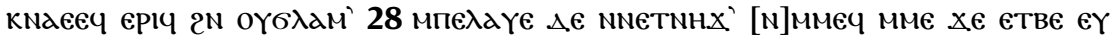

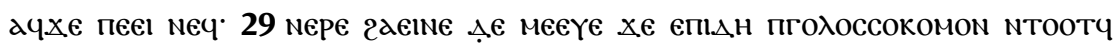

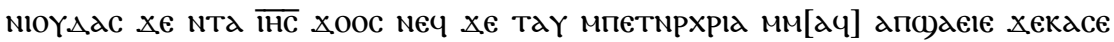

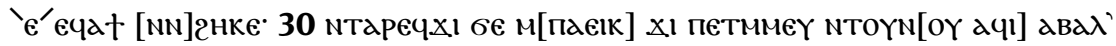

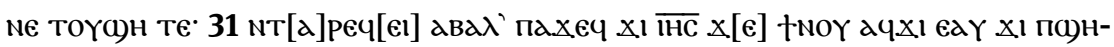

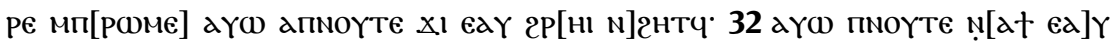

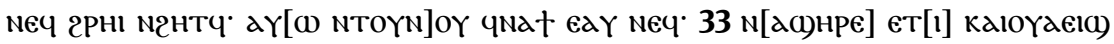

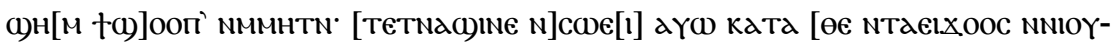

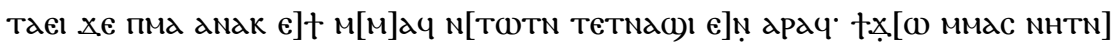

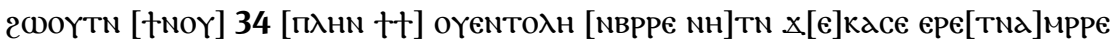

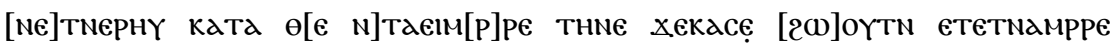

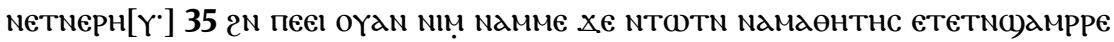

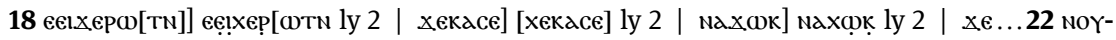
єрнү] Rest von 13,18 bis Beginn 13,22 om. ly 220 ...21 м] Mael] 13,20 großteils und 13,21 teils

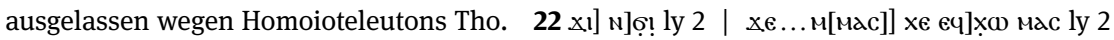

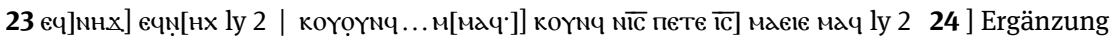

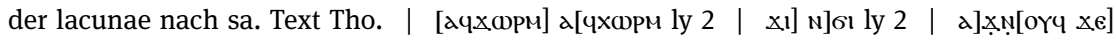

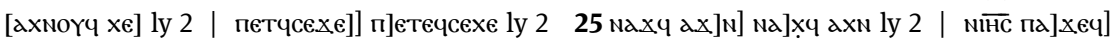

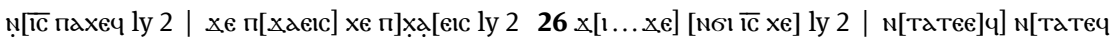
ly 2 | [aүo]] Ergänzung unsicher Tho. | дчcan] dy ist sicher, daher kann die Lesung nicht nтареч sein Tho. | ачтее[ч] [ачтеч] ly 2 | понре...27 апсатанас] Rest von 13,26 bis Beginn

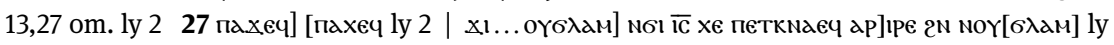

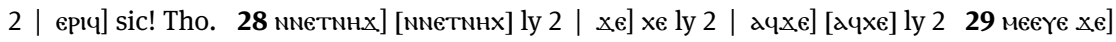

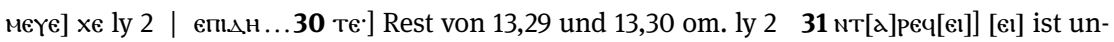

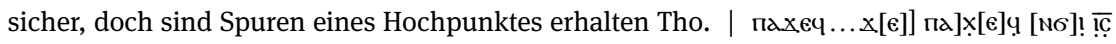

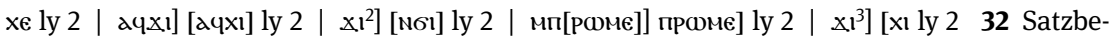
ginn ist ausgelassen wegen Homoioteleutons Tho. | 2PHI] om. ly 233 kaloүaeic)] kal ist ke

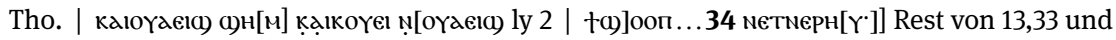

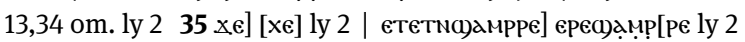




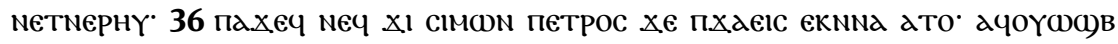

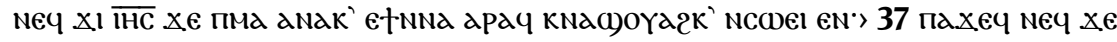

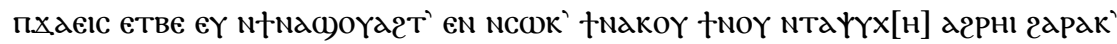

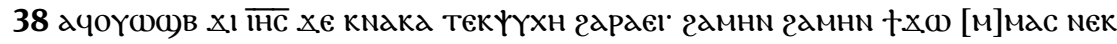

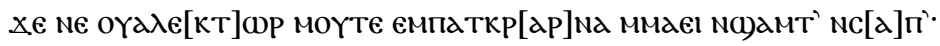

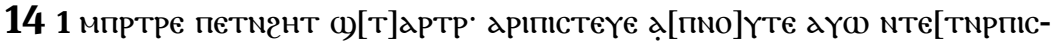

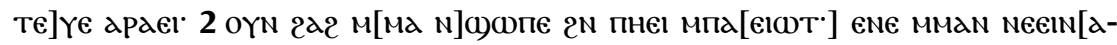

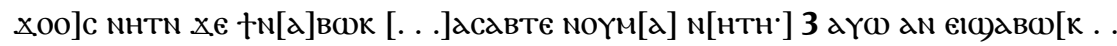

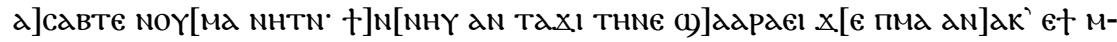
[Mач ететNa()

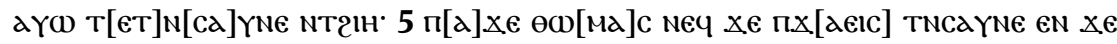

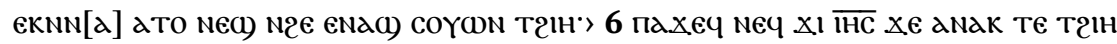

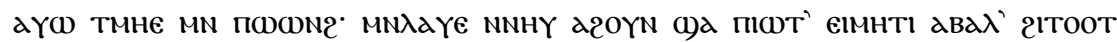

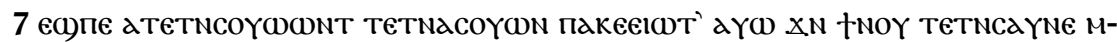

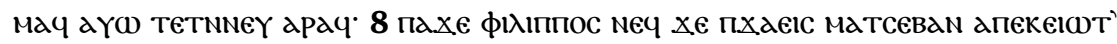

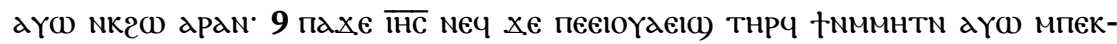

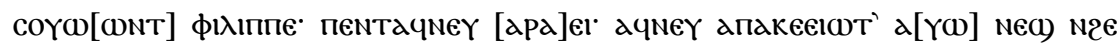

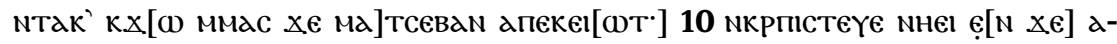

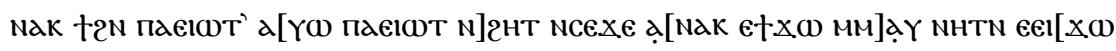

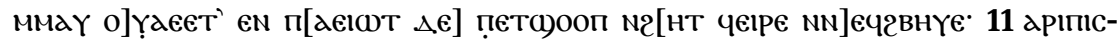

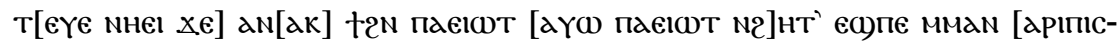

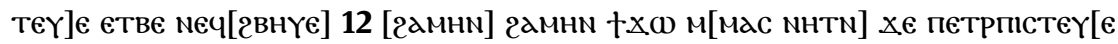

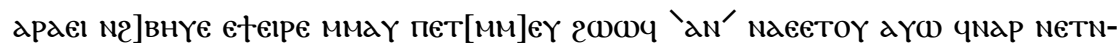

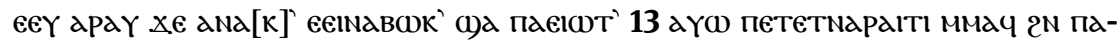

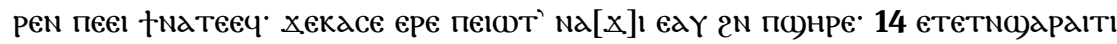

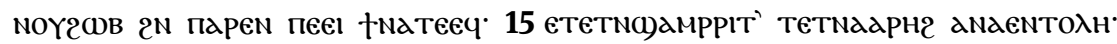

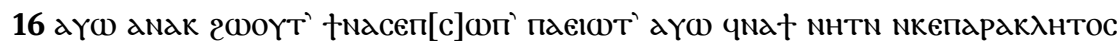

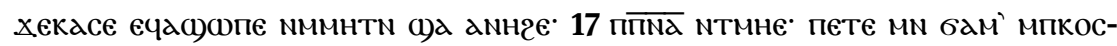

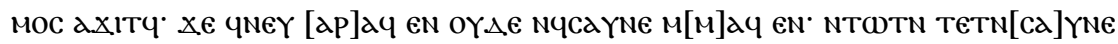

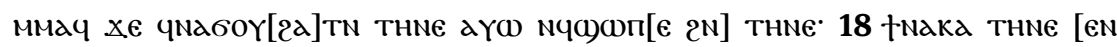

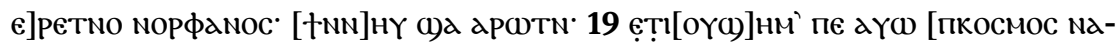

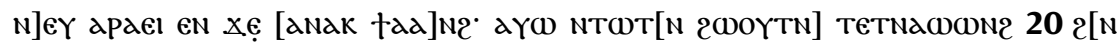

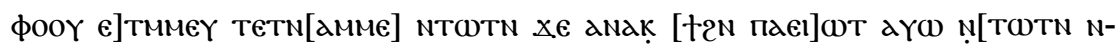

36 Satzende ist ausgelassen wegen Homoioteleutons Tho. | пахеч] [пахеч ly $\left.2 \mid x_{1}^{1}\right]$ NO1 ly

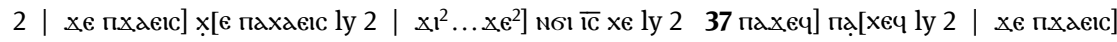

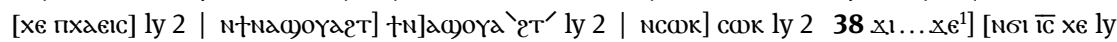

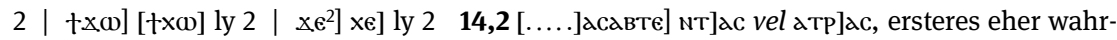
scheinlich Tho. $3 \mathrm{dN}^{2}$ ] unsicher Tho. 6 гттоот] ex corr. әттооту Tho. 19 [пкосмос] für бe kaum Platz vor космос Tho. 


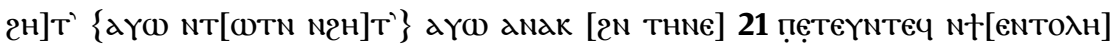

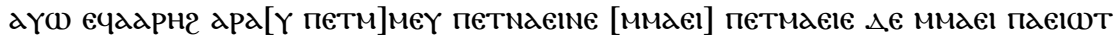

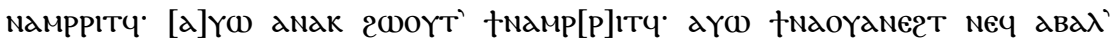

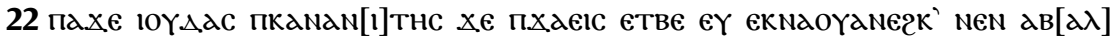

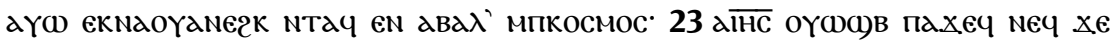

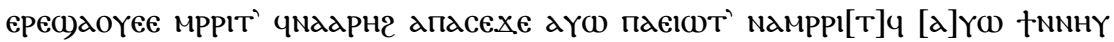

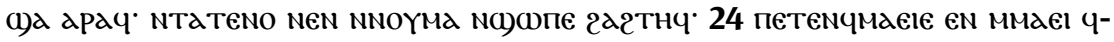

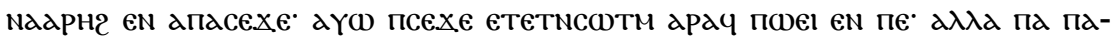

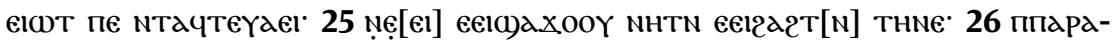

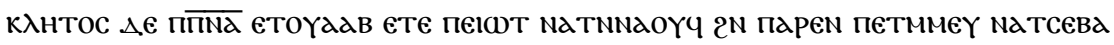

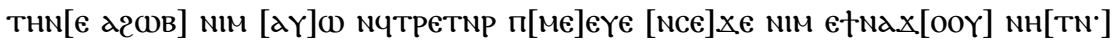

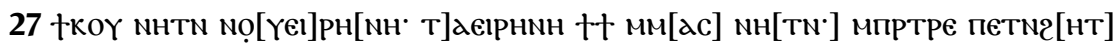

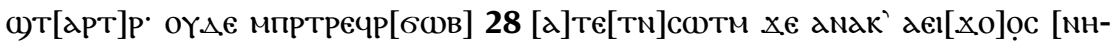

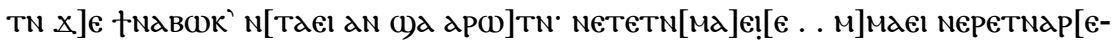

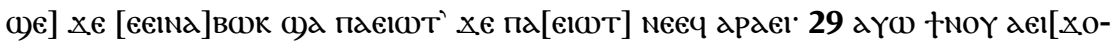

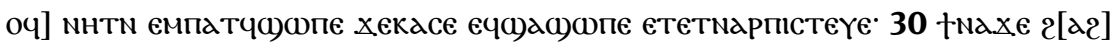

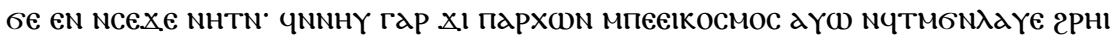

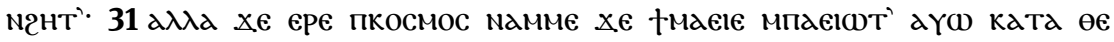

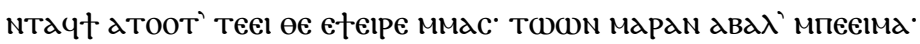

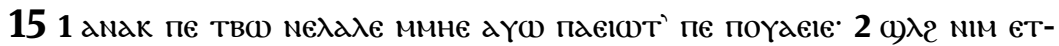

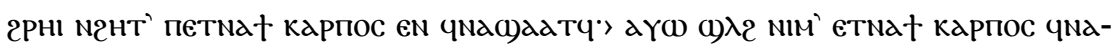

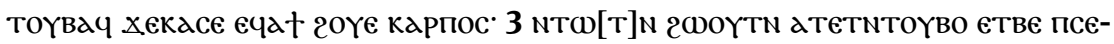

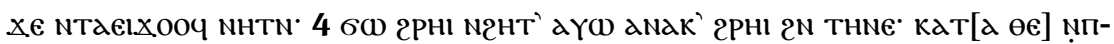

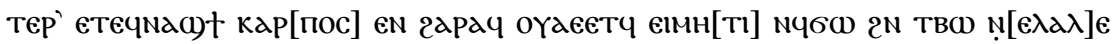

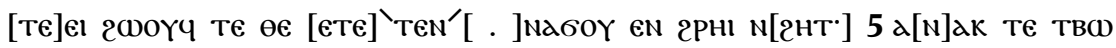

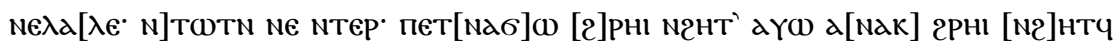
пеє [чNat oү]ка[рп]ос еNa)

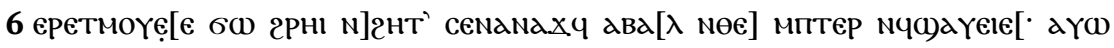

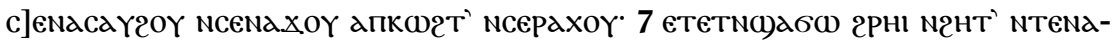

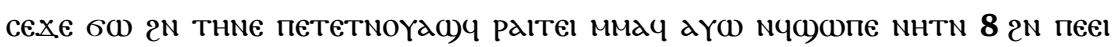

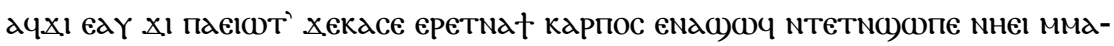

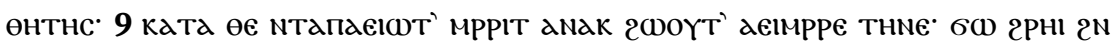

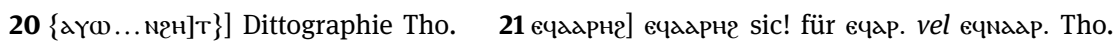

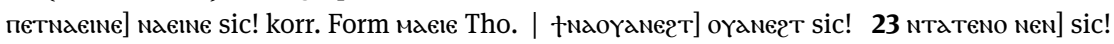
Tho. | ммоүма] sic! Tho. 24 па пдеіют] sic! Tho. $27 \mathrm{NH}[\mathrm{TN} \cdot]$ danach Satzteil ausgelassen

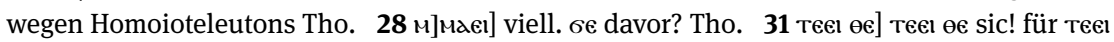
тє өє Tho. 15,3 nтגєıхооч] der Schreiber setzte danach fälschlicherweise einen Punkt am

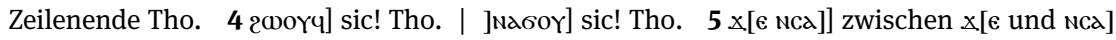
wohl Platz für 2 oder mehr Buchstaben in der lacuna Tho. 


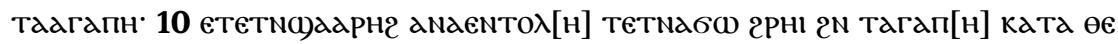

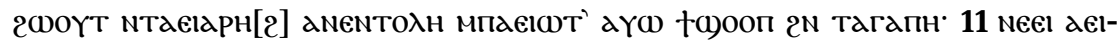

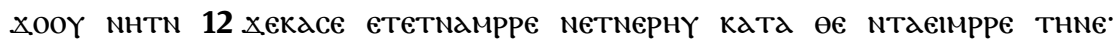

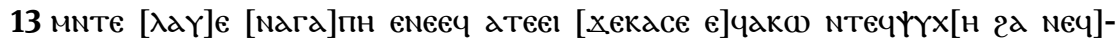

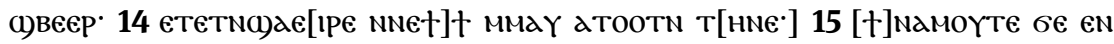

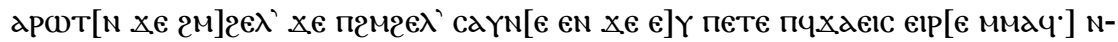

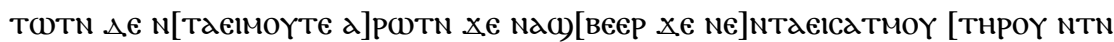

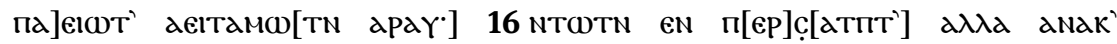

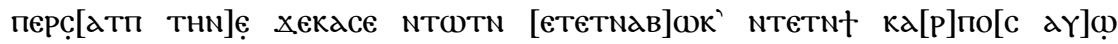

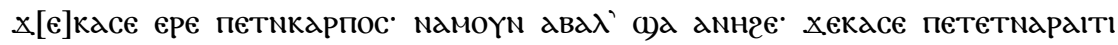

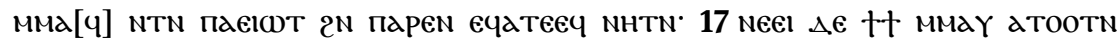

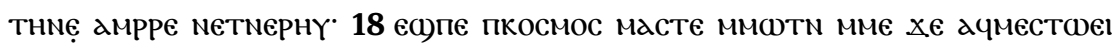

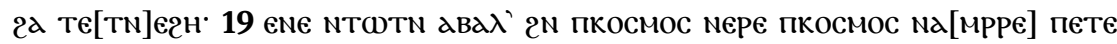

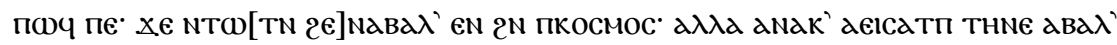

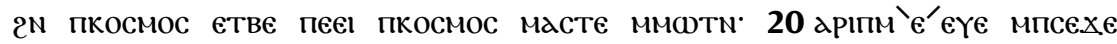

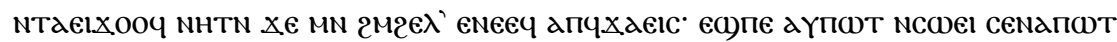

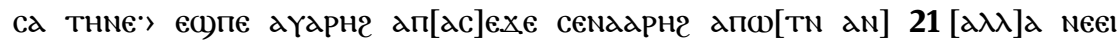

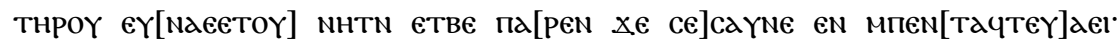

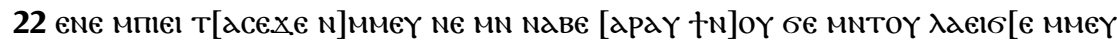

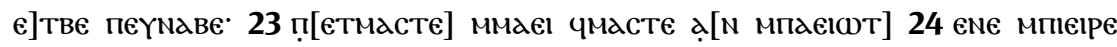

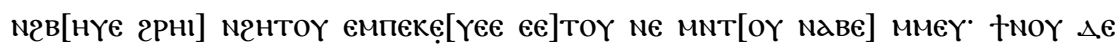

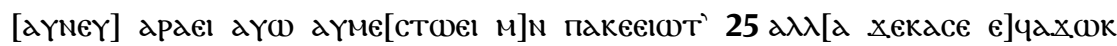

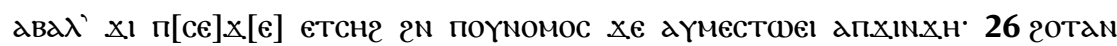

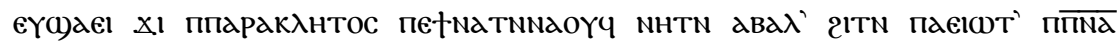

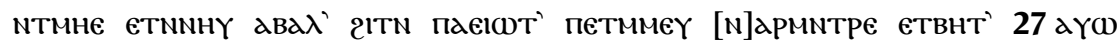

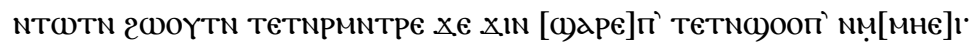

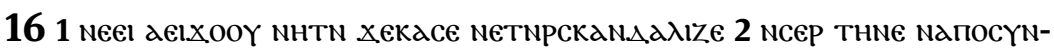

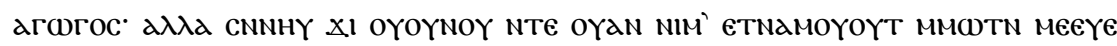

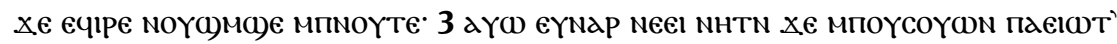

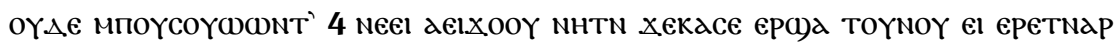

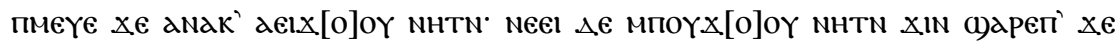

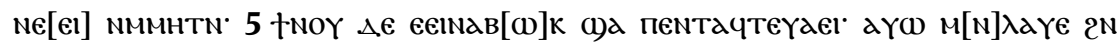

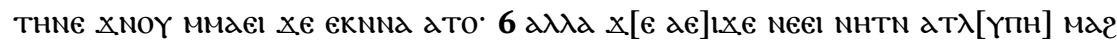

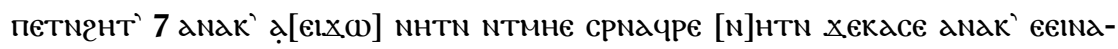

11 мнтм] danach Teile von 15,11 und 15,12 ausgelassen wegen Homoioteleutons Tho. 13 eneеч] sic! Tho. 14 ...ететм()גe[ipe] erster Satzteil von 15,14 ausgelassen wegen Homoioteleutons, Tho. 16 [ететлав] in der lacuna Tho. 16,4 мпоүх [o]or] sic! Tho. 


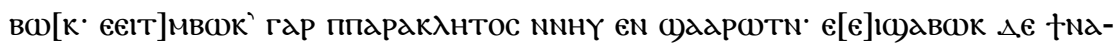

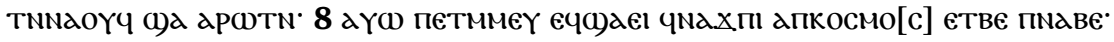

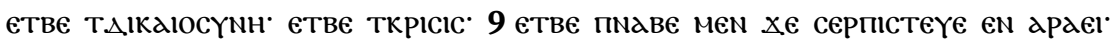

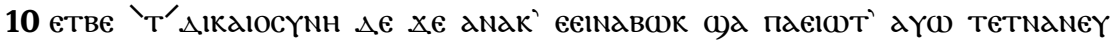

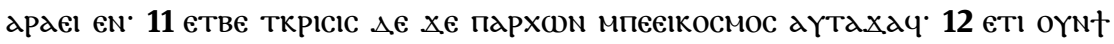

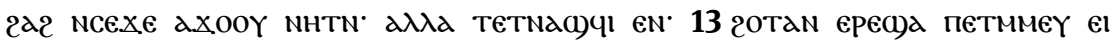

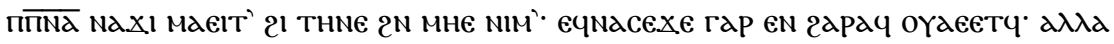

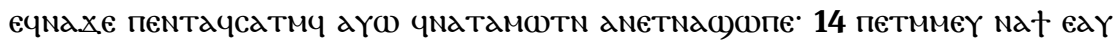

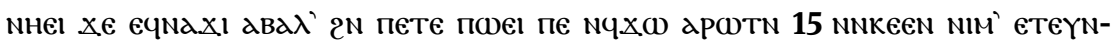

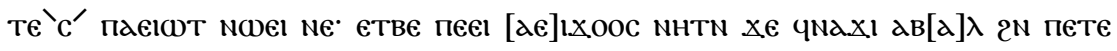

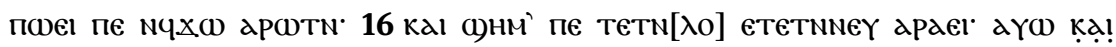

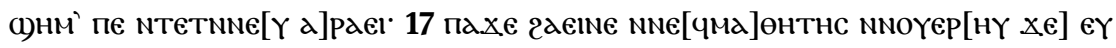

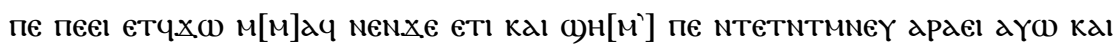

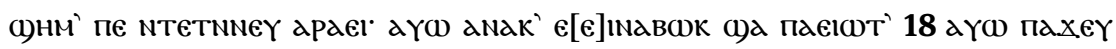

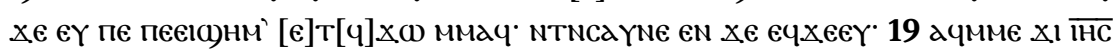

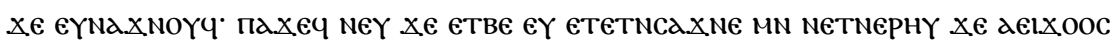

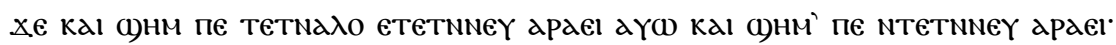

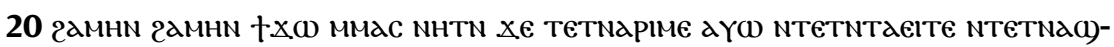

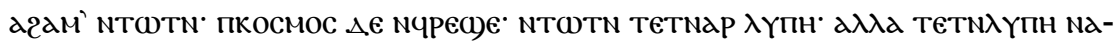

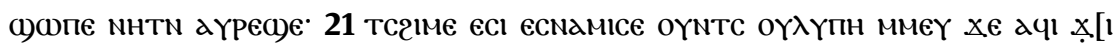

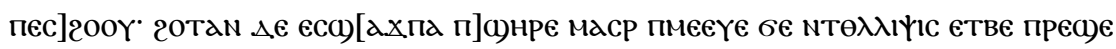

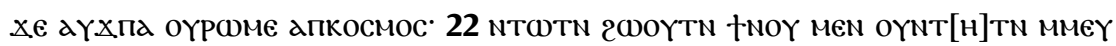

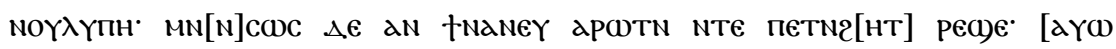

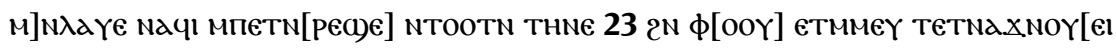

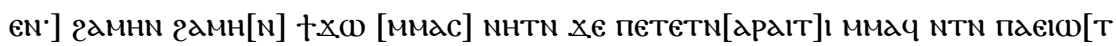

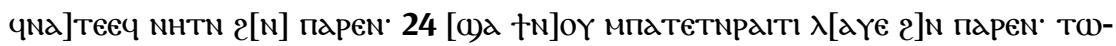

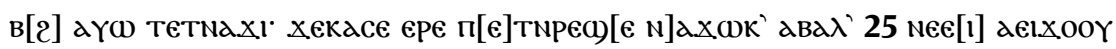

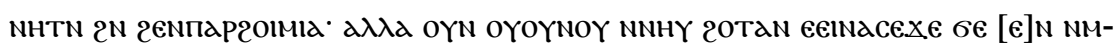

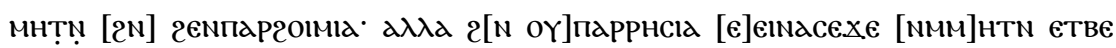

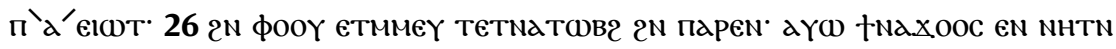

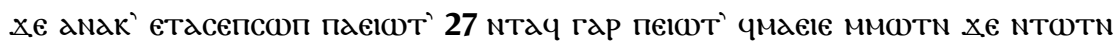

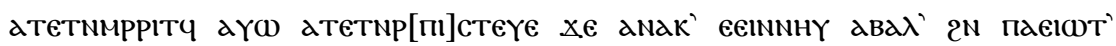

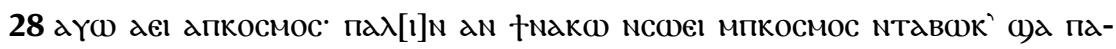

13 2 1 тнмє] sic! Tho. 15 єтеүнте ' c' $^{\prime}$ ] vermutlich keine spätere Einfügung, denn 3 sa. Mss. haben es, viell. vom Schreiber in seiner Vorlage gefunden, doch nur unter Protest eingefügt

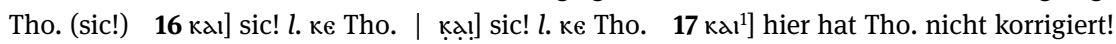

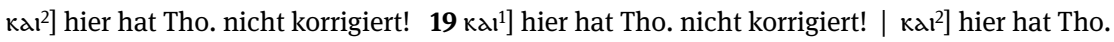
nicht korrigiert! $28 \ldots a \gamma \omega$ ] erster Satzteil von 16,28 ausgelassen wegen Homoioteleutons Tho. | del] sic! für deıє Tho. 


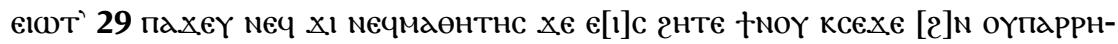
cla aүo nK[X] aүo kpxpla [en $X]$ ]

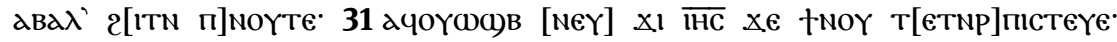

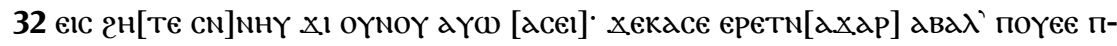

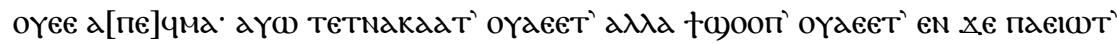

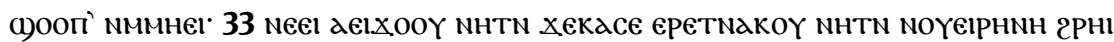

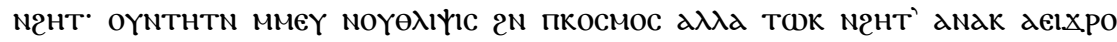
дпкосмос

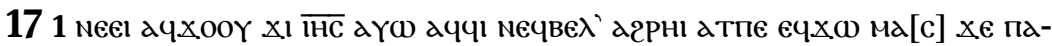

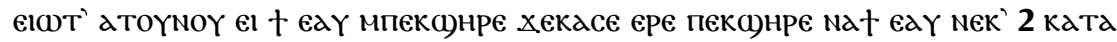

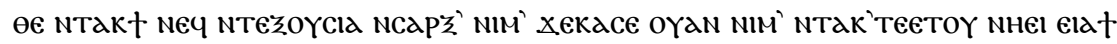

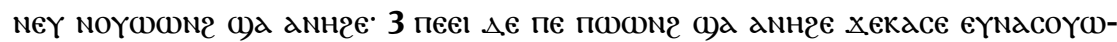

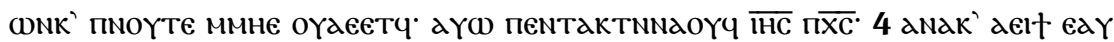

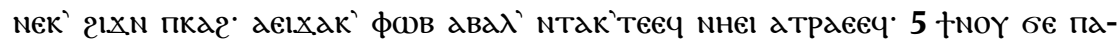

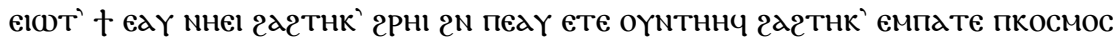

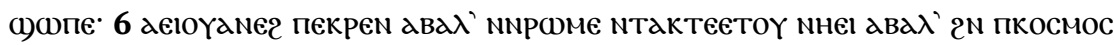

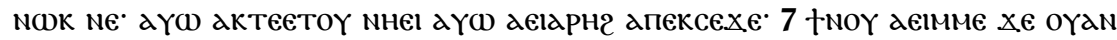

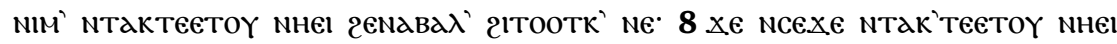

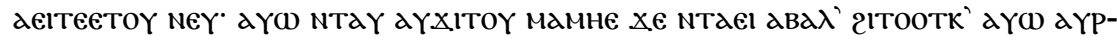

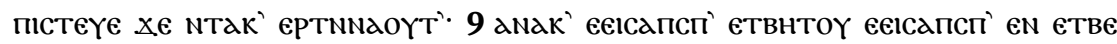

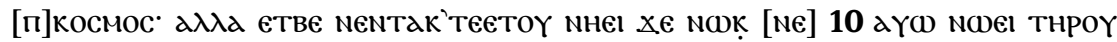

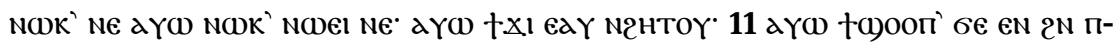

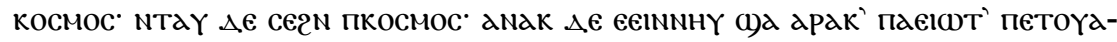

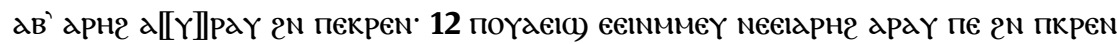

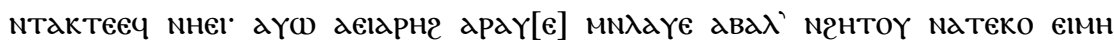

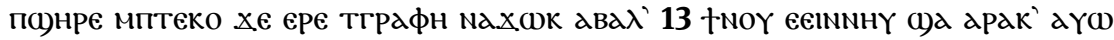

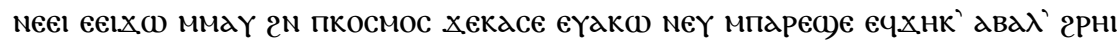

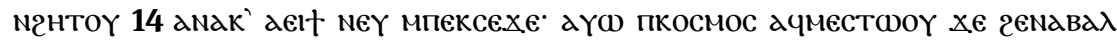

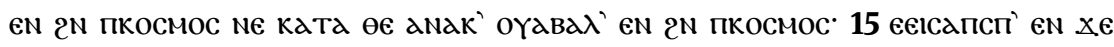

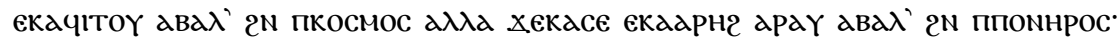

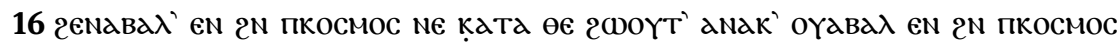

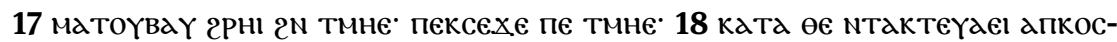

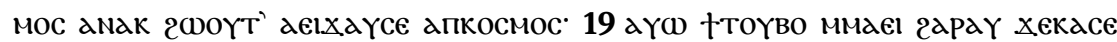

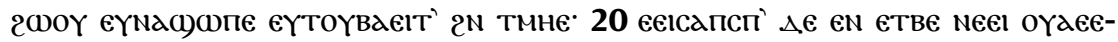

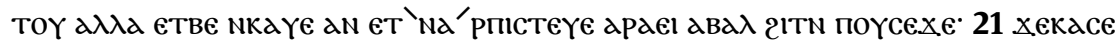

32 еретм[ахар]] хар unsicher Tho. $\quad \mathbf{1 7 , 1} \mathrm{ma}[\mathrm{c}]]$ sic! Tho. 5 оүнтннч] sic! l. оүnтнеiq Tho. 6 деiарнг] sic! Tho. 11 пекрен] letzter Satzteil von 17,11 ausgelassen Tho. 


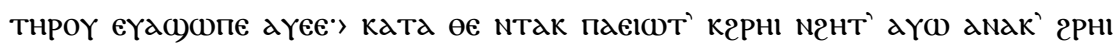

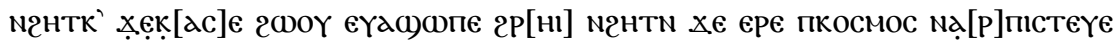

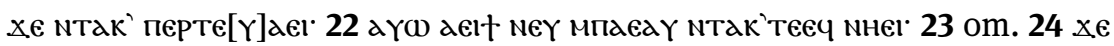

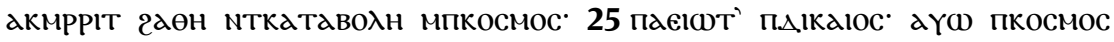

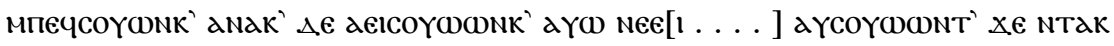

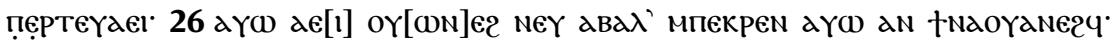
Хекасе тагапн NTакмPрIT ' $\mathrm{N}$ '

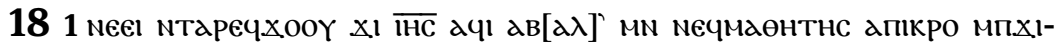

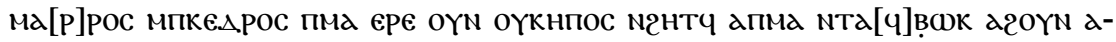

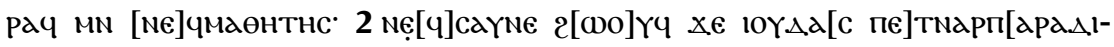
Аo]

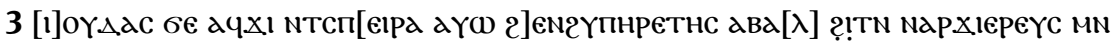

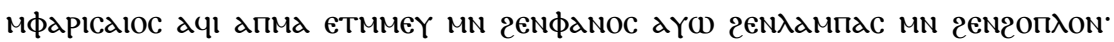

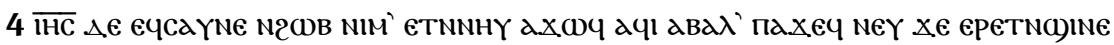

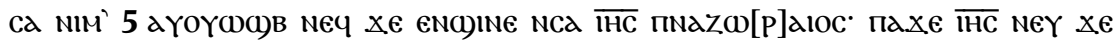

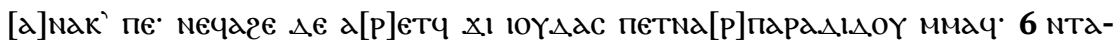

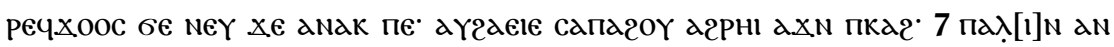

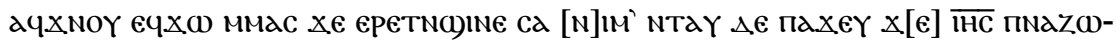

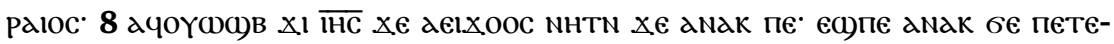

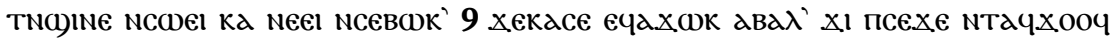

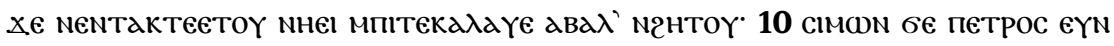

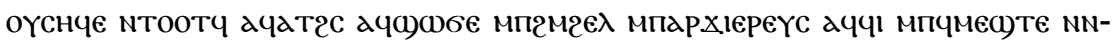

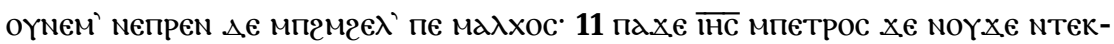

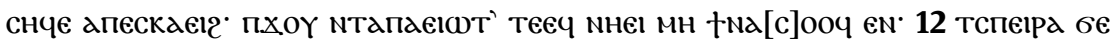

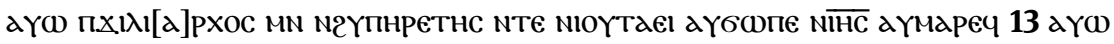

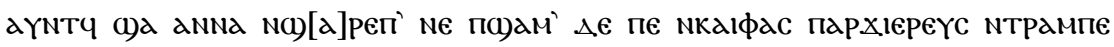

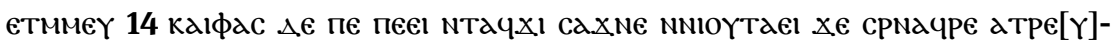

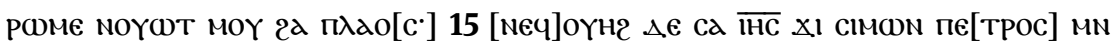

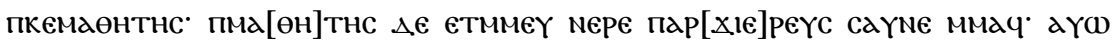

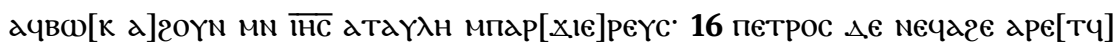

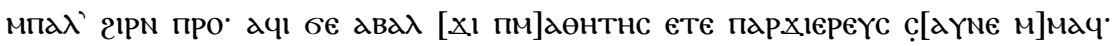

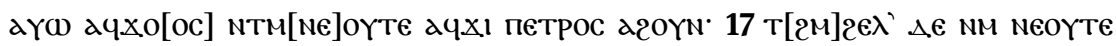

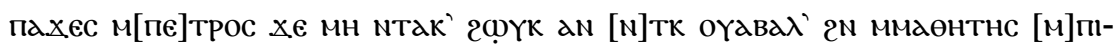

22 NHє1 ...24 хє] Schluss von 17,22, 17,23 komplett und Beginn von 17,24 ausgelassen wegen Homoioteleutons Tho. $25 \mathrm{ne \epsilon}[\ldots]]$ sehr schwache Reste von qoor in der lacuna Tho. 26 мгнтоү] letzter Satzteil von 17,26 ausgelassen Tho. 18,1 мпхıма[р]poc] sic! Tho. 3 nархıє-

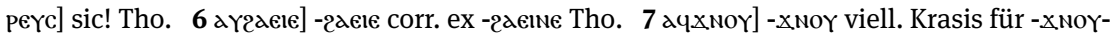

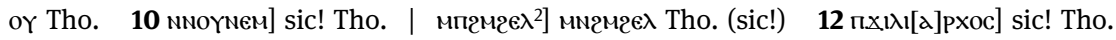

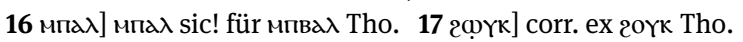




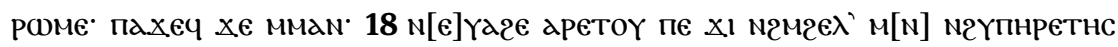

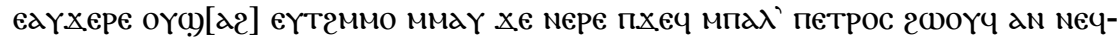

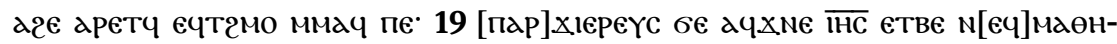

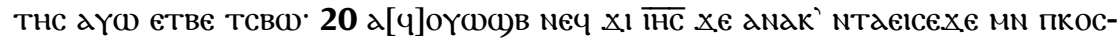

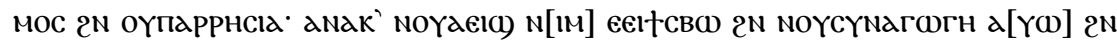

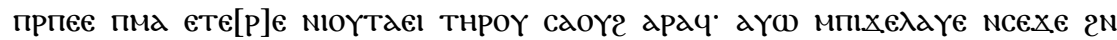

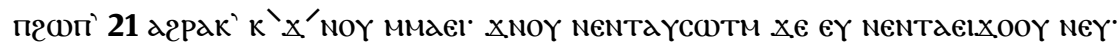

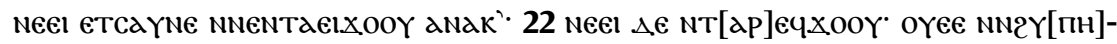

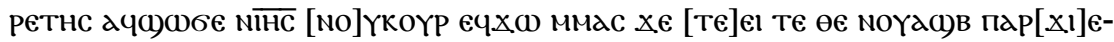

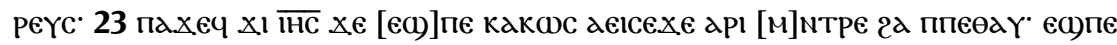

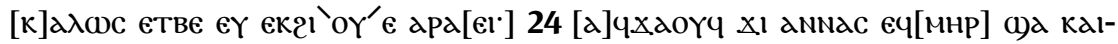

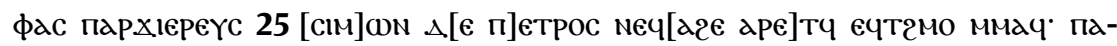

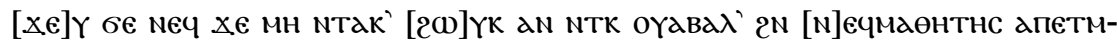
[M]

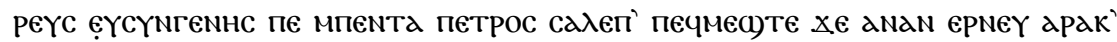

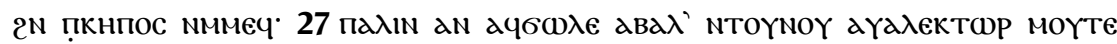

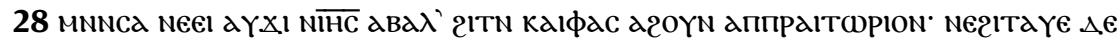

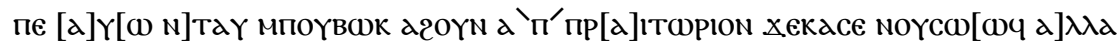
еүNaоүळм мпாа[сха'] 29 [а]

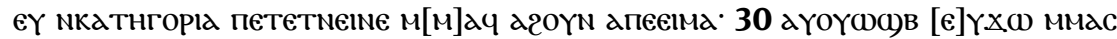

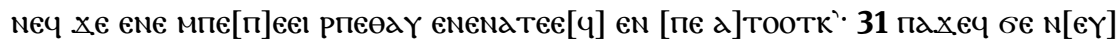

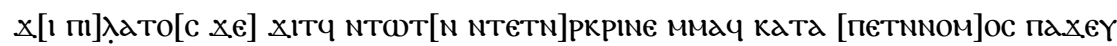

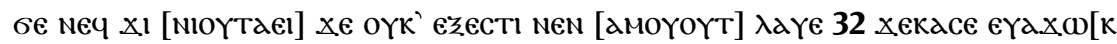

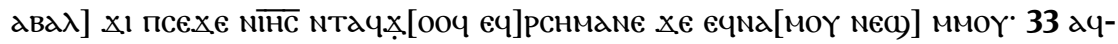

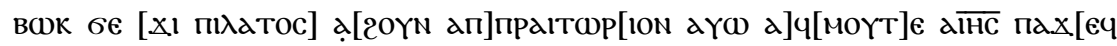

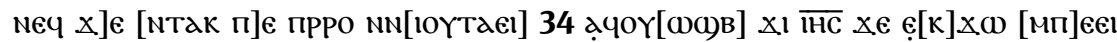

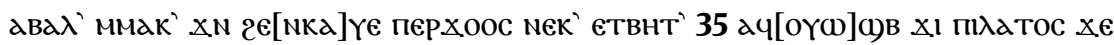

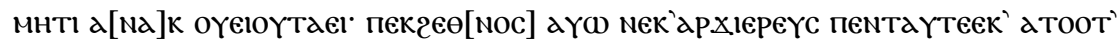

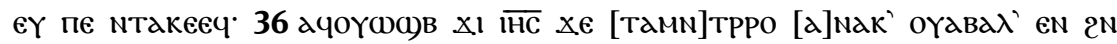

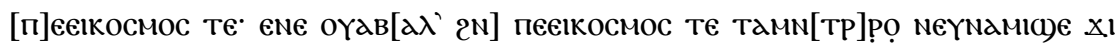

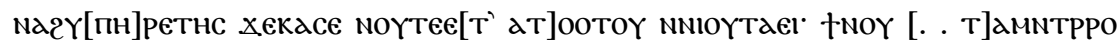

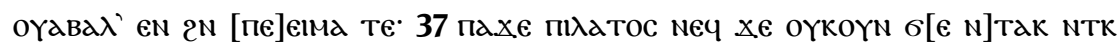

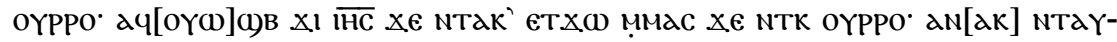

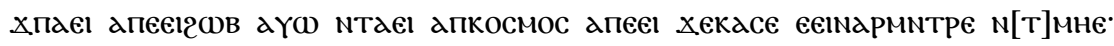

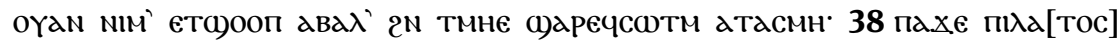

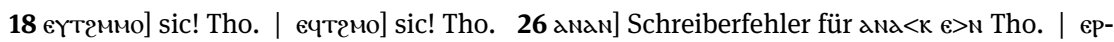
neү] sic! 29 дпееіма'] sic! Tho. 35 оүеiоүтаеl] sic! Tho. | мекархиереүс] sic! l. пекархиереүс Tho. 36 nоүтее[т] nоү- corr. ex емоү- Tho. | [... т]амnтрро] in der lacuna oe vel $\Delta \in$ Tho. $37 \mathrm{NTK}^{2}$ ] sic! Tho. 


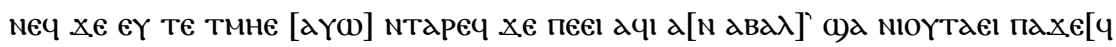
NE]Y Xe aNaK' N†GN $\lambda a Y[E$ E]N NalTIa 2PHI N2HTY 39 [o]YNTHTN MMEY NOY-

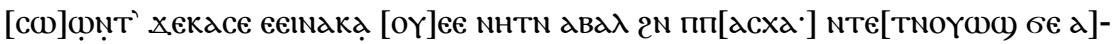

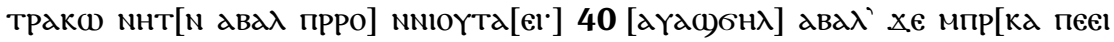

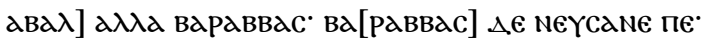

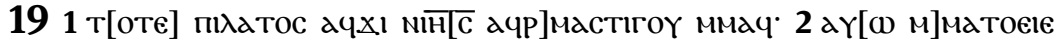

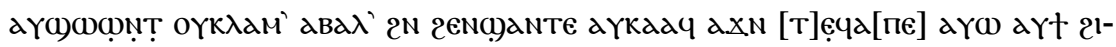

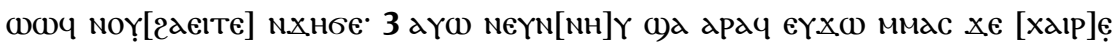

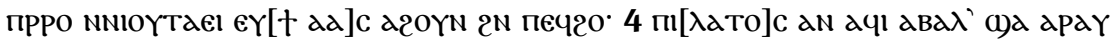

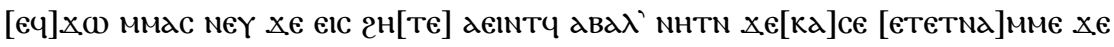

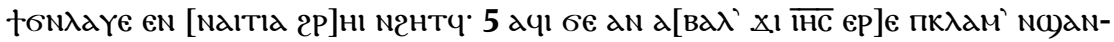

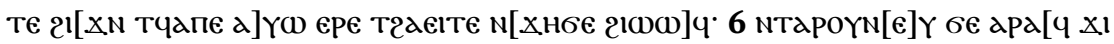

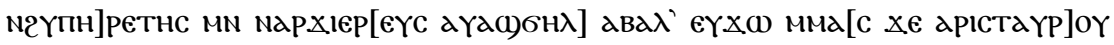

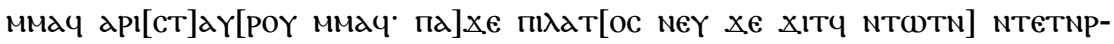

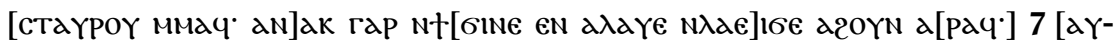

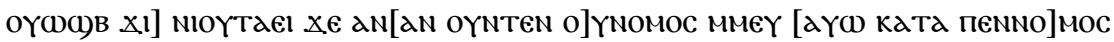

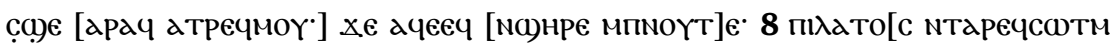

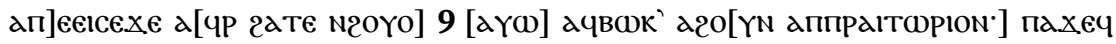

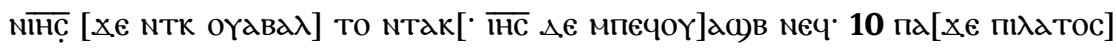

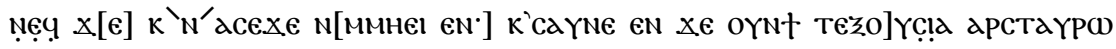

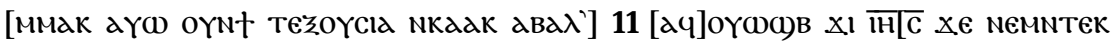

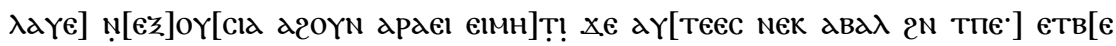

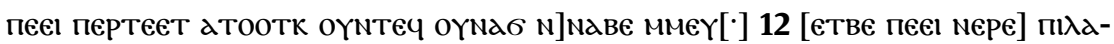

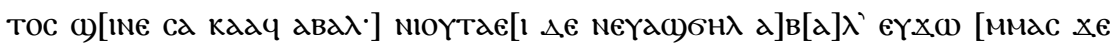

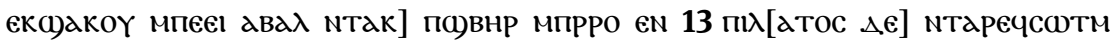

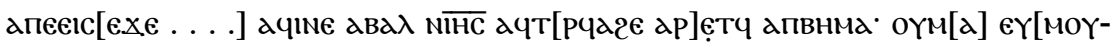

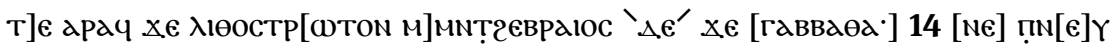

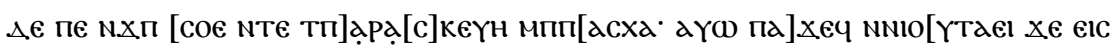

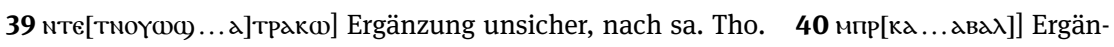
zung in der lacuna unsicher Tho. 19,1 т[оте]] in der lacuna viell. noch $6 \epsilon$ Tho. 2 nợ[2aelте]] [əaeıтe] cf. 5,5 Tho. 3 [xaıp]ẹ] [xalpe] (Anm.: Spur des e ist sichtbar) Tho. | ad]c] c ist sicher, doch die Vokalisierung in diesem Dialekt zweifelhaft; in der lacuna ist Platz für 3

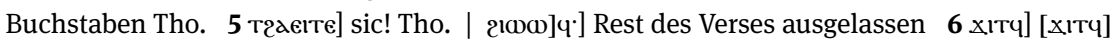

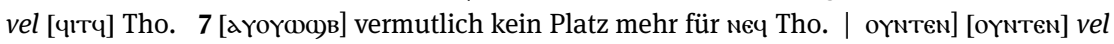

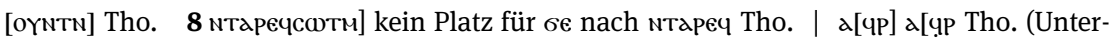

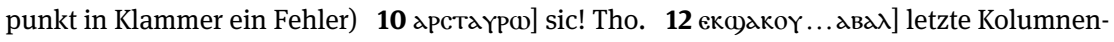
zeile sehr unsicher; zweite Vershälfte wohl ausgelassen wegen Homoioteleutons Tho.

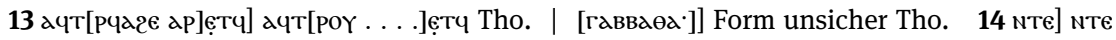

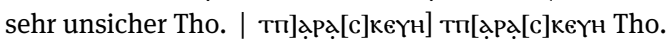




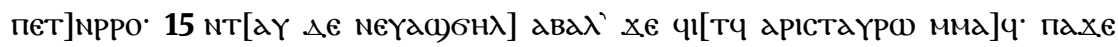

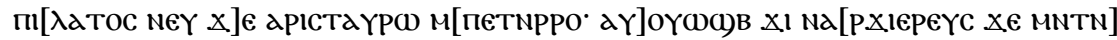

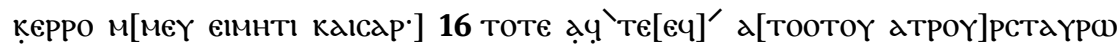

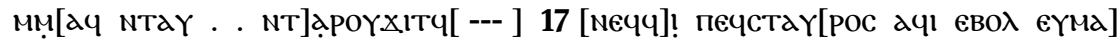

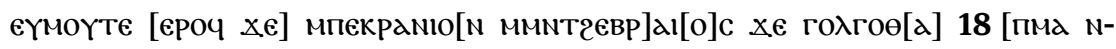

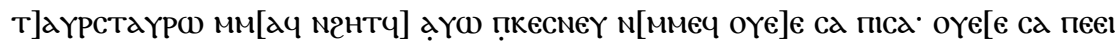
i] рос мечснг $\Delta] \epsilon$ арач $X \in$ пеєІ п[є $\overline{\mathrm{IHC}}$ пNаZ] TIT

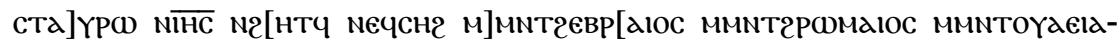

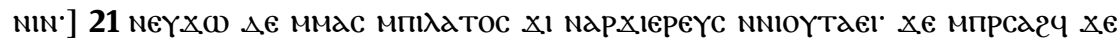

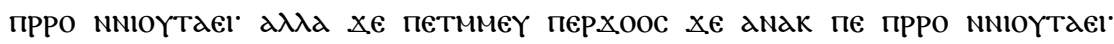

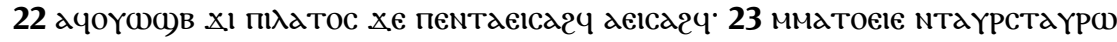

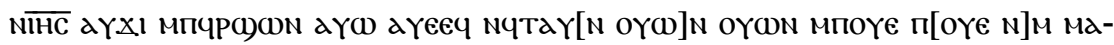

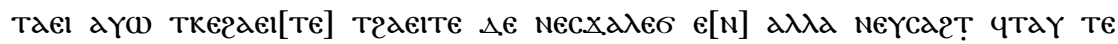

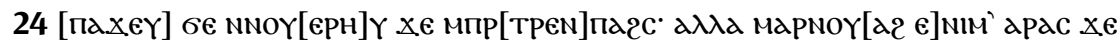
есар та мім' $x$ [eка]се ере тграфн Naх

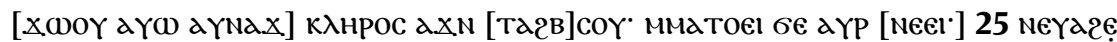

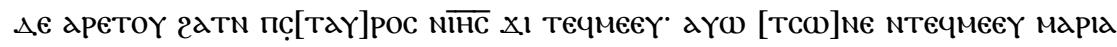

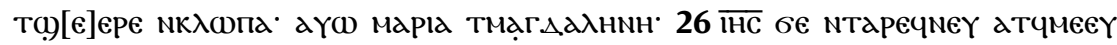

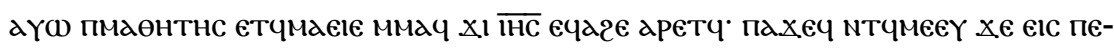
()нре' 27 е[1]та пахеч мпмдентнс $X \in$ ес тек'меєү' XIN фоо етм[м]еY апма-

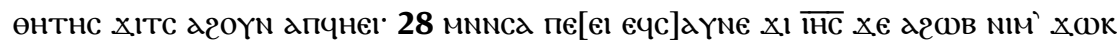

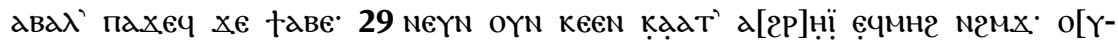

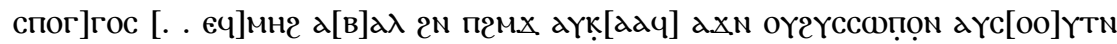

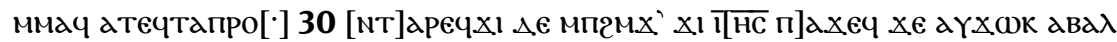

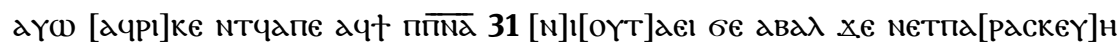

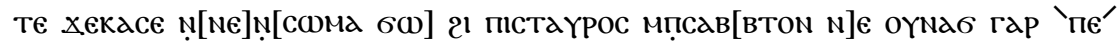

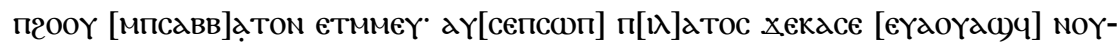

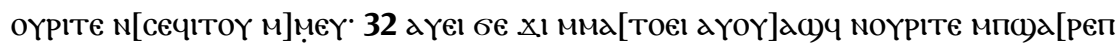

15 чІ[тч] kein Platz für ein 2. чІтч in der lacuna Tho. 16 ạ ' те[єч]'] nach тоте schrieb der Kopist ечдто, tilgte und korrigierte eч zu aч, fügte тєєч oberhalb der Zeile ein und fuhr mit атоото fort Tho. | $а$ [тоотоү] $\alpha$ [тооото Tho. (Unterpunkt in Klammer ein Fehler)

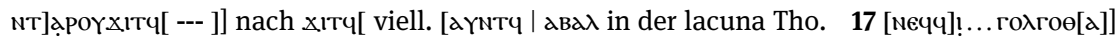
[. . .]! печстаү[рос ... .]еүмоүте[. . .]мпекраміо[м м... .] годгое[ Thо. 20 мг[нтч] danach viell.

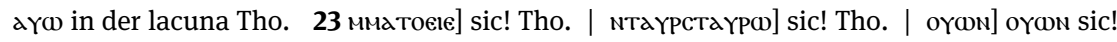

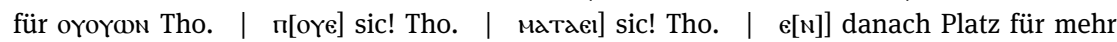

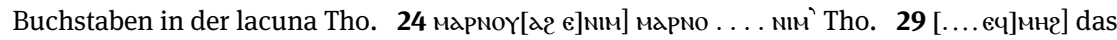
Wort davor war $\sigma \in$ vel $\Delta \in$ Tho. | aүc[oo]үтN] die beiden Vokale in der lacuna sind unsicher Tho. 31 мєтпа[раскеү]н] мєтп入[раскеү]н Tho. | [єүдоүас)ч]] Ergänzung sehr unsicher Tho. 


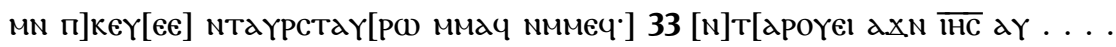

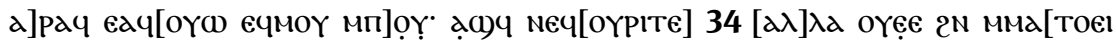

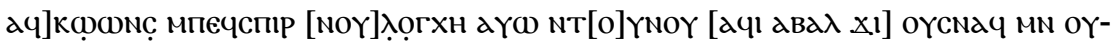

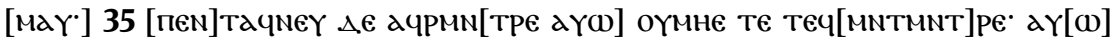

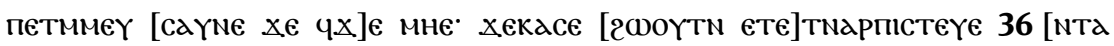
Ne]

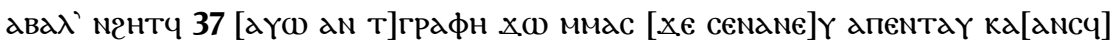

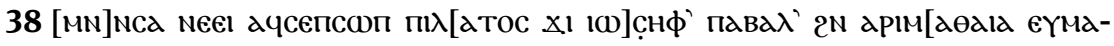

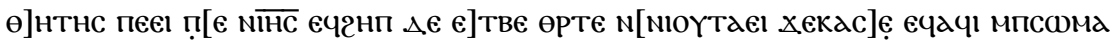

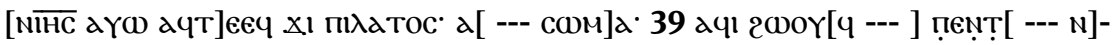

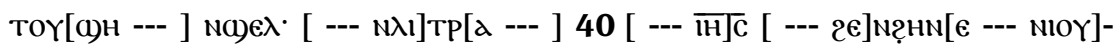
TaE[1 --- ] 41 [ --- ne]оYn [ --- пMa] ета[YPCTaYpo --- ] 42 lac.

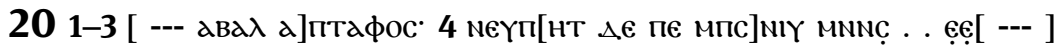

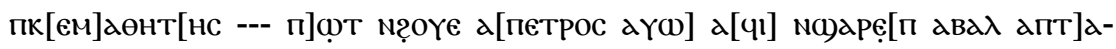

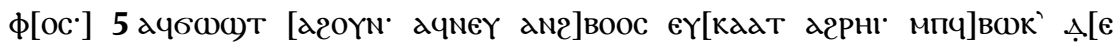

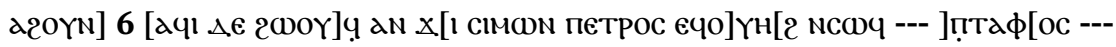

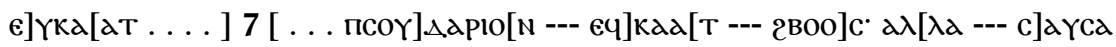

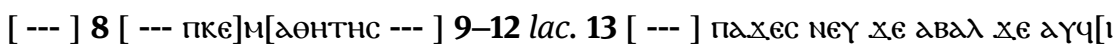

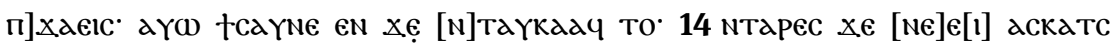

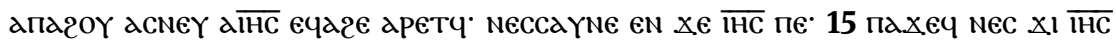

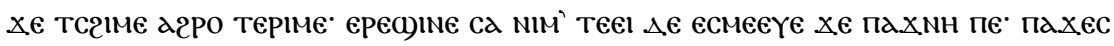

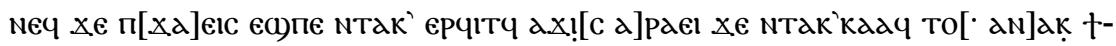

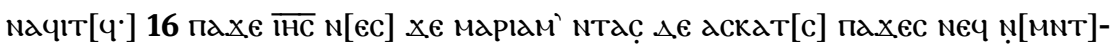

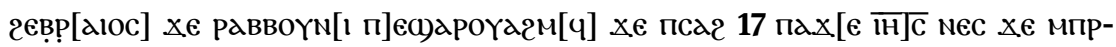

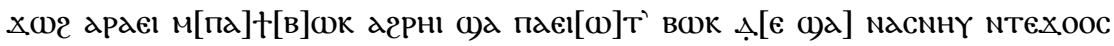

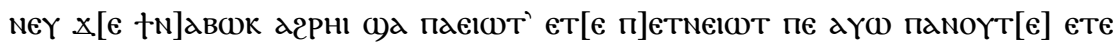

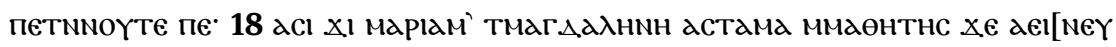

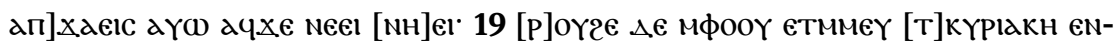

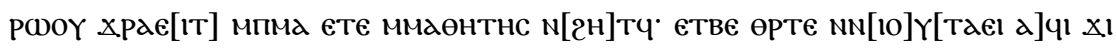

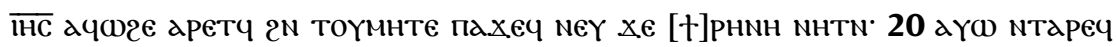

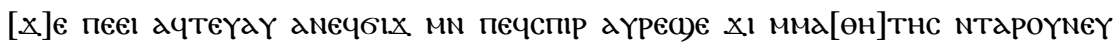

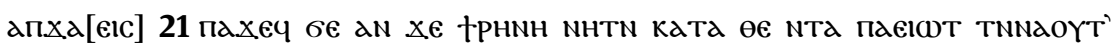

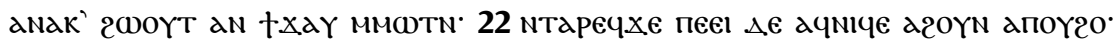

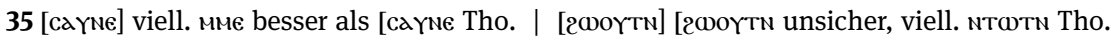
36 [єрє тгр]афн] ерє тг[рафн Tho. (falsche Klammer) | [Nєүкє]c] Ergänzung sehr unsicher Tho. 37 ка[аncq]] Ergänzung sehr unsicher Tho. 38 өрте] cf. 20,19 Tho. 20,4 mnnc... ẹẹ]

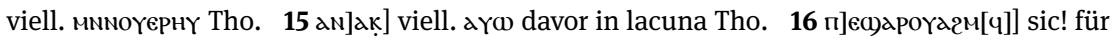
пес)дроүоүагм[ч] Tho. 19 өрте] sic! cf. 19,38 Anm. Tho. 


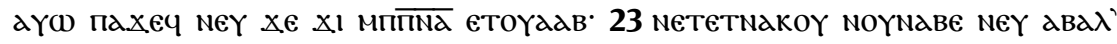

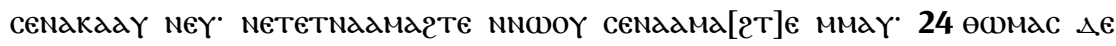

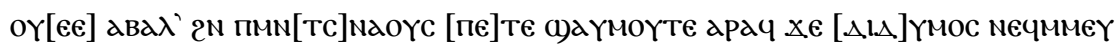

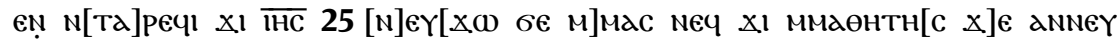

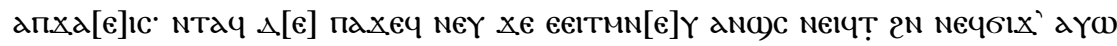

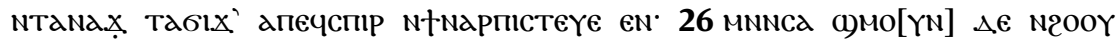

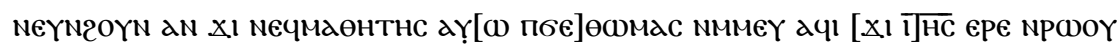

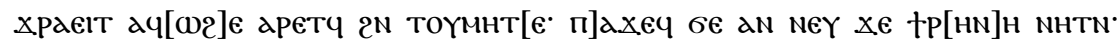

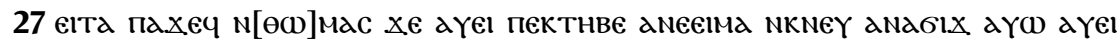
тк6IX nкхас [ап]аспір Nктм0)Фпе [ --- ] 28-31 lac.

\section{1-25 lac.}

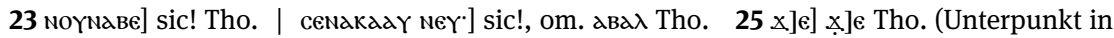

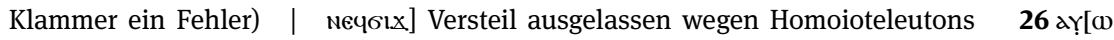

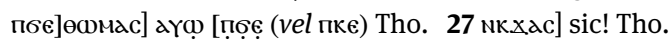

